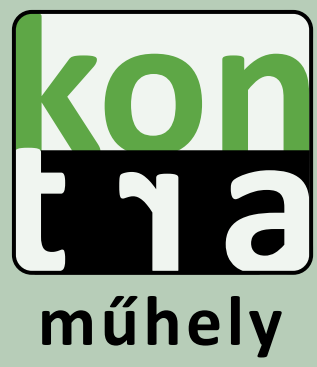

Fiatal múvészek és kutatók multidiszciplináris együttműködése

\title{
A 80-AS GENERÁCIÓ
}

pályakezdő társadalomtudósok esszékötete 
(i) $\$$ 
A 80-as generáció 
Megjelent a Kontra Mủhely gondozásában • 2010 www.kontramuhely.hu

A kötetet szerkesztette: Tarr Ferenc Borító: Jekl Dóra

Tördelés:Tamás László 


\section{Tartalom}

- Alpár Balázs - Langmár Péter - Tarr Ferenc: Előszó

6.

- Alpár Balázs - Langmár Péter - Tarr Ferenc: A Kontra Múhely alapdokumentuma

- Tarr Ferenc: Bevezető esszé

- Kocsis Andrea: A posztadoleszcencia jelensége a kortárs egyetemisták körében

- Korenyák Zsófi - Pataki Teréz: Élménykeresők - a nyolcvanas évek generációjának élmény-megélési stratégiái

- Babócsai Zsuzsa: Érzelemkifejezés és a 80-as generáció

- Szabó Anita: A nemzeti identitás meghatározói az 1980-89 között születettek körében

45.

- Laposa Richárd - Schneider Géza: A külföldre utazás motivációjának vizsgálata a 19-29 éves korosztályban

- László Johanna: A közösségiség és az átmenet generációja hogyan változott meg a közösségiség fogalma a szocializmus felbomlását követően?

60.

- Stalzer Tamara: A családmodell átalakulásának hatása a párkapcsolatokra 68.

- Berecz Dia - Molnár Zsófia - Papp Gergely: A motivációs levélen innen és túl - az 1980-1985 között született „kreatívos”fiatalok a munka világában 74.

- Antal Nikolett: Lemoshatatlan festékek - nem gyógyuló sebek A kortárs művészet poszttraumatikus jelenségei 83. A kötet szerzői 


\section{Előszó}

Kontra Mühely 2009 tavaszán alakult meg azzal a céllal, hogy kapcsolatot teremtsen fiatal társadalomtudósok és művészek között. Célunk egy olyan szellemi közösség kialakítása, ahol fiatal művészek és tudósok együttműködése során kortárs, alapvetően régiós társadalmi problémák és kérdések közös feldolgozására kerül sor. Véleményünk szerint mind a mủvészeteknek, mind a társadalomtudománynak aktuális és gyakorlati kérdésekre kell reflektálniuk ahhoz, hogy valóban segítsék a társadalom felmerülő problémáit kezelni. Úgy véljük, hogy a „magaskultúra” - esztétikai izoláltságából fakadóan - nem adhat adekvát és demokratikus válaszokat a mindennapok kérdéseit érintő témákban, ezért ezen szerepét nem töltheti be sikeresen. Felhasználva a társadalomtudományos eredményeket, az alkotótevékenység egy, a társadalmi szerepvállalás szempontjából aktívabb, hatékonyabb alternatíváját kívánjuk kialakítani.

Ennek szellemében szerveztünk 2009 nyarán egy két hetes alkotótábort a Baranya Megyei Apátvarasdon, a Munka témájának feldolgozására. A tábor mintegy harminc résztvevője előadások és művészeti bemutatók formájában ismerkedett meg egymással, illetve terepmunkán keresztül a környezettel.

Azonos célokkal indítottuk el $A$ 80-as generáció kultúrája és életperspektivaái elnevezésű projektünket, melyet a Fővárosi Önkormányzat „Te jössz!” pályázata támogatott. Felhí- 
vást tettünk közzé pályakezdő társadalomtudósok számára, hogy kutassanak a megadott témában és adják elő eredményeiket egy konferencia keretében. Felhívásunknak fontos eleme volt, hogy társadalomtudósnak tekintett mindenkit, aki a társadalom konkrét, jelenlegi problémáival hivatott foglalkozni. Éppen ezért célunk nem egy tudományos módszertan szempontjából kikezdhetetlen, kutatói konferencia megszervezése volt, inkább egyfajta körképet, önvizsgálatot készíteni arról, hogy miként látja saját generációnk önmagát. Mennyiben tekinthetjük magunkat a korábbiaktól eltérő, motiválatlan, vagy többek által elveszettnek tekintett generációnak? Vajon feltevéseink, a mindennapokból fakadó tapasztalataink mennyiben igazolódnak, ha jobban megvizsgáljuk, illetve megosztjuk egymással őket? Felhívásunk egy kísérlet volt arra nézve, mennyiben érdekes ez a téma és milyen mennyiségben és minőségben mozgatja meg korosztályunkat?

Ennek eredményeként tartottuk meg 2010 októberében három napos konferenciánkat a SíN Kulturális Központban, ahol összesen tizenegy előadást hallgathattak meg a résztvevők. Jelen esszékötet ennek a konferenciának az írásos változata, melyet 2011 januárjában adtunk ki és mutattunk be egy, a témát feldolgozó összművészeti est keretein belül. Fontosnak tartottuk ugyanis, hogy a kutatások és a konferencián folytatott eszmecserék eredményei alkotások formájában is feldolgozásra kerülhessenek, hiszen ez valósítja meg a Kontra Műhely céljául kitűzött kutatói és művészeti együttműködést. A különböző művszeti ágak képviselői közötti diskurzus elősegítését a kezdetektől fogva fontos feladatunknak tekintjük. Kisebb-nagyobb összművészeti projektek elkészítéséhez igyekszünk összefogni fiatal művészeket, akik bemutatkozási és kooperációs-partnerkeresési lehetőséget kapnak időszakos találkozóinkon, rendezvényeinken. Reményeink és tapasztalataink szerint az ilyen találkozókon létrejövő művésztársulások közösségi értékekben gazdag alkotásokat hoznak létre, ebből kifolyólag sikeresebben szólítja meg a célközönséget. Ezen céljának elérésében tovább segíti a művészeket, hogy saját korosztályuk társadalomtudósaitól, szintén közösségi keretek között szerezhet alapozó tudást olyan kérdésekben, amelyek inspirálhatják műveiket.

Az itt olvasható esszék a 2010 októberében megrendezett konferenciánk egy-egy elöadásának feleltethetőek meg. Ennélfogva eltérő minőségű szövegekről van szó, ugyanakkor arra kértünk minden esszéírót, hogy fogalmazzon meg egy hipotézist, melyet kutatása eredményeként cáfolni vagy igazolni igyekszik. Mindezek a megállapítások jelentik azt a körképet, mely ennek az esszékötetnek is valós célja volt.

Tehát ez nem egy tudományos tanulmánykötet, sokkal inkább egy, az alaposság igényével készült, tényeken, vizsgálódásokon alapuló eszmefuttatások sorozata, mely a nyitottság, a párbeszéd elvén alapszik.

Budapest, 2010. december 3. 


\section{$k$ op \\ mühely \\ A mühely alapdokumentuma}

Célunk egy olyan szellemi közösség kialakitása, ahol fiatal müvészek és tudósok multidiszciplináris együttmüködése során kortárs, alapvetöen régiós társadalmi problémák és kérdések közös feldolgozására kerül sor. A háttérben zajló kutatómunka mellett eredményeinket szeretnénk a széles közönség számára érthetö és elérhetö fizikai és szellemi formába önteni olyan új összmüvészeti alkotások rendszeres bemutatásával, amelyek mellözik a fölösleges esztétizálást, az öntörvényü, öncélú alkotói attitüdöket, mert hisszük, hogy a forma és a minöség a befogadóval közösen alakitható ki.

\section{Általános, elméleti alapvetések}

\section{Az alapmotiváció}

Meggyőződésünk, hogy a XXI. század mind a művészeteket, mind a társadalomtudományokat (értsd minden olyan tudomány, amely a társadalom konkrét, jelenlegi problémáival hivatott foglalkozni, illetve a társadalom új kereteinek, kommunikációs formáinak kialakításával foglalkozik) egészen új típusú kihívások elé állítja. A tömegmédia hatásainak térnyerése, a tudomány új vívmányai egyre gyorsuló ütemben tesznek fel újabb és újabb kérdéseket az emberiség számára. Úgy gondoljuk, hogy mind a művészetek, mind a társadalomtudományok egy feltétlen szükséges változás előtt állnak. Ennek a változásnak a lényege egy közvetlenebb kapcsolat kiépítése a társadalommal. Úgy véljük, hogy a művészeteknek az a típusa, amely korábbi paradigmákban létrejött alkotások rekontextualizálásával próbál kortárs lenni, nem lehet alapvető, ahogyan a szakmaiság által diktált, sokszor metatudományos értekezésekben elvesző tudományok sem. Úgy véljük, hogy a magaskultúra, illetve az akadémikus tudományfelfogás - izoláltságukból fakadóan - nem adnak adekvát és demokratikus válaszokat a mindennapok kérdéseit érintő témákban, ezért ezen szerepüket nem tölthetik be sikeresen. Véleményünk szerint a művészet létjogosultságát nem adhatja pusztán a forma tudományos szemléletủ megújítása, a társadalommal sikeresen kommunikálni szándékozó alkotásnak tartalmával és megjelenésével egyaránt meg kell tudni szólítania akár a laikus befogadót is.

\section{Határok lebontása}

Valljuk továbbá, hogy a XXI. század jellemzője, hogy nélkülöz egy domináns, az alapvető értékeket meghatározó értékrendet, eszmerendszert. Ennek következményeképpen az egyéni döntések az életben való eligazodáshoz sokkal nagyobb szerepet kapnak. Ezzel mind az oktatás, mind a társadalom számára mintákat felmutató egyéb tevékenységek, a 
korábbiakhoz képest sokkal nagyobb felelősséggel bírnak. Komplexebb kérdésekre kell válaszokat adni, hiszen a korábbiaknál szabadabban alakul az egyén értékrendje, illetve a közösségi értékek kialakítása is egyre demokratikusabb módon zajlik. Úgy gondoljuk, hogy ezen válaszadásokhoz feltétlen szükséges a multidiszciplinaritás megteremtése, a paralel törekvések összehangolása. A „80-as generáció” pályakezdő tagjaiként olyan szellemi közösség létrehozásán dolgozunk, amely tudatosítva a XXI. század globalizáló, urbánus, multikulturális jellegéből fakadó kihívásokat, a kultúra szerepének, formáinak újragondolására törekszik.

\section{A társadalmi nyilvánosság erősítése}

Munkánk során szeretnénk elválasztani egymástól a magasművészeti és egyéb kutatást azoktól az alkotásoktól, amelyek széles körben szeretnének kommunikálni. Ugyanis nem hiszünk a magaskultúrában jelenleg domináló alapszituáció tarthatóságában, amely a befogadó fél érdeklődésén és utánajárásán alapszik. A háttérben zajló kutató tevékenység mellett az eredményeket a társadalmi nyilvánosság számára is hozzáférhetővé kell tenni. Úgy véljük, a harmadik évezred értékpiacának sokszínűségében határozott rámutatásokra van szükség, amelyeket a kultúra képviselőinek a meglévő intézményrendszertől függetlenül kell kommunikálnia a társadalom felé . Ennek előfeltétele a társadalommal való közvetlenebb kapcsolat, a társadalom mindennapi életében előbukkanó problémák vizsgálata és az azokra való válaszadás. Nem populáris kultúrát kívánunk gyártani. Nem a befogadónak, de a befogadóért akarunk dolgozni. Célunk nem a szórakoztatás, hanem a magánszféra tiszteletben tartását szem előtt tartó elgondolkodtatás, rádöbbentés és vita keltése. Ahhoz azonban, hogy a kultúra ilyen módon történő megteremtése, tolmácsolása lehetségessé váljon, feltétlen szükséges a társadalomtudományokkal való kölcsönös kapcsolat. Hogy az egyedi értelmet nyerjen a globálisan. Hogy a társadalommal való közvetlen kapcsolat okozta témák elnyerjék helyüket a világról való gondolkodásunkban. A XXI. század egyik mottójának tartott „gondolkodj globálisan, cselekedj lokálisan!” gondolatát, mi szeretnénk mintegy megfordítani: „cselekedj lokálisan, gondolkodj globálisan!”

\section{Magyarországi, elméleti alapvetések}

Úgy gondoljuk, hogy a közép-kelet-európai térség és Magyarország bír bizonyos, a világ alapvető problémáitól eltérő, sajátos problémakörrel is. A társadalom mindennapi életének szempontjából jelenleg kulcsfontosságú problémának tartjuk a politika túlzott szerepét a hétköznapokban; a megkövesült, idejétmúlt intézményrendszereket; a familiaritás szerepét a közszolgáltatásokban; valamint az értelmiséget sújtó Nyugatra történő folyamatos agyelszívást. Mivel müködésünket alapvetően Magyarországon képzeljük el, ezért úgy véljük, hogy ezekre a problémákra feltétlen kötelességünk a magunk válaszait megadni. Hisszük, hogy ezekre a problémákra találhatóak egységes, széles körben elfogadható válaszok. Ezzel szeretnénk olyan változásokat generálni a saját generációnkon belül, melyek lehetővé teszik, hogy hosszabb távon elmozdulás történjen ezeken a pontokon. Kulturális és tudományos tevékenységünket szeretnénk mentessé tenni bármiféle pártpolitikai állásfoglalástól. 


\section{Gyakorlati alapvetések}

Ezen elméleti alapvetések mentén képzeljük el tevékenységünket, melyet három alapvető irányban kívánunk kifejteni:

1. A középiskolás korosztály oktatása, látókörének szélesítése, hogy nagyobb tudás birtokában tudják kifejteni véleményüket a fent tárgyalt problémákról (Művészeti Beavató Foglalkozások)

2. Pályakezdő művészek, illetve társadalomtudósok közötti kommunikációs csatornák megteremtése

3. Összművészeti, interdiszciplináris projektek létrehozása és támogatása

\section{Művészeti Beavató Foglalkozások középiskolásoknak}

Úgy véljük, hogy a mai oktatási rendszer tantervének alapja egy alapvetően más értékrendet rögzítő kontextusban született. Az annak kisebb módosításaival életbe léptetett tanterv nem kész az új kihívásokra, jelenségekre. Ez az oktatás színvonalában, a diákok hozzáállásában, a pedagógusok társadalmi megbecsültségében, a munkaerő-piaci aránytalanságokban mind megnyilvánul. A harmadik évezred jelentette végtelen lehetőségek közötti eligazodást, a média hatásának és szerepének kézben tartását, egyáltalán a kitágult horizont okozta bonyolult eligazodást a hagyományos módszerekkel, merev tananyaggal operáló közoktatáscsak kis mértékben segíti. Ezért egyik legfontosabb tevékenységünknek érezzük, hogy a közoktatás tanmenetére épülő, de azt kiegészítő foglalkozássorozatokat tartsunk középiskolákban. Szintén tevékenységünkhöz tartozik nyári táborok szervezése, ahol rövidebb idő alatt, de intenzívebb módon van lehetőségünk hatást kifejteni. Módszertanunk vegyesen épít zene-, film-, szín- és képzőművészeti elemekre, kapcsolatot keres a gyerekek által jól ismert populáris kultúra és a klasszikus gimnáziumi tananyag között, kortárs tömegkommunikációs tendenciák interaktív elemzésével segíti az eligazodást a mai kulturális áradatban. Célunk, hogy kialakítsuk az elemzés és értelmezés képességét, a média termékeinek tudatos és kritikus befogadását.

\section{Pályakezdő művészek, illetve társadalomtudósok közötti együttmüködés elősegítése}

Az új évszázad sokszínűsége, komplexitása egyben azt is jelenti, hogy a világ egyre nehezebben látható át az egyén számára. A tudományok felaprózódása, az életviteli lehetőségek nagy száma különösen megnehezíti, hogy az egyén valamiféle egységes életfilozófiát tudjon kialakítani. Úgy gondoljuk ezért, hogy ennek megkönnyítése érdekében elengedhetetlen a különböző szakterületek közötti párbeszéd és az abból fakadó konklúziók (értsd: nem feltétlen egyértelmű jelentéssel felruházott állítások, mint inkább a vita során ébresztett gondolatok) generálása. Mint a legfiatalabb, aktív életkorba lépő generáció szeretnénk a társadalmi párbeszéd fogalmának egy új jelentést tulajdonítani. Kezdeményezésünk lényege pályakezdő művészek és társadalomtudósok együttműködésének megteremtése. Fontosnak tartjuk ugyanis, hogy a művészek, mint a médiumok szakemberei, bizonyos tájékozódás és maguk számára elfogadható konklúziók megvonása után fejtsék ki tevékenységüket. A társadalomtudósok számára is fontos, hogy megfogalmazzanak olyan gyakorlati iránymutatásokat, amelyek a szakmai közönségen túl mások számára is hasz- 
nosíthatók. Továbbá ezen találkozások hozadéka nemcsak a más gondolatok általi inspirálódás, hanem a közös munka, valamint bizonyos kérdésekben az egységes állásfoglalás lehetősége. Ugyanakkor nem kívánunk semmiféle 'ars poetica'-t, tevékenységünkre vonatkozó szabályrendszert, gondolati struktúrát megfogalmazni. Nem az a célunk, hogy uniformizáljuk a gondolatainkat, hanem, hogy a különböző gondolatok gazdát cseréljenek és elösegítsük azt, hogy az egyén számára bizonyos konklúziók megfogalmazódhassanak. Mindezek keretében tervezzük a valamely aktuális társadalmi problémát célkeresztbe állító előadássorozataink megszervezését, melyek lehetőséget adnak egyéni megnyilatkozásra, vitára, állítások megfogalmazására Ezeket az előadássorozatokat művészeti alkotások, tudományos értekezések létrehozásával kívánjuk lezárni, mintegy az elméletet és a gyakorlatot összekapcsolva. Továbbá tervezzük egy honlap létrehozását, mely virtuális fórumaként szolgálhat a partnerkereséseknek, vitáknak, anyagok közzétételének. Szeretnénk felvenni a kapcsolatot más, hasonló célkitűzésekkel bíró szervezetekkel és velük együtt, egymást segítve dolgozni, illetve szeretnénk kommunikációs csatornákat létrehozni különböző szakterületű egyetemek között.

\section{Összművészeti, interdiszciplináris projektek létrehozása és támogatása}

Tevékenységünk egyik legfőbb célkitüzése, hogy a gyakorlatot szolgálja. Minden elméleti vita, program, alapvetés azt a célt szolgálja, hogy az valamilyen gyakorlati módon testesüljön meg és azon keresztül fejtsen ki hatást. Ezért olyan projektek létrehozása és támogatása a célunk, melyek az elméleti tevékenységünk során felhalmozódó tapasztalatokat formába öntik. Ezeket workshopok, táborok, kurzusok szervezésével szeretnénk elérni, melyek során a generációnknál tapasztaltabb, szakmai előadók meghívását is tervezzük. Különösen fontosnak tartjuk, hogy a hazai viszonyok nemzetközi összehasonlításban is részesüljenek, munkánk helyet kapjon egy globális kontextusban. Ezért hosszú távon és lehetőségeink szerint szeretnénk nemzetközi workshopokat is szervezni. Továbbá szintén hosszú távú terveink között szerepel - annak égető hiányát tapasztalva, - a szakmai segítségnyújtás, azaz jogi, pénzügyi, technikai tanácsadás a különböző pályakezdők számára.

Budapest, 2009 szeptember

A mủhely alapítói:

Alpár Balázs

Langmár Péter

Tarr Ferenc 


\section{Tarr Ferenc:}

\section{A 80-as generáció}

- bevezető esszé -

Az első kérdés, ami bárkiben felmerülhet, aki erről a témáról hall, hogy mit jelent ez a fogalom: „80-as generáció”? Kiket nevezünk egyáltalán 80 -as generációnak? Erre a nyilvánvaló válasz, hogy az 1980 és 1990 között Magyarországon születetteket. ${ }^{1}$ A valós kérdés azonban az, vajon jelent-e ennél többet, túlmutat-e ezen a meghatározáson ez a fogalom? Természetesen mind ennek, mind az ebben a kötetben található esszéknek az adja az alapját, hogy „igen”-nel válaszolnak erre a kérdésre. Mert hát mit is jelent az, hogy valaki 1980 és 1990 között született? Azt, hogy 2010-ben 20 és 30 év közötti, pályakezdő fiatal. A kötet tehát alapvetően azt feszegeti, hogyan látja a rendszervált(oz)ás utáni első generáció a maga helyzetét, lehetőségeit és közvetetten az országot, ahol él.

Két alapvető szempont van, aminek alapján érdemes vizsgálni ezt a korosztályt: a múlthoz és a jelenhez füződő viszonya szempontjából. A múlthoz való viszonya kapcsán azt állapíthatjuk meg, hogy ennek a generációnak már nincsenek közvetlen tapasztalatai a szocializmushoz kapcsolódó világból. Aki 1980-ban született, talán az első három osztályt még a régi rendszerben járta, de ez mindenképp kevés ahhoz, hogy értékítéletében, szocializációjában meghatározó szerepet játszhatott volna a szocializmus. Aki 1989-ben született, lassan alapképzésének végére és ezáltal a munkaerő-piac határára ér. A jelenhez való viszonya kapcsán tehát azt állapíthatjuk meg, ez a generáció most jelenik meg és válik egyre fontosabbá a munkaerö-piacon.

Mindez azt jelenti, hogy ennek a generációnak már lehetősége van a korábbi paradigmától mentesen élni. Lehetősége van attól független értelmezni bizonyos jelenségeket és ezáltal újradefiniálni bizonyos alapokat. Például nem feltétlen kell politikai gondolkodásának egy bipoláris, a közgondolkodásban sokszor megjelenő, a köznyelven „komcsi-nacionalista” tengelynek nevezett rendszer mentén szerveződnie. Ugyanakkor, mint a munkaerőpiacon megjelent legfrissebb korosztály, tőle várható az inspiráció, a rugalmasság, a kreativitás és az intuitív gondolkodás, hiszen még képes az intézményi, a bejáratott szokások uralta rendszeren kívüli gondolkodásra. Működését nem feltétlenül az intézményi keretek befolyásolják, hanem érdeklődése és a progresszivitás. Ugyanakkor éppen a támogatás híján nem képes saját ötleteit megvalósítani. Összefoglalva azt mondhatjuk, ennek a generációnak hatalmas szerepe lehet az innovációban, ha megtalálja a működéséhez szükséges formákat. Kulcsfontosságú tehát, hogy ez a korosztály aktív, cselekvőképes, a közügyek iránt érdeklődő legyen!

\footnotetext{
${ }^{1}$ Jelen esszé és esszékötet nem, a manapság szintén használt Y-generáció megfontolását vette alapul. Annak alapját a számítógép-használat jelenti, mely a mi vizsgálódásunk szempontjából kevéssé játszik szerepet, illetve a korosztály sem feltétlen azonos. Azt egy fiatalabb generációnak tekinthetjük.
} 
A 80-as generáció aktivitásának ugyanakkor alapfeltétele, hogy bizonyos problémákkal tisztába kerüljön és válaszai legyenek rá. Azonban szét kell választanunk az életkorból és a történelmi korból fakadó nehézségeket. Nyilvánvaló életkori nehézség egyeztetni az ambíciókat a realitással. Ezzel párhuzamosan hivatástudatra lelni, motivációt találni, felnőtt identitást kialakítani, valamint mindezt összekapcsolni a sikeres magán- és közösségi élettel. Az ehhez kapcsolódó jelenségeket nem szabad tehát a korra kenni, hogy „hát ilyen világban élünk". Ezek a kihívások mindig is nehézséget jelentettek. Annyi azonban megállapítható, hogy az erre az életkorra jellemző problémák, egyre több embernél, egyre elnyúltabban megfigyelhetőek. Azaz mintha a 20-tól mondjuk 35-ig terjedő korosztály „egy cipőben járna”. Hogy ez miben nyilvánul meg? A szociológia nem győzi gyártani a fogalmakat a szülőkhöz visszaköltöző, tőlük függetlenedni képtelen fiatalokról. Az olyan fogalmak, mint gyernőtt, bumeránggyerek, Pán Péter-szindróma, ösdiák, Erasmus-szindróma mind azt a jelenséget írják le, amikor fiatalok nem képesek szembenézni a felnőtté válás nehézségeivel és alapvetően a felelőtlen magatartás, a rövid távú célokat szolgáló cselekedetek dominálnak. ${ }^{2}$ Hiszen általános jelenséggé vált például az egyetemet évtizeden át végző vagy azt félbehagyó diák története, akinek aztán komoly nehézséget okoz az eltékozolt államilag finanszírozott féléveket valahogy pótolni, korrigálni. Mindennek számtalan gazdasági, morális és szociális következménye van. Nem csoda például, hogy „manapság minden a kapcsolatokról szól”, hiszen mi mást kezdhetnének ezek a diákok, mint ismerősön keresztül próbálnak meg egzisztenciát teremteni, ha már a szakmájuk által nem tudnak. És most csak egy példát vettünk önkényesen alapul, annak is csak az egyik súlyos következményét véve szemügyre és akkor még nem beszéltünk a huszonévesek alkoholproblémáiról, növekvő agressziójáról, megváltozott kultúrafogyasztásáról. ${ }^{3}$ Mindezen jelenségek és azok számtalan következményei felfejtésére azonban e bevezetőben most nincs lehetőség.

Gondolhatnánk, hogy ez pusztán a világ negatív szemléletéből és az önkényes példaválasztásból fakad, azonban mindezek a jelenségek már a statisztikákban is megjelennek. Csak példaképpen: a 25-34 év közötti magyar nők 27,2 \%-a, a férfiak 42,5\%-a lakik a szüleivel. ${ }^{4}$ 1993-ban a végzősök 98\%-a szerzett diplomát, míg 2008-ban 54\%. ${ }^{5}$ 2010-re a felsőoktatásban résztvevő hallgatók száma a közel három és félszeresére (108-ról 370 ezerre) nőtt, míg az oklevelet szerzők száma csak a kétszeresére ( 24 ezerről 52 ezerre), miközben a 90-es évek elején egy demográfiai hullám teteje volt a jellemzö. ${ }^{6} \mathrm{~A}$ felvettek aránya a felsőoktatásba 2008-ban 84\% (nappali tagozatra 77,8\%, 2009: 67,4\%, míg 1990: 36\%), míg 1990-ben a jelentkezettek 36\%-át vették fel nappali tagozatra. ${ }^{7}$ A felsőfokú végzettséggel rendelkezők foglalkoztatottsági rátája Magyarországon, nemzetközi összehasonlításban

\footnotetext{
${ }^{2}$ Ehhez l. Családi pótlék In: HVG, 2010. 41. szám

${ }^{3}$ Ehhel l. Aggasztó méreteket ölt a fiatalok alkoholfogyasztása In: hvg.hu, 2007. március 12.

${ }^{4}$ Eurostat-eredmények. 1. Uniós mamahotellakók In: HVG, 2010. 41. szám

${ }^{5} \mathrm{KSH}$ : Felsőoktatás és felsóoktatási kutatás 2003 - 1. http://portal.ksh.hu/pls/ksh/docs/hun/xftp/idoszaki/oktkut/oktkut03.pdf

${ }^{6}$ KSH stADAT-tábla, Oktatás (1960-2009) http://portal.ksh.hu/pls/ksh/docs/hun/xstadat/xstadat_eves/i_zoi007a.html, ill. http://portal.ksh.hu/pls/ksh/docs/hun/xstadat/xstadat_eves/i_wdsi002c.html

${ }^{7}$ KSH stADAT-tábla, Oktatás (1960-2009) (http://portal.ksh.hu/pls/ksh/docs/hun/xstadat/xstadat_eves/i_zoi006.html)
} 
2007-ben az egyik legalacsonyabb volt (80,4\%), öt százalékponttal az EU-átlag alatt, míg a legmagasabb arányt Litvániában (89,4\%) és Svédországban (88,5\%) érték el. ${ }^{8}$ A 25-64 évesek 9\%-a vesz részt oktatásban, képzésben. Ezzel az utolsó az EU-ban, ahol 36\% az átlag. Nem formális képzésben és oktatásban (értsd: konferencia, kurzus, stb.) sem vesznek részt többen, itt 6,8\% a szám (EU-átlag: 33\%). ${ }^{9}$ Mindezekből a statisztikai adatokból azt láthatjuk, hogy egyre többen járnak egyetemre, ugyanakkor arányaiban egyre kevesebben végeznek. Ráadásul a végzettek között is nagyon alacsony a foglalkoztatási ráta, de ennek ellenére az emberek többsége nem képezi tovább magát az egyetem után sem. Magyarán azt mondhatjuk, hogy az egyetemi évek minden szempontból meghatározóak az életünkre nézve, ezek az évek mégis alapvető problémákat mutatnak. Az onnan kikerült diákok többsége motiválatlan, rosszul képzett, elégedetlen, aminek iszonyatos következményei vannak hosszú távon. Miért van ez?

Egyre többen kezdik megfogalmazni manapság, - mind szakemberek, mind laikusok, - hogy egyfajta értékválságban élünk. Megfogalmazás kérdése, hogy ezt válságnak tekintjük-e vagy pedig úgy állunk hozzá, mi nem vagyunk képesek ezzel a szabadsággal mit kezdeni. Mindenesetre az ténynek tűnik, hogy a XXI. század eleje egy olyan világ, ahol az embereknek folyamatosan számos választási lehetősége adódik és ennélfogva konstansan döntéshelyzeteknek van kitéve, ahol többnyire nincs minta, a köz által megerősített értékrend, amely segítené ezeknek a helyzeteknek a kezelését. Ennek köszönhetően szubkultúrákból fakadó értékrendek élnek egymás mellett, melyek a tömegmédia közvetítésével próbálnak modellként funkcionálni, szorosan összekapcsolódva a hozzá tartozó fogyasztás eszméjével. Ez a globalizációval párhuzamosan egyfajta feldarabolódását is jelenti a korábban domináns, alapvetően nemzeti kultúráknak. Azt mondhatjuk tehát, sem a világban, sem Magyarországon nem létezik egy normatívként megnevezhető, koherenciát teremtő értékrendszer, mely mentén - vagy éppen ellene, - igazodni lehetne.

Ennek kapcsán fontos kitérnünk arra, hogy az általunk vizsgált jelenségben egyaránt szerepet játszanak bizonyos globális folyamatok és magyar -, esetleg kelet-európai - specifikumok is. Az előbbinek adtuk rövid összefoglalását az elöző bekezdésben, míg ez utóbbit elsősorban a rendszervált(oz)ás jelenségével és annak következményeivel írhatnánk le. Ezt azért különösen fontos szem elött tartani, mert a két jelenségvilág egyszerre, párhuzamosan van jelen és határozza meg a magyar társadalmat és benne a 80-as generációt is. Mindennek három, általam fontosnak tartott jelenségét emelem ki.

1989-ben a szocilista államhatalom elbukásával egy ideológiai keret is megszűnt. Megszűnt egy, a társadalmi diskurzus alapját képező közeg, mely talán legjobban a kultúrában érhető tetten. Itt a korábbi rendszerben egyfajta „összekacsintás” volt jellemző bizonyos al kotók és társadalom között, amely közös platformra helyezte őket a hatalommal szemben. Ez az ország egy láthatatlan közösségét, egy a társadalmat meghatározó párbeszéd alapját teremtette meg. Ennek megszűnésével nemcsak a „sorsközösség” átélésének élménye veszett el, hanem egy fontos identitásformáló elem is, mely nagyban érintette a magyarságél-

\footnotetext{
${ }^{8}$ Statisztikai Tükör III. évfolyam 15. szám, http://portal.ksh.hu/pls/ksh/docs/hun/xftp/gyor/jel/jel30812.pdf

${ }^{9}$ Statisztikai Tükör IV. évfolyam 87. szám, http://portal.ksh.hu/pls/ksh/docs/hun/xftp/stattukor/felnottkepzes0507.pdf
} 
ményt, mint identitásképző erőt is. Ennek köszönhetően mára a nemzeti ünnepek kiüresedtek, nem töltődtek meg új tartalommal, nem tudtak önmagukból fakadóan jelentést kialakítani. A mai politikai jobb oldal a maga ikonjait, jelképeit elsősorban a 20-as, 30-as évekből meríti, amivel szemben a bal oldal sem tud autentikus identitásképző elemeket, ünnepeket, ikonokat felmutatni. Mindez azt is jelenti, hogy a mai huszonévesek szülei egy egészen más korban szocializálódtak. Az ő életútjuk nem tud modellként szolgálni, nem példaértékü, hiszen a keretek teljesen megváltoztak és nem is tudnak hitelesen reagálni az új jelenségekre. Nehezen birkóznak meg az Internet, a szubkultúrák, a szabad lehetőségek világával. Ezért sok szempontból példaképként sem szolgálhatnak. Felmerül a kérdés, akkor honnan merítik a huszonévesek a maguk példaképeit, modelljeit?

Az bizton állítható, hogy a 80 -as generáció szocializációját nagyban meghatározzák a szubkultúrák. A legtöbben meg tudják mondani, hogy „deszkás”, „metálos”, „hippi” vagy éppen más, általában zenéhez kapcsolódó szubkultúra képviselői voltak-e tinédzser korukban. Talán ennyiből is látszik, hogy egy-egy ilyen szubkultúra számos területre kihat, mint például a zenehallgatási szokásokra, az öltözködésre, az ehhez társuló kellékekre és még számos egyéb dologra. Csupa olyasmire, amelyek megvehetőek és ezáltal piacot képeznek. A tömegmédia feladata elsősorban ezeknek a piacoknak a fenntartása és kiszolgálása, hiszen ezen keresztül tartja fenn magát. Ami szükségszerűen kizárja, hogy morális értelemben vett értékeket közvetítsen, hiszen a legfőbb célja az eladás. Tehát bár úgy tűnik, ezek a médián keresztül közvetített szubkultúrák (élet)modelleket, példaképeket mutatnak fel, valójában nem képesek erre a funkcióra. Gondolhatnánk, hogy a modellek, a motiváció tehát más szocializációs tereken valósul meg, mint amilyenek például az oktatás színterei, azonban a tapasztalatunk nem ezt igazolja.

Azt állapíthatjuk meg, hogy az oktatás intézményei egy olyan régi rendszer elvei szerint működnek, amelyek teljesen képtelenek a jelen kihívásaira reagálni. Erre vonatkozóan érdemes utalni az említett statisztikáinkra, ami azt mutatja, az egyetemek és a munkaeröpiac egyáltalán nincsenek kapcsolatban egymással. Egy régi, akadémikus, lexikális alapú, kizárólagos tudás-felfogáson alapuló intézményrendszer próbál munkaerőt képezni egy fluktuáló, gyorsan változó, kompetencia-alapú piacra. Mindez ugyanígy számon kérhető a közoktatás rendszerétől is, ahol a megtanított tudás lexikális alapú, melynek elenyészően kicsi részére van szükségünk a későbbi életünk, a manapság hangoztatott „LLL”, azaz „Life Long Learning” folyamán. Azt mondhatjuk, hogy az, amit tanulunk, amivel tanulóéveink, időnk jelentős részét töltjük, köszönőviszonyban sincs azzal, amit nap mint nap tapasztalunk. Ennek egyik súlyos következménye, hogy egyfajta bizalomvesztés alakul ki ezen intézményekkel és közvetetten talán az egész intézményességgel szemben is. Másik súlyos következménye egy inaktív társadalom kialakulása, amelyik a tanulást, mint az élet természetes részét képezo „szükségszerű rossz”-at fogja fel, ami egyáltalán nem segít a mindennapi problémák kezelésében, megoldásában. Ma már teljesen jellemzőnek mondható az a gondolkodás, hogy valaki az iskolán kívüli tevékenységét tartja igazi és hasznos tevékenységének, foglalkozásának. Mindez egyáltalán nem segíti, hogy a 80-as generáció a maga modelljeit az tanulóévek során alakíthassa ki vagy egyáltalán valamiféle hivatástudata alakuljon ki a tanulás során.

Mindhárom, általam kiemelt jelenségnek - tehát a szocilista keret felbomlásából fakadó 
következményeknek, a kapitalizmuson alapuló tömegmédia szerepének, az intézményi rendszerek nem-működésének - az a közös tulajdonsága, hogy nem szolgálnak mintául, nem mutatnak fel egy bejárt, értékadó, modellként érvényes utat. Emiatt a 80-as generáció számára a sok út, a rengeteg választási lehetőség és ebből fakadóan a folyamatos döntéshelyzet az adott. Mint erre korábban utaltam, ezt lehet értékhiányos kornak felfogni, ugyanakkor meg is lehet fordítani ezt a jelenséget és azt mondani, az egyéni szabadság korában élünk. Ezen mindenképp érdemes elgondolkodni, hiszen Magyarország történetében véleményem szerint ez egy egyedülálló időszak! Korábban nem volt példa olyan korszakra, ahol az egyéni döntéseknek, értékítéleteknek ilyen nagy és komoly szerep jutott volna az életvitelünk szempontjából.

Ugyanakkor mint minden új korszak esetében, úgy jelen esetben is meg kell tanulni annak szabályait, élni az azok adta lehetőségekkel. Véleményem szerint ez jelen esetben a felelősségvállalás és következetesség szerepének a megtanulását jelenti. Egy, a lehetőségek adta korban meg kell tanulnunk vállalni a döntéseinket és azokhoz következetesnek maradni. Hiszen éppen ez adhatja meg azt a tartást, értéket, azt az egyéni normát magunknak, amit sokan egy külső ideológiától várnak el. Ez természetesen rettenetesen nehéz feladat, hiszen sokszor nem is látszódik ez ilyen világosan, de éppen ezért fontos tudni azt, bármennyire is úgy tünik, a 80 -as generáció motiválatlan, elveszett, ez csak akkor igaz, ha nem tudunk az új kor adta lehetőségekkel, azaz saját szabadságunkkal mit kezdeni! Ennek érdekében pedig nem lehet mást mondani, minthogy nyitottnak, kommunikáció-késznek kell maradni. Ennek a gondolatkörnek a szellemében született meg ez az esszékötet is. 


\title{
A posztadoleszcencia jelensége a kortárs egyetemisták körében
}

\author{
„Mikor véget érnek az alibiévek, \\ és a súlyok nönek a válladon, \\ te röpülnél, de örülsz annak, \\ ha valahogy megállsz a lábadon."
}

(Quimby)

\subsection{Bevezetés}

Tanulmányomban felvázolnám a posztadoleszcencia szociológiai elméletét, a felnőttkor pszichológiai és szociológiai definícióit, majd a Vaskovics László által megállapított dimenziókon át (jogi értelemben vett, közös fedél alól történő, anyagi - pénzügyi, önálló döntést eredményező és szubjektív leválás) vizsgálnám a kortárs egyetemisták/főiskolások csoportját a szülői háztól való függetlenedés folyamatának szemszögéből.

Több mintavételt is végeztek az évek során, melyek érintőlegesen a témába esnek, legaktuálisabbnak az Ifjúság $2004^{1}$ nagymintás kutatás tekinthető, melyet az egyetemistákra Kabai Imre képezett le. Emiatt az eredményeimet diakrón metszetben is lehetne vizsgálni, ellenben az én célom egy problémafeltáró, szinkrón áttekintést nyújtani. Hisz - habár van, aki a posztadoleszcenciát tudományos közhelynek tekinti, és van, aki elismeri, ám lényegtelennek találja - mégis a kortárs fiatalok meghatározó jellemzőjeként kezelem, és ezzel a tanulmánnyal a figyelmet kívánom a kérdés felé fordítani.

Egyetértek Kabai Imrével, aki szerint a „posztadoleszcencia előhírnökei bizonyos értelemben a fóllású hallgatók” (Kabai, 2007, 152), így empirikus vizsgálatomban csak a felsőoktatásban jelenleg résztvevő vagy frissen diplomázott, illetve a „visszaeso”” diákokkal foglalkoztam, tehát figyelmemen kívül estek a más végzettséggel rendelkező fiatalok. Hiszen a fiatalkor kitolódásának leglényegesebb oka - kölcsönösen visszafelé is igaz - az iskoláztatás elhúzódása. Hangsúlyozandó, hogy a posztadoleszcencia nem korosztályi sajátosság, tehát a válaszadóim a kései hetvenes és a korai kilencvenesek születésűek között helyezkednek el életkorban, mégis a kutatásom gerincét a nyolcvanas generáció adja. Összetételüket nagyban determinálja értelmiségi mivoltuk: kérdőívem 176 válaszadója főként egyetemet végzett, szellemi munkakörben dolgozó szülőktől származik, 77\%-ban 
fôvárosi születésű, nagy részben budapesti tanuló (de a vidéki egyetemek is reprezentálják magukat). A tanulmányaikat tekintve viszont heterogénnek mondhatóak, minden képzési területet és a bolognai folyamat összes lépcsőjét lefedik.

Az eredmények bemutatása előtt viszont közelítsük meg elméleti irányból a posztadoleszcenciát.

\subsection{A posztadoleszcencia jelentése és kutatása}

A kamaszkor és a felnőttkor közé beékelődő szakaszt tekintjük posztadoleszcens életszakasznak. Ha beszélünk róla, akkor tulajdonképpen a szülői háztól való leválás folyamatával foglalkozunk. A posztadoleszcencia szociológiailag vitatott, nehezen vizsgálható téma. A társadalomtudósok hosszú időn át homogénnek tekintették a fiatalkort, mígnem a hatvanas évek végén felfigyeltek olyan jelenségekre, amelyek ennek újragondolására sarkallták őket (pl. diáklázadások). Az első stáció, ami feltűnt a kutatóknak az a szexuális érettség és az anyagi önállóság ollójának kinyílása volt (Vaskovics, 2000). Ez későbbiekben is sarkalatos pontnak mutatkozott, hisz a pszichoszexuális és anyagi függetlenség egymáshoz képest relatív távolodása a posztadoleszcencs szerkezet feltételének mondható (Máder, 2007).

Mindezeket a szakirodalom különbözőképpen értelmezi. Például Olk a homogén életszakasz megszűnéseként interpretálja (Olk 1984), mások pedig egyre inkább távolodó határvonalat látnak a fiatalkor és a felnőttkor között, megint mások a fiatalkor kitolódásának tekintik (Vaskovics, 2000). Ez utóbbi állásponttal azonosulok, hozzátéve, hogy a felnőttkor bizonyos dimenziói pedig korban korábbra tolódtak.

Magát a koncepciót Keniston vezette be a tudományos diskurzusba. Szerinte a modern társadalmakban a szexuális érettség és a szociális felnőtté válás, illetve a felnőtté válás dimenziói (Vaskovics alapján: jogi, lakhatási, anyagi, önálló döntést hozó és szubjektív) egymáshoz képest elcsúszva jelentkeznek. (Keniston, 1968) .

Arról, hogy valóban új életszakaszról beszélhetünk-e, megoszlanak a vélemények. Vannak, akik a „modern kor új életformájának” titulálják, például Somlai egyenesen „új ifjúságról” beszél (Somlai, 2007). Nem áll módomban társadalomtörténeti áttekintést nyújtani, ám elfogadásra javaslom azt a megállapítást, hogy - habár hasonló példa volt a történelemben és ez a szakasz nem feltétlenül a modern kor prototípusa - a társadalmi modernizáció nagymértékben hozzájárult a posztadoleszcencia sajátosságainak felismeréséhez, a fogalom kiszélesítéséhez és legfőképpen intézményesedéséhez. (Vaskovics, 2000).

Ha újnak nem is, egy társadalmilag meghatározott önálló periódusnak mindenféleképpen tekinthető. Abban az esetben nevezhetjük egyedinek, ha önálló stílusjegyeket hordoz, tehát jellemzői nem feleltethetőek meg egyértelműen sem a kamasz, sem a felnőtt szakasz sajátosságainak, hanem a posztadoleszcens állapot szignifikánsan megkülönböztető tulajdonságokkal bír. Ezek az ambivalens körülményekből eredeztethetőek. (Például a szülői háztól való függőség - önálló fogyasztási szokások...stb.)

Zinnecker szerint a posztadoleszcensek morálisan, intellektuálisan, politikailag és szexuálisan autonómok, ellenben anyagi értelemben nem azok. (Zinnecker, 1982) Magam is ez utóbbi kategóriában látom ennek az életszakasznak a legjelentősebb problémáját, így vizsgálatom középpontjába helyezem a későbbiekben. 
A posztadoleszcensek így a pszichológiai feltételek alapján felnőttnek tekinthetők, viszont nem integrálódtak a társadalom intézményes szerkezetébe, tehát a szociológia kritériumait nem elégítik ki.

\subsection{A felnőtté válás definíciói és szakaszai}

A pszichológia felnőttnek tekinti mindazokat, akikben kifejlődtek az intellektuális és morális készségek, kialakult az egyéni felelősségtudat, és stabilizálódott az érték- és normarendszer. Egy szóval összefoglalva önrendelkezésre képesek. (Hurrelmann, 1994)

A szociológia felnőtt definícióját Schäfers alapján úgy írhatjuk le, hogy a felnőtteknek fenntartott társadalmi pozíciókban önálló döntési joggal rendelkeznek. (Schäfers, 1989). Fontos itt megállni egy pillanatra, és megfigyelni, hogy egy csoporthoz való tartozás annyit jelent, mint a csoport tagjai által meghatározott követeléseknek megfelelni. A későbbiekben is ebből a visszatekintő szemszögből kell látnunk a különféle dimenziókat, viszont ez a szemlélet néhány aspektusból hibásnak mondható. Hiszen az idő előrehaladásával nem csak a társadalmi feltételek változnak, hanem a generációs különbségek az értékrendszerek szintjén is manifesztálódnak. Ezzel a problémával fogunk találkozni, amikor a családalapítás dimenziójáról a későbbiekben kimondjuk, hogy nem tekinthető a felnőtté válás feltételének.

Hurrelmann is úgy fogalmaz, hogy a felnőtté válás akkor lezárt, ha az egyének a következő területeken elérik az önállóság felnőttek részéről megkövetelt fokát: foglalkozás és munka, partnerkapcsolat és család, kultúra és politika. (Hurrelmann, 1994) Ezek a kategóriák lefedik Vaskovics általam vizsgált dimenzióit.

Ezek alapján fiatal felnőttnek tekinthető, aki 18-29 éves, és túl van az összes dimenzión. ${ }^{2}$ A „twens" kifejezés azért nem állja meg a helyét, mert az pusztán korosztályi határok közé helyezné a meghatározást. Viszont sem a felnőttség, sem a posztadoleszcencia nem korosztályi, hanem jellegzetesen szociokulturális jelenség. (Vaskovics, 2000)

Ez alapján szükség van a nem önálló fiatal felnőtt definíciójára is. Ők azok, akik csak részlegesen estek túl a leválás dimenzióin. Öket a társadalomszerkezettől függő korlátozások gátolják abban, hogy a felnőtt szerep társadalmi elvárásainak megfeleljenek. (Vaskovics, 2000). A posztadoleszcencia pedig az a folyamat, ahogyan eljutunk a korlátozások nélküli felnőttségig.

\subsection{A szülői háztól való leválás időbeli (módbeli) dimenziói}

Vaskovics megkülönbözteti a szülői háztól való leválás időbeli („módbeli”) dimenzióit is:

- Időben késleltetett

- Részleges

- Fokozatos

- Reverzibilis

Időben késleltetett leválás alatt azt értjük, hogy az új generáció később válik felnőtté, mint ahogy azt a megelőző generáció tette. A részleges leválás azt jelenti, hogy az elszaka-

${ }^{2}$ Későbbiekben szólok róla, hogy ez csak egy iránymutató absztrakció véleményem szerint. 
dás dimenziói egymáshoz képest aszinkronban jelentkeznek. Vannak dimenziók, amelyek korábbra csúszhatnak (pl.: az önálló döntést eredményezőn belül a szexualitás), és vannak, amelyek később jelentkeznek (pl.: anyagi függetlenség). A fokozatos leválást említve arról beszélünk, hogy a dimenziókon belül is találhatók további lépcsőfokok. Például az anyagi önállóságot sem feltétlenül egy csapásra éri el az ember, hanem kezdhet alkalmi munkákkal, majd részmunkaidőben dolgozik, és csak a végén kerül főállásba, amelyből végül képes lesz eltartani önmagát. Az utolsó időbeli dimenzió a reverzibilitás. Roppant lényeges elemnek tartom, ugyanis a reverzibilitás jellemző a „visszaeső” egyetemistákra, nevezhetjük őket ,jo-jo generációnak” is. Habár később bőven lesz róla szó, itt mégis ki kell térni a posztadoleszcencia okaira, amelyek közül a legfontosabb az felsőoktatás expanziója. Ehhez szorosan kötődik a Miller és Roby (1974) féle „papírkórság” és Bourdieu intézményes kulturális tőke fogalma. (Bourdieu, 1998 /1983/). Számos válaszadóm jelölt meg az egyéb végzettség kérdésénél OKJ-s okleveleket, másoddiplomákat, PHD diplomákat, tanfolyamokat, számtalan nyelvvizsgát és egyéb felhalmozott igazolást, amely a kulturális tőkéjüket bizonyítja. Ellenben ez egyrészről zsákutca is, hiszen nem lehet valaki egyszerre pályakezdő és munkatapasztalattal rendelkező, habár a foglalkoztatók megkövetelik (Balla-Mokos, 2007, 23.o.). Ezáltal még későbbre csúszik az anyagi függetlenség dimenziója, még akkor is, ha fokozatosan elindul a tanulmányok alatt a munkatapasztalat szerzése. Természetesen, ez csak egy aspektusa annak a kérdésnek, hogy miért is ülnek vissza az iskolapadba akár a harminc évesek is. Magyarországon ez nem egyszerủen szórakozásból adódó „gap year "3. Sok hallgatóban ott a bizonytalanság az életpályájukat tekintve, ezért váltanak időközben tanulmányaikban. Ez a folyamat is összetett társadalmi és pszichológiai háttérrel rendelkezik, viszont most magyarázatként csak Elkind „hurried child" (2001, /1969/) koncepcióját emelném ki: egyszerre felgyorsult és lelassul az idő az oktatás szempontjából. Ugyanis már az egészen kicsi gyermekre is a szülőkön át nyomást gyakorol a társadalom a pályaválasztás tekintetében (már az általános iskolai tagozatok vagy a középiskolák, fakultások kiválasztásával), aki a felsőoktatásba jutván pedig belekerül a bizonytalanságból adódó reverzibilitásba. Azonban nem csak az oktatással kapcsolatos reverzibilitás létezik. A szülői háztól való leválás folyamatában visszalépés történhet akár egy szakítás után is, minek következtében az egyén visszaköltözik a szüleihez, vagy az állása elvesztése miatt újra a szülei anyagi segítségére lesz utalva.

\section{A kortárs egyetemisták és a szülői háztól való leválás dimenzió}

Most, hogy áttekintettük a posztadoleszcencia fogalmát, lebonthatjuk a kérdőives kutatás eredményeit Vaskovics László dimenzióira, aki megkülönböztet objektív leválási formákat:

- Jogi értelemben vett leválás

- Közös fedél alól történő leválás

- Anyagi - pénzügyi leválás

- Önálló döntést eredményező leválás

És szubjektív leválási formát: 
- Öntudatosulás

A jogi értelemben vett leválás a nagykorúság kezdete. Ettől a dimenziótól kezdve számolunk posztadoleszcenciával. Számomra itt ellentmondás található, hisz gyakran megesik az is, hogy esetleg egy másik dimenzió következik be előbb. Hiszen a témára eleinte fejüket felkapó kutatók is a szexualitás korai próbálkozásaira figyeltek fel a fiatalok körében, amelyet én az önálló döntés kategóriájába soroltam. Valószínủleg az oka annak, hogy mégis kiemeltük origóként ezt a dimenziót az, hogy a nagykorúság az egyetlen objektíven és általános mérhető közülük. A többi kategória vizsgálatát nagyban befolyásolja a vizsgált csoport individuális heterogenitása, hiszen a posztadoleszcensekről halmozottan elmondható, hogy nem egységesek, ezért torzít minden esetben a minta. Továbbá az eredményeket befolyásolják a korosztály szélsőségességéből adódó különbségek is, de erre igyekszem kitérni ott, ahol komoly átalakító tényezőt jelent, és hangsúlyozni, hogy a korosztályi megkülönböztetés csak érdekesség, mert a posztadoleszcencia nem korfüggő, hanem a társadalomszerkezet által meghatározott feltételek be nem következéséből adódik. ${ }^{4}$

\subsection{Közös fedél alól történő leválás}

A két szorosan összetartozó és meghatározó dimenzióval kezdjük, azon belül is a közös

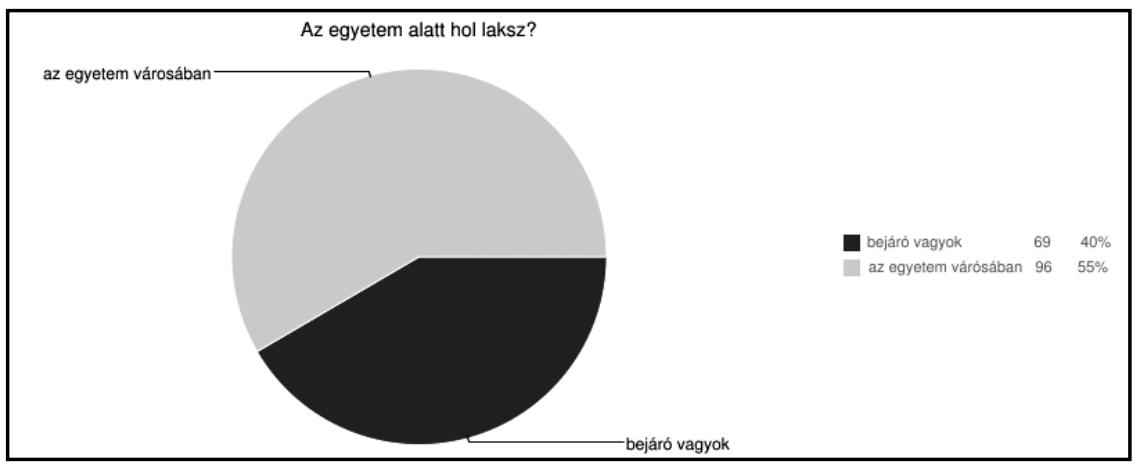

Az egyetem székhelye különbōző-e az állandó lakhelyedtöl?

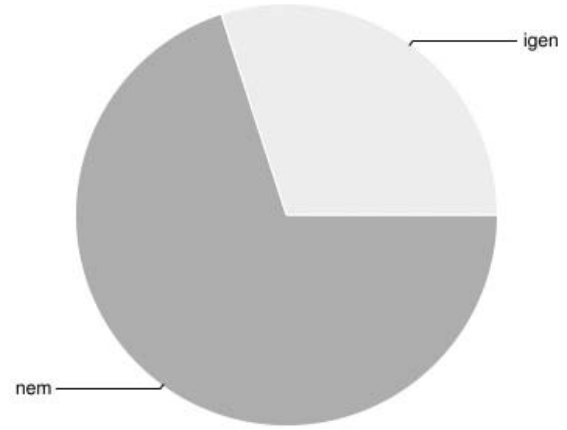

${ }^{4}$ Megjegyzendő, hogy az Ifjúság 2004 is ekkora amplitúdóval operált a korosztályt tekintve. 
fedél alól történő leválással. A válaszadók 51\%-a mondta, hogy a szüleivel él (további 5\% rokonnál), ami korreláltatva azt eredményezte, hogy a vizsgált harmincasok (kb. 17\%) körül-belül 10\%-a nem költözött el otthonról, és nagyjából 20\%-ának nincs saját vagy részben saját tulajdonú lakása. A teljes vizsgált csoport egyharmada viszont rendelkezik saját vagy részben saját lakással, főként a kései huszonévesek. A maradék megoszlik a kollégium, az ismerős, az élettárs és az albérlet között. Azzal is számolni kell, hogy háromnegyedük az egyetem városában lakik, és egyharmaduk ingázik. Ez befolyásolja a szülőktől való különköltözést is.

Azt a 33\%- ot, akik saját tulajdonnal bírnak, egyharmad részben a szülei is segítették lakásához jutni. Továbbá azt is érdemes megemlíteni, hogy egy esetleges családalapításhoz

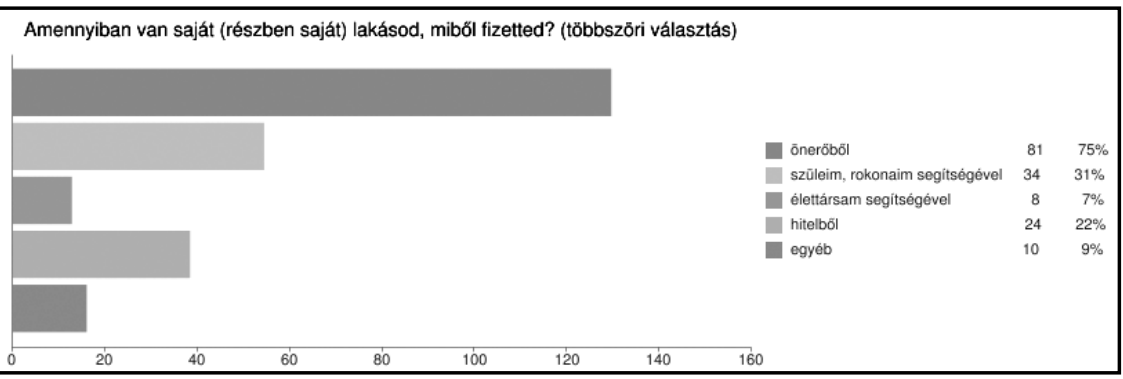

nem mindegy a lakás mérete sem, de erre vonatkozóan nincs adatunk.

Mindegyik dimenziónál igyekeztem szubjektív szempontokat is vizsgálni, arra vonatkozóan, hogy mennyire érzik a helyzetüket problémásnak a válaszadók. Nagyjából egyharmaduk úgy érzi, a lehetőség hiányában nem költözik el otthonról.

\subsection{Anyagi - pénzügyi leválás}

Kiemelkedően fontos kategóriáról van szó, hisz Gillis is úgy határozta meg a posztadoleszcenciát, mint „gazdasági alapok nélküli nagykorúság”. (Gillis, 1982, hivatkozva Máder, 2007) Ezt a dimenziót a vizsgálatomban eltorzítják a harmincasok, ugyanis összefoglalásként az látható, hogy a megkérdezettek fele foállásban dolgozva (általában szakmájában) el tudja tartani önmagát. Mégis mögé kell jobban nézni az adatoknak. Már összevetve

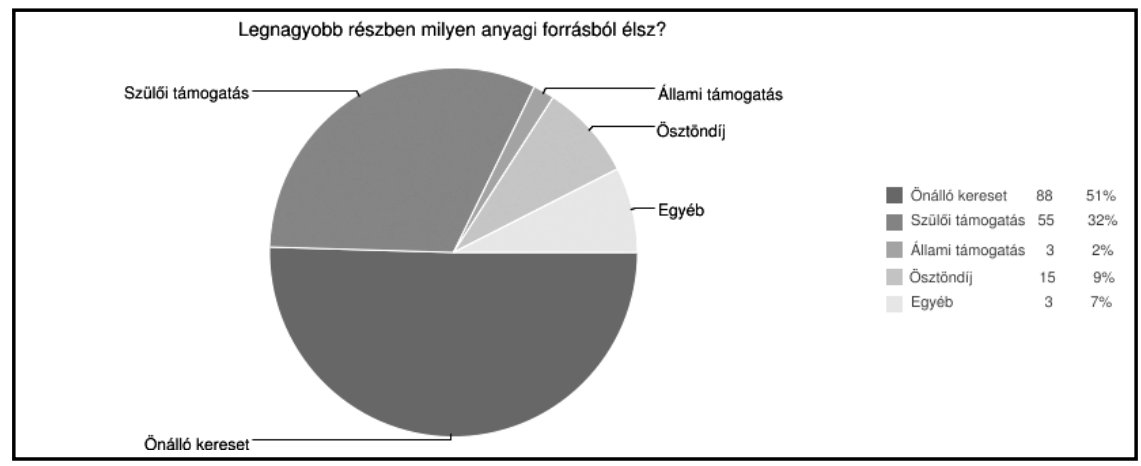


a lakhatás dimenziójával is ellentmondást találunk. Ha csak egyharmaduk vezet önálló háztartást, akkor a fele nem állíthatja, hogy önmagát képes eltartani, hiszen az önálló élet (háztartásvezetés) viszi el leggyakrabban a fizetés legnagyobb részét. Ezt a szempontot a válaszolók egy része figyelmen kívül hagyta.

A válaszadók $15 \%$ - a teljesen eltartott, nem dolgozik. $28 \%$ pedig alkalmi munkát végez, amiről belátható, hogy nem az öneltartás legbiztosabb módja. Ez kiad nagyjából 45\%- ot, amely képtelen eltartani önmagát. Másik 46\% foállásban dolgozik, a maradék pedig részmunkaidőben. Érdekes megjegyezni, hogy fele-fele arányban dolgoznak a szakmájukban és nem szakmájukban. A foállás ennek egy jelentős részét elviszi. Viszont a nem szakmájukban dolgozó majdnem 50\% számára ez is megterhelő lehet.

Fontos kiemelni, hogy $32 \%$ főként a szülei keresetből él, és saját bevallása szerint $45 \%$ nem tudna a szülei támogatása nélkül megélni. A szubjektív szempontokat vizsgáló ellenőrző kérdéseim is azt igazolták, hogy a válaszadók körülbelül egynegyede érezte magát nehéz anyagi helyzetben, és kb. 35\%-ukat aggasztja, hogy nem függetlenek anyagilag.

\subsection{Az önálló döntést eredményező leválás}

Ezt a dimenziót én további három alegységre osztottam:

- Szexualitás - párkapcsolat - család

- Politika és társadalom

- Egyéb szubjektív döntéshozatal

a) Szexualitás - párkapcsolat - család

Korábban már utaltam rá, hogy a családalapítás mint önálló dimenzió elvesztette jelentőségét a felnőtté válás lépcsőit tekintve, azáltal, hogy megváltozott a családmodell (Tóth, 2007). Viszont vannak komponensei, amelyek még mindig szoros összefüggésben állnak a felnőtté válással (felelősségvállalás, önálló döntés, választás), így betagoltam őket az önálló döntés kategóriája alá.

A nyílt kérdésekből látszik, hogy sokan nem terveznek családot alapítani, vagy csak hosszabb idő múlva. Továbbá nagy részük nem vallja, hogy lehetőség hiányában nem alapít családot. ${ }^{5}$ Elmondható tehát, hogy a felnőtté válás jele, ha megtörtént a családalapítás, de annak hiánya, nem egyértelműen befolyásoló tényező. Ám ez csak azokra vonatkozik, akik elvi meggyőződésből nem ugranak fejest a házasságba vagy gyermekvállalásba. Tapasztalati úton tudhatjuk, hogy számos olyan ember él nem csak a huszonévesek, hanem a náluk idősebbek közt is, akik felelősségtől való menekülés, összeférhetetlenség vagy egyéb individuális ok miatt nem állapodnak meg. Így megint fontos hangsúlyozni, hogy a dimenziók csak iránymutatásra szolgálnak, hogy valamiképpen mérhetővé tegyék azt, amit nagyban befolyásolnak az egyéni tényezők. Például léteznek családanyák, akik hadseregnyi embert irányítanak, ellenben esetleg nincs önálló keresetük vagy hidegen hagyja őket a politika - ettől még nem tekintjük őket posztadoleszcensnek. Viszont egyedülálló, szüleivel élő harmincas férfiak biztos egzisztenciával is ebbe a kategóriába eshetnek. Ez alapján elmondható, hogy a „felnőtt” a hurrelmanni értelemben absztrakt fogalom - rit-

${ }^{5}$ Ellenben a gyerekvállalási kedv nem csak elvi, de gazdasági okok miatt is csökken a rendszerváltás óta. 
kán teljesíthető az összes dimenzió. Mégis viszonyításként kell felhasználni, és számolni kell a posztadoleszcens állapottal az egyértelmű esetekre való tekintettel, és a kivételeket háttérbe kell szorítani, hogy elindulhasson a megoldáskeresés.

Ahogy korábban láttuk, a tudósok a szexuális és az egyéb függetlenség ollójának szétválására figyeltek fel elsőként. Mindemellett önálló döntés és felelősségvállalás szempontjából is jelentős mérföldkő. Ezért találtam kiemelkedően fontosnak vizsgálni a szüzesség elvesztésének kategóriáját. Átlagban és gyakoriságban az eredményeim mondhatni konzervatívnak bizonyultak: a szüzesség elvesztésének ideje egybeesett a nagykorúság elérésével. Ellenben a mintát széthúzták a szélsőségek: a legfiatalabb 14 éves, a legidősebb 27 éves volt. A válaszadók 9\%-a szüz - így elmondható, hogy kb. 90\% túllépet a felnőtté válás ezen feltételén, ezzel ez lett a legteljesebben teljesített (al)dimenzió. Természetesen a korai szexualitás éppen annyira lehet az éretlenség, mint az érettség jele, ezért tartottam lényegesnek a felelősségteljességgel együtt vizsgálni. Mivel nem beavatkozás mentes vizsgálatról van szó, és ez egy kifejezetten kényes téma, megeshet, hogy a válaszok nem fedik a valóságot, de kb. $80 \%$ egyetért abban, hogy nem túl korán vesztette el a szüzességét, lelkileg érettnek találta magát rá, a megfelelő partnerrel történt, és védekezik, amennyiben nem akar gyereket. ${ }^{6}$

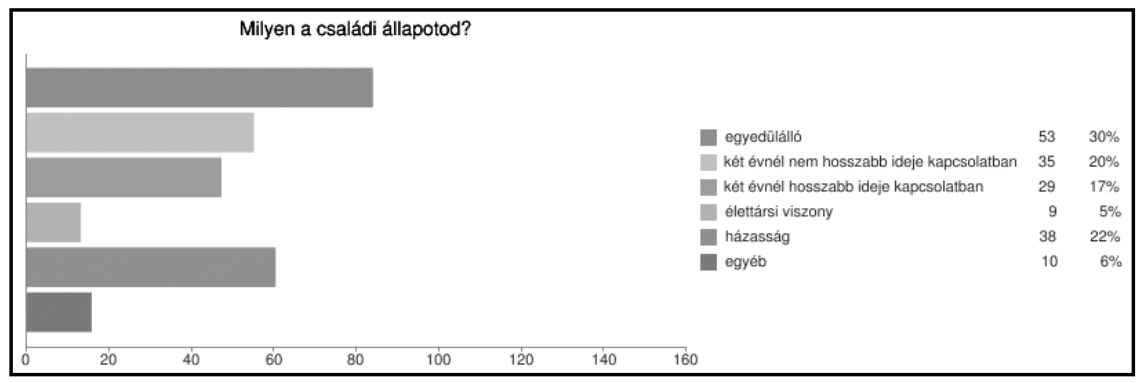

A grafikonról leolvasható, hogy nagyjából egy negyedük együtt él valakivel, és kb. $50 \%$ (átmenetileg) megállapodottnak tekinthető. Mégis jelentős adat, hogy egyharmaduk egyedülállónak tartja magát.

\section{b) Politika és társadalom}

A párkapcsolat egy szűkebb felelősségvállalás, a politikai pedig széleskörű, társadalmi felelösség, és szintén az önálló választás kategóriája alá esik. Habár sokan hangoztatják az ifjúság politikai passzivitását, például Somlai tanulmányában azt állítja, hogy az „új ifúság” elvesztette politikai lelkesedését, és már szó sincs a 60-as évek nagy generációjáról (Somlai, 2007), én az apátia ellenkezőjét tapasztaltam. Ennek oka feltehetőleg, hogy a leendő értelmiséget vizsgáltam, és az egyetemisták aktivitása nem tekinthető túl meglepőnek. Mégis, az országos arányoknál sokkal jobb százalékok jöttek ki a 2010-es választásokkal kapcsolatban:

${ }^{6}$ Van olyan válaszadó, aki már szülő, de mindegyik huszonöt évesnél idősebb. 

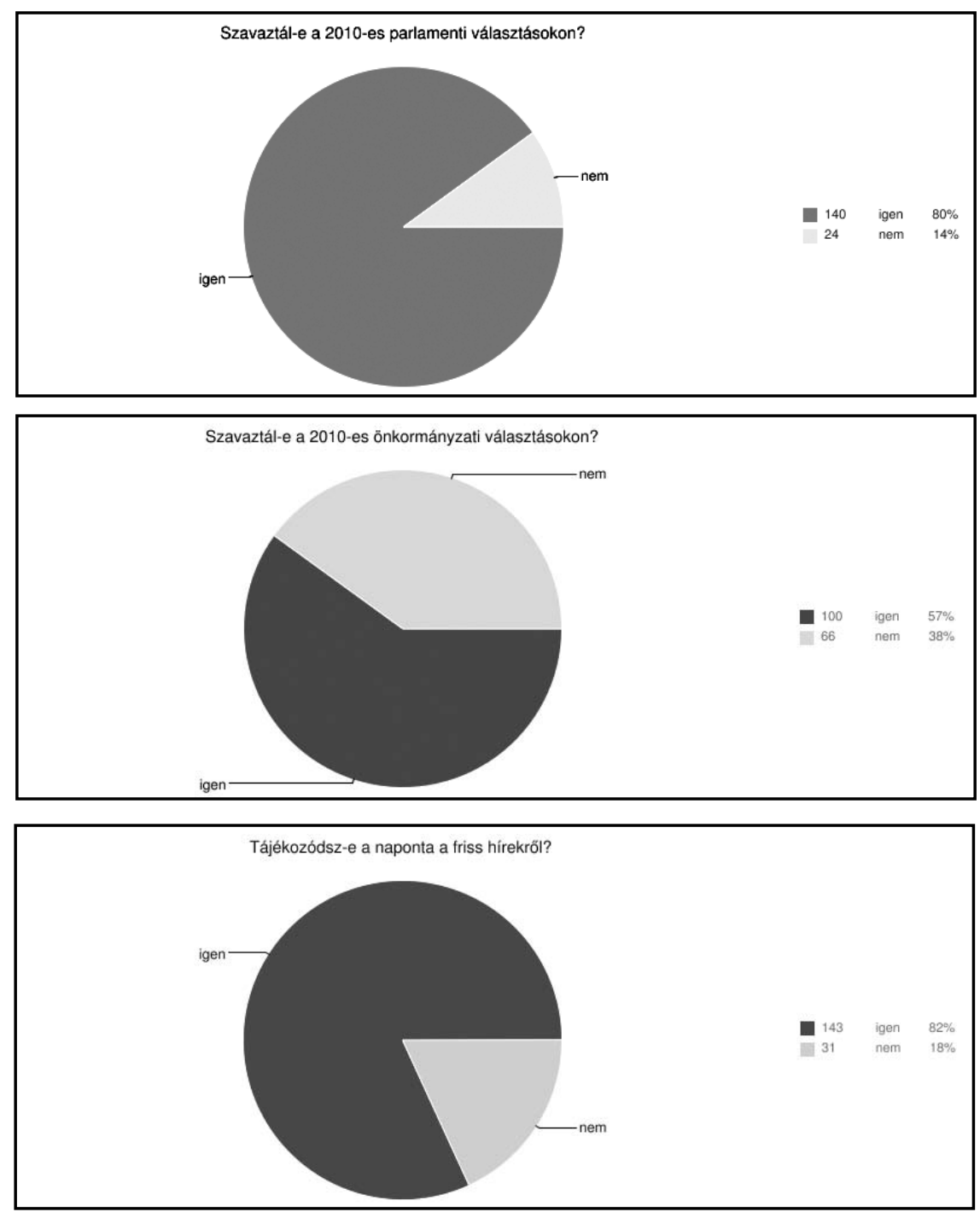

Azon felül, hogy a hallgatók 80\%-a szavazott az országgyülési, és 57\%-a az önkormányzati választásokon, egyharmaduknak határozott a politikai véleménye, és $80 \%$-a rendszeres szavazónak vallja magát.

Vizsgáltam továbbá a tájékozottságot is. A válaszadók $82 \%$-a naponta tájékozódik a friss hírekről (fóként internet), és nagyjából a felük rendszeresen olvas folyóiratot.

\section{c) Egyéb szubjektív döntéshozatal}

Ennek az aldimenziónak az empirikus vizsgálata nem hozott sikert. Próbáltam felelősségvállalást vizsgálni, de véleményem szerint a válaszok nem reprezentatívak. Ami érdekességként kiemelhető, hogy azok közül, akiknek van határozott politikai véleménye, 50\% 
nem a szülei szimpátiáját követi, és a vallásosok 15\%-a hátat fordított szülei vallásának. Mindkettő - főként a vallásválasztás - fontos lépése az önállósodásnak.

\section{4. Öntudatosulás}

Ez a dimenzió fóként azzal foglalkozik, ahogyan megszületik az egyénben a felnőttség érzete, továbbá itt vizsgáltam azt is, hogy a hallgatók, hogyan ítélik meg a helyzetüket.

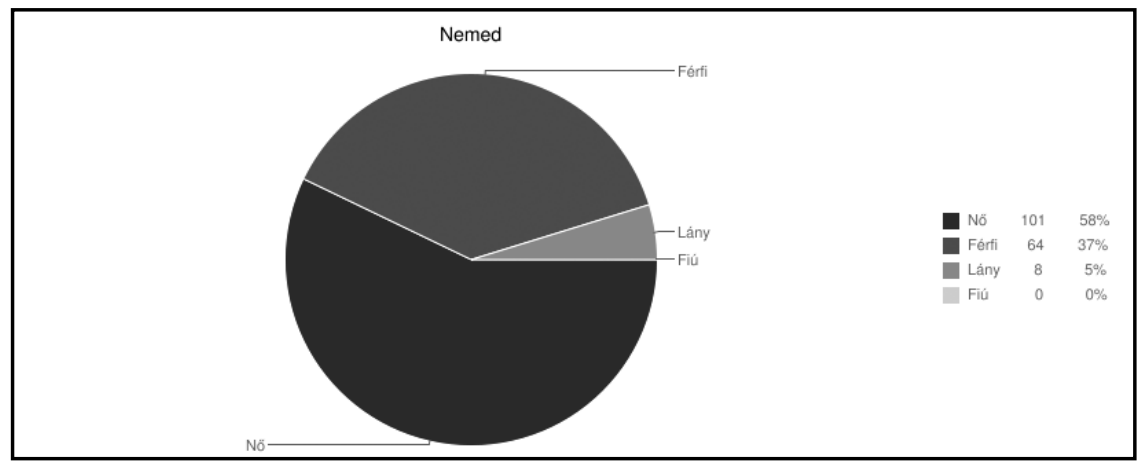

Volt egy csapdám, ami nem tekinthető hitelesnek, viszont érdekességképpen mégis beemelem. A kérdőív nyitó kérdéseinél a nemre vonatkozóan nem két, hanem négy válaszlehetőséget adtam meg. Mégis a nők 5\%-a „lányként” aposztrofálta magát, a férfiak közül viszont senki sem vallotta magát „fiúnak”. Ennél természetesen komolyabb az öntudatosulás kérdése:

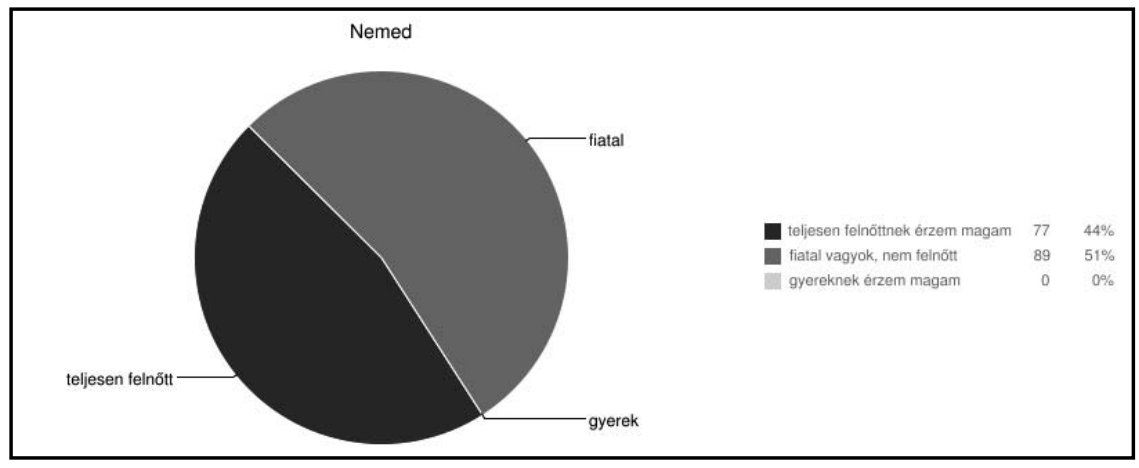

A grafikonról leolvasható, hogy a válaszadók közül senki sem érezte magát „gyereknek”, és viszonylag egyensúlyban van a „felnőttek” és a „fiatalok” aránya. Viszont mivel mi a felnőtté válás folyamatát vizsgáljuk, úgy kell értelmeznünk, hogy a vizsgált hallgatók 50\%-a nem érte el az öntudatosulás dimenzióját.

Azt is vizsgáltam, hogy mennyire elégedettek ezzel az állapottal a válaszadók, a célom ezzel az volt, hogy megdöntsem „a felelőtlen és hedonista egyetemista” sztereotípiáját. Sikerült, hisz nagyobb részt, 70\%-ban zavarja őket, hogy nem teljesen függetlenek. Ter- 
mészetesen - ahogy korábban említettem - sajátos életmóddal jár a kitolódott fiatalkor, és nem kell számon kérni rajta a felnőtt világ értékrendjét. Tehát az az egyharmad, aki élvezi, hogy nem teljesen független, nem feltétlenül a felelőtlenség szobraként kezelendő. Egy másik egyharmad pedig kifejezetten aggódik amiatt, hogy nem tud önálló életet kezdeni.

\subsection{Az eredmények összefoglalása}

Vaskovics felnőtté válási dimenzióit alapul véve és kiegészítve elmondható, hogy lakhatási értelemben a válaszadók $33 \%$-a, anyagi értelemben $\mathrm{kb}$. 50\%-a vált le a szüleiről, szexuálisan kb. 90\%-a érett, 50\%-uk állapodott meg, 76\%-uk politikailag döntéshozó és 44\%-uk öntudatosult.

\section{A posztadoleszcencia okai és következményei}

Immár képet alkothatunk az egyetemisták és a posztadoleszcens állapot kapcsolatáról, és érdemes kitekinteni az ez által felvetett problémákra és a lehetséges okokra.

Habár Kabai Imre erről szóló tanulmányában több okot is megemlít (kulturizmus, hedonizmus, alternatív életmódok, polgári iffúság mítosza...stb.) (Kabai, 2007), mégis az iskoláztatási idő elhúzódását emelem ki ismét mint legfontosabb forrást. Visszautalnék a reverzibilitás kapcsán hosszan kifejtett gondolatra a korosztályi bizonytalanságról, papírkórságról, és egy ezzel járó sajátos konkurenciaharcról (Bourdieu, 2007).

Ennek jelentős hatása van a munkavállalásra. Itt ekvivalens okozatiság figyelhető meg, hisz van, aki a munkaerőpiacon használhatatlan diplomája miatt jelentkezik újra tanulni, és van, aki a tanulás miatt nem helyezkedik még el. Mindez összefügg a jogok és kötelességek kései vállalásával (pl.: adó), és a szülőkre rótt extra terhekkel. Úgy gondolom, a szülők felelőssége is tetten érhető, hisz elvárásaik átalakultak. Nyugodt szívvel engedik vissza az iskolapadba a gyereküket egy jobb állás, magasabb pozíció vagy fizetés megszerzése érdekében.

Másrészről valószínűleg a gyereknevelés szempontjából is hasznosabb lehet a szülőkkel együtt élni, de nem kell ilyen messzire szaladni, hisz egész egyszerűen gazdaságosabb hazaköltözni vagy otthon maradni a teljes családnak, mint egy külön élő gyereket támogatni (pl. vidéki egyetemisták támogatása). Mindezek megadhatják a posztadoleszcnes állapot legitimációját a szülők szemében.

Konfliktus figyelhető meg a szabadidő-felhasználási és fogyasztási szférában is. A fiatalok képezik a célcsoportot, habár a fizető képességük korlátozott. Ez továbbá a mintaadás és a mintakövetés feszültségével is jár. A szülőt mint példaképet nem lehet kiiktatni, de számos más, a fogyasztási szférából közvetített mintát és identitást lehet találni, miközben maga a fiatal is mintává válik a szülei számára. „Az ő választásaikat akarják követni mások, miközben maguk is bizonytalanok" (Somlai, 2007, 43.o.) Mindez a bizonytalanság és ellentmondás, a szabadság és bezártság, az autonómia és a függés összeütközése az egyénen belül szerepkonfliktushoz vezethet.

\section{A kutatás további perspektívái}

A vizsgálat csak a felsőoktatásban résztvevők egy csoportjára vonatkozott, és nem áll módunkban azon belül sem minden részletet megvizsgálni. Azon felül, hogy diakrón szemléleten át is érdemes lenne a változást megfigyelni, és a fiatalok más végzettségủ csoport- 
jaira is kiterjeszteni a kutatást, majd összehasonlítást tenni az egyetemistákkal, a meglévő kutatásban is vannak további lehetőségek. Meg lehetne nézni, hogy a különféle képzési területek diákjai hol tartanak egymáshoz képest a leválás lépcsőiben, illetve az öntudatosulásban, milyennek látják az életperspektíváikat. Megérné vizsgálni a családi háttér és felnőtté válás összefüggését, a testvérek számát és szociális helyzetet tekintve. Hiszen nem csak kitolódhatnak, hanem korábbra is csúszhatnak a felnőtté válás dimenziói, például, ha hirtelen változás miatt gondoskodni kell a testvérekről vagy a szülőkről. Lehetne vizsgálni a nemek és a leválás lépcsőinek összefüggését, főként a családalapítás szemszögéből. Például, a nők gyermekvállalási szándékait egybevetni a tanulmányi szándékaikkal, hiszen a szülés még jobban elnyújtja a képzési időt. Korábbi vizsgálatok egyébként azt mutatják, hogy a nők hamarabb beteljesítik a dimenziókat - feltehetően ilyen okokból. ${ }^{7}$ Valószínüleg további távlatok is nyílnak az ehhez hasonló vizsgálatok során.

\section{Konklúzió}

Végeredményként elmondható, hogy a mintát alkotó felsőoktatásban résztvevő válaszadók morálisan és intellektuálisan autonómok, és egy meglehetősen nagy részüknek nem kell aggódnia az anyagi függetlenség miatt sem. De az összesített eredmények szerint egy negyed részük viszont valóban elveszettnek érzi magát. Ez nem csak a fiatalok felelőssége, és nem pusztán az ő felelőtlenségükből származik, hanem a körülmények determinálják a posztadoleszcens életszakasz elnyúlását vagy éppen rövidülését. Innentől a társadalom feladata, hogy eldöntse, valóban jelent-e problémát a kitolódott fiatalkor, és szükséges-e az általa felvetett kérdésekre megoldást találni?

\section{Irodalomjegyzék}

Balla Viktória - Mokos Béla 2007. Ifjúsági munka és mobilitás. Új ifúsági szemle - ifjúságelméleti folyóirat. 2007, nyár, 23-32.

Bauer Béla - Szabó Andrea. (szerk.) Ifjúság 2004. Gyorsjelentés. Mobilitás Ifjúságkutató Iroda. Budapest.

Bourdieu, Pierre 1997 (1983). Gazdasági töke, kulturális töke, társadalmi töke. In: Angelusz R. (szerk.): A társadalmi rétegzödés komponensei. Új Mandátum Kiadó, Budapest.

Bourdieu, Pierre 2008. A társadalmi egyenlötlenségek újratermelödése. General Press.

Elkind, David 2007 (1969). The Hurried Child: Growing Up Too Fast Too Soon (Third Edition). 25th Anniversary Edition. Cambridge, Da Capo Lifelong Books.

Hurrelmann, Klaus 1994. Lebensphase Jugend: Eine Einführung in die sozialwissenschaftliche Jugendforschung. Weinheim/ München: Juventa

Kabai Imre 2007. A magyar egyetemisták és fơiskolások életútja, élettervei 2004-ben In: Somlai Péter (szerk. ): Új ifuúság - Szociológiai tanulmányok a posztadoleszcensekről. Napvilág Kiadó.

Keniston, Kenneth 1968. Young Radicals. New York: Harcourt, Brace \& World.

Máder Miklós Péter 2007. A szülöktöl való elszakadási dimenziók

mentén létrejött alcsoportok. Új ifjúsági szemle - ifjúságelméleti folyóirat 2007 tavasz, 125-130.

Miller, S. M.-P. Roby (1974). A papirkórság csapdája. In: Ferge Zs.-Háber J. (vál.): Az iskola szociológiai problémái. Közgazdasági és Jogi Könyvkiadó, Budapest.

Olk, Thomas 1984. Jugend und gesellschaftliche Differenzierung. Zur Entstrukturierung der Jugendphase. In: Zeitschrift für Pädagogik. Beiheft.

Schäfers, Bernhard 1989. Soziologie des Jugendalters. Opladen: Leske + Budrich.

Solai Péter 2007. A posztadoleszcensek kora. Bevezetés In: Somlai Péter (szerk.): Új ifjúság - Szociológiai tanulmányok a posztadoleszcensekről. Napvilág Kiadó.

Tóth Olga 2007. Fiatalok párkapcsolatai történelmi háttérrel. In: Somlai Péter (szerk.): Új ifuúság - Szociológiai tanulmányok a posztadoleszcensekről. Napvilág Kiadó

Vaskovics László 2000: A posztadoleszcencia szociológiai elmélete. Szociológiai Szemle, 20(4): 3-.20.

Zinnecker, Jürgen 1982. Porträt einer Generation. In: Jugend '81. Lebensentwürfe, Alltagskulturen, Zukunftsbilder. Jugendwerk der Deutschen Shell 80-122. Leske + Budrich

${ }^{7}$ Továbbá a nők általában felülreprezentáltak az ilyen vizsgálatokban, és befolyásoló tényező még, hogy általánosságban több nő tanul felsőoktatásban, mint férfi. 
Korenyák Zsófia - Pataki Teréz:

\section{Élménykeresők}

A nyolcvanas évek generációjának élmény-megélési stratégiái

\section{Mit és miért}

A Kontra Mủhely Alapítvány felhívásában arra bíztatott minket, hogy járjunk körül - „nem tudományosan, de megalapozottan” - egy témát, és azt valamiképpen a nyolcvanas évek generációjával hozzuk viszonyba. Éltünk a lehetőséggel, és témául az „élmény” fogalmát választottuk.

Egyik kiindulópontunk Schulze élménytársadalom-fogalma volt. ${ }^{1}$ Röviden összefoglalva, Schulze a jóléti társadalmakat a bőség, vagy az élmény társadalmának nevezi. A bőség társadalmában - szembeállítva a korábbi időkkel - a cselekvést már nem a szűkösség, és a megélhetés kényszerei korlátozzák: motivációjának alapját a jóllét, a kiteljesedés, és a teljesség megélése, valamint ennek elérési módjának szabad megválasztása képezik. Az egyének számára a túlélés helyett az élet minősége - kellő mélysége, tartalmassága, színessége és értelme -, és annak biztosítása áll az első helyen. Felértékelődik a szubjektivitás, és vele a „benso" igények, a kiteljesedés, az öröm, és mindennek szolgálatában az élmény és az élményszerzés áll. Ugyanakkor az élmények megélését nem evidensen egyszerü teljesíteni: éppen a minket környezö, az élménytársadalom lényegét adó termék-túlkínálat az, ami kétségessé teszi az élmények minőségét, mely megkérdőjelezi a választott élmény egyedi voltát, és döntéseink helyességét. Az élménytársadalomban élőnek - némi túlzással persze - szüntelenül döntést kell hoznia, állást kell foglalnia, vajon az a termék, az a szolgáltatás, az a kapcsolat éppen a legjobb választás volt-e, önnön kiteljesedése és életének teljessé tételének érdekében. A „szép élet projektjének” nehézsége, egy élmény választása szükségképpen ezernyi másikról való lemondást is jelent.

A nyolcvanas években születettek a rendszerváltás utáni első olyan generáció, mely - a korábbiakhoz képest mindenképpen - „bőségesebb”, javakban gazdagabb társadalomban nőtt fel, és legfeljebb csak szüleitől, vagy tanulmányaiból ismeri a hiánygazdaság fogalmát. Vajon hogyan vannak ők, a nyolcvanas generáció az élménnyel? Hogyan látják ők a bőséget, hogyan élik meg a választás szabadságát? Mennyiben jellemző rájuk az élménykereső, netán élményhalmozó attitűd?

A nyolcvanas években születettekről tekintélyes mennyiségű szakirodalom halmozódott fel. Nagy vonalakban elmondható, hogy a tanulási idő meghosszabbodása és a késői mun-

${ }^{1}$ Éber Márk Áron: Élménytársadalom. Gerhard Schulze koncepciójának tudás- és társadalomelméleti összefüggéseiről. Budapest: ELTE Társadalomtudományi Kar, 2007. 
kavállalás egyfelől egzisztenciális függőséget - s ezzel együtt frusztráltságot, kiszolgáltatottságot, és nemzedékek közötti konfliktust -, másfelől késői önállósodást, késői felelősségvállalást, nehézkesebb integrációt eredményez. Sok tekintetben bizonytalan élethelyzetük, és a felgyorsult élettempó felszínességet eredményez, mely nem „csak” az életmódjukra, de alapvető döntéseikre, értékválasztásaikra, kapcsolataikra is rányomja bélyegét. A fogyasztásra és az élménykeresésre inkább egyfajta halmozás, kapkodás jellemző, és ebben a nagy kapkodásban nem szívesen tartozik másokhoz: társakhoz, csoportokhoz, intézményekhez. Elutasítja a kötöttségeket, úgyis, mint a kötelezettségeket. Az erősödő individualitás további megnyilvánulása, hogy alacsonyabb a tűrőképessége másokkal - más generációkkal és más kortársakkal - szemben. ${ }^{2}$

Mindezeket az elmarasztaló megállapításokat szem elött tartva - vajon milyen élményeket keresnek ők, a „ezek a fiatalok”? Valóban felszínesek volnánk-volnának, én-központúságuk valóban csak a laza kapcsolatokat engedné meg? Valóban csak az élményszerzés motiválja őket? Mit tudnak kezdeni a bőség társadalmának túlkínálatával? Mi jelenti az élményt számukra?

\section{Módszerünk: éjszakai open air}

Kérdéseink megválaszolására szórakozóhelyek közönségét kerestük fel, méghozzá esti, illetve éjszakai időpontokban. A legtöbb interjút a Gödörben készítettük. Ez a hely nevezhető városrésznek, fogalomnak, illetve életérzésnek is - központi elhelyezkedésével, színes és változatos kulturális programkínálatával, megfizethető áraival, nagyon sok - majd' minden - ember ízlésének megfelel. Heterogén közönségének és nyitott légkörének köszönhetően mintavételi szempontból is ideális: így hát bármerre is indultunk, előbb-utóbb mi magunk is a Gödörben találtuk magunkat.

Jelen kutatásunk válaszadói húsz és harminc év közötti fiatalok voltak. Az átlagéletkort tekintve megállapítható, hogy a mintában a fiatal huszonévesek kerültek túlsúlyba, melyet pontatlan - ránézésre történő - becsléseinknek köszönhetünk. Eleinte mi magunk is félénkebben kapaszkodtunk diktafonunkba, félve a tolakodónak tűnő és a könnyed esti kikapcsolódáshoz nem túl szorosan illeszkedő kérdéssorral („Mit jelent számodra az élmény fogalma?”,Mi jelent számodra élményt?” „Mitől válik számodra valami élménnyé?"), mégis visszautasításnak - várakozásainkkal ellentétben - legcsekélyebb jelét sem tapasztaltuk. Másik aggodalmunk az volt, hogy a válaszok túlontúl hasonlítani fognak egymásra (feltételeztük például az ivás-bulizás-furcsatörténetek háromszög gyakori előfordulását), de ez a félelem is alaptalannak bizonyult. A kapott válaszokat begépeltük, majd egy táblázatban rögzítettük, és kódokkal láttuk el. Az így kialakult kategóriákat fogjuk a továbbiakban bemutatni.

\section{Másféle kategóriákról, még elébb}

Schulze mellett kutatásunk másik - módszertani - kiindulópontja, illetve támasza Csíkszentmihályi Mihály flow-elmélete volt ${ }^{3}$. Csíkszentmihályinál az örömhöz vezető út egy

${ }^{2}$ Tibori Tímea: Nem-et mondás? Igaz-mondás. In: Educatio 19. évf. 2. sz. (2010), p. 191-202.

${ }^{3}$ Csíkszentmihályi Mihály: Flow: Az áramlat. A tökéletes élmény pszichológiája. Budapest, Akadémiai Kiadó, 1997. 
olyan felfokozott és fókuszált állapoton keresztül történik meg, mely hasonlatos a pszichológiában (is) ismeretes lazító módszerrel, a relaxációval. Az elengedés, beleengedés, annak a hite, hogy létezik egy mindent meghatározó rend, melynek mi magunk is (alkotó)elemei vagyunk, $s$ tudatunkkal képesek vagyunk azt fenntartani, olyan magabiztossággal tölthet el bennünket, mely hatással lesz a külvilágra, $s$ amely szintén visszahat ránk, változások beindítója lesz. Maga az élmény állapota pedig mintha módosítaná valóság-érzékelésünket. A hangsúlyok átcsoportosulnak: egy-egy öröm-tevékenység közben önfeledten szabadnak, harmonikusnak élhetjük meg magunkat, nem ritkán spirituális egyé olvadás érzése keletkezhet. Öröm-tevékenység lehet például a zene: „,...mindenféle zenéket játszottunk, én gitárral, és én voltam a zene forrása... vittek a nóták és én csak egy közvetítő valami voltam. Átfolyt rajtam a zene... ” (27, F $)^{4}$

A flow felé vezető úton az első lépés egy - jó eséllyel - teljesíthető feladatot keresni. Ezek után fontos, hogy a feladat céljai kellőképpen világosak legyenek teljesítésükhöz. A maximális összpontosítás, az egyéb, nem a céltevékenységgel összefüggő tényezők kizárása szintén nagyon lényeges. Ez igazán jelentős eleme a flow-élmény átélésének, ugyanis ettől válik kicsit „más világgá” az adott foglalatosság. Az, hogy mihamarabb visszajelzést kapjunk, szintén elengedhetetlen abban, hogy tudjuk, hol is tartunk az elvégzendő cselekvésünkben. Szükséges egy saját cselekedetek feletti kontroll-érzés, annak megtapasztalása, hogy kezünkben tartjuk az irányítást, urai vagyunk az átélt helyzetnek. Amennyiben ez párosul egy erőlködésmentes elkötelezettség-érzéssel is, akkor ideális esetben megszűnik a léttel való foglalkozás (nem görcsölünk az én-határaink védelmének folyamatos felülvizsgálatán) és az időérzékelés is megváltozik: az idő vagy nagyon felgyorsul, vagy nagyon lelassul számunkra.

Egyfelől fontosnak tartjuk tanulmányunkba beemelni a flow alapgondolatát, mégis, szándékunk nem a szerző kategóriáinak igazolása volt. Ezek közül némelyek az interjúelemzéskor „maguktól” köszöntek vissza, mások a kutatás során felmerült kérdésekre adnak választ.

\section{Az élményközvetítők}

A beszélgetésekből kigyüjtött hetven választípust hét nagyobb kód alá rendeztük be. Ezek a kódok az én élmény-elérési útvonalait jelölik. Minőségüket tekintve hídként viselkednek: ezek révén lehet eljutni az élményhez, illetve megélni az élményt; bizonyos esetekben pedig teret biztosítanak az élmény megmutatkozására. Az ábrán igyekeztünk feltüntetni az élményközvetítők irányultságát is. Jól látszik, hogy a válaszadóink az élményt nem kizárólag kívülről, a külvilágtól várják. Talán ez lenne a kézenfekvőbb elképzelés: az élmény külső hatásként eléri (megfogja, megérinti) az ént, mely befogadja, átéli - de akkor is csupán csak „elszenvedi” - az élményt. A válaszokból kirajzolódnak azok a módok, illetve útvonalak, melyeken keresztül az élmény belülről is hozzáférhető: az egyén képes létrehozni élményeket, illetve képes önmagát megtenni élménye tárgyául.

Az élmény-elérési útvonalak felcímkézése nyilvánvalóan önkényes volt. Ezek a kategó-

${ }^{4} \mathrm{~A}$ zárójelben feltüntetett szám és betű az interjúalany életkorát és nemét hivatottak jelezni. 
riák nem válnak el élesen egymástól, gyakran vékony köztük a határvonal, és a válaszok több kód alá is besorolhatók - ugyanakkor, két kivétellel minden válasz besorolható volt valamelyik kategóriába.

\section{Kívülről érkezők}

Először azokról a közvetítőkről szólnánk, amelyek kívülről érkező impulzusok révén fejtik ki élmény-hatásukat az énre. A legtöbb választ a „Mások, közösség” címke alá tudtuk besorolni. Ez a kategória kétféle típust tartalmaz: a „találkozás a különössel” azokat a válaszokat gyüjti egybe, ahol a válaszadó számára az élményt egy másik, tőle nagyon távol álló, különös ismeretlennel való találkozás hordozza. Ez a különösben történő magunkra találás, az önmagunkra ismerés élménye. A „találkozás az ismerössel” alkategória az ismerőssel, a szeretettel való együttlétre utal: élmény átélése a család, a barátok, a társak révén. Végül külön alkategóriává avanzsáltuk a „szerelmet”: ebben egyszerre jelenik meg a különösben való feloldódás és az ismerősség élménye. A másik különössége és ismerőssége - ennek megélése révén gazdagodik az én, ez a gazdagodás maga jelenti az élményt.

\begin{tabular}{|l|c|}
\hline „A legnagyobb élmény az, amikor stoppolsz, és külföldön fel- \\
vesznek, és nagyon jót beszélgetsz egy olyan emberrel, akit nem \\
ismersz. Például (...) most Afganisztánból jött haza, és elmesélte, \\
$\begin{array}{l}\text { hogy ott mi volt, és nagyon jó élmény volt utazni egy olyan em- } \\
\text { berrel, akivel amit össég/ } \\
\text { Találkozás } \\
\text { a különössel } \\
\text { bennen mindegy, élmény volt, mert megéltem és örök életemre }\end{array}$ \\
\hline $\begin{array}{l}\text { „Akkor, amikor a kisfiammal lehetek. Az az igazi élmény. Sétál- } \\
\text { gatunk, mekibe megyünk, ez okoz nekem élményt így szívben, } \\
\text { aztán hétvégente szórakozás, hogy elterelje a figyelmemet erről.” } \\
(21, F)\end{array}$ & $\begin{array}{c}\text { Mások, közösség/ } \\
\text { Találkozás } \\
\text { a különössel }\end{array}$ \\
\hline
\end{tabular}

$\mathrm{Az}$ „extrémitás” címke alá azokat válaszokat gyüjtöttük, melyekben az élmény valamiképpen a kontrollvesztéshez volt köthető. Ezekben az esetekben a válaszadó úgy fogalmazta meg az élményt, mint lehetőséget, mely révén valamiképpen ki tud lépni az adott szituációból, ki tud lépni önmagából, el tudja „veszíteni” önmagát. Példa az ilyen helyzetekre a veszély és a kockázat megélése, a menekülés.

\begin{tabular}{|l|r|}
\hline „Ha én nem érzek adrenalint, akkor nem is igazán tetszik a dolog. & \\
Például a motorozásnál a gyorsaság, ami nagyon fontos nekem. \\
Az, hogy minél melegebb helyzetekben legyek. Az, hogy például \\
legutóbb, ugyebár nekem nincsen jogosítványom, és elkezdtek \\
rendörök kergetni, és ezáltal így hát... hogy mondjam általában \\
rendőrökkel szoktam szórakozni.” (19, F)
\end{tabular}


Sokak számára az élmény azáltal jelentkezik, hogy valami "nem hétköznapi" kizökkenti őket a megszokottból, meghökkenti, eltéríti a megszokott útjától. Ezeket a válaszokat, a „zökkenö” kategóriájába soroltuk be. Két típusú „zökkenőt” találtunk, az egyik ez az általánosabb, a hétköznapokból kizökkentő; a másik inkább egy olyan hatás (vagy talán hangulat?), mely a hétköznapi helyzet ünnepi megélését teszi lehetővé.

„Az élmény mindenképpen valami olyan, ami nem hétköznapi, valami különleges dolog, valami rossz, vagy jó, ami kizökkent abból, amit megszoktam. Például egy találkozás. Megismerni valakit, vagy bármi, ami nem a hétköznapjaim része."

„Néha sétálok és beszívom a levegőt, és néha nagyon nagyon jó az a levegő amit belélegzek, és pont úgy süt a nap és akkor ... de ezek a dolgok többszöröződnek, sokszorozódnak."

Hétköznapokból kizökkentő Hétköznapi helyzet különös megélése

A „gazdagit, befolyásol" alatt nagyon hasonlót értettünk. Az ide sorolt válaszokban az volt a közös, hogy ezekben az esetekben az ént érő külső hatás - mely lehet változatlanul „zökkenő”, vagy mondjuk egy közösségi élmény - az énre valamiképpen befolyással bír. Ez a befolyás, illetve a befolyás hozadéka, a gazdagodás, önmagunk változása okozza az élmény érzését.

\begin{tabular}{|l|c|}
\hline $\begin{array}{l}\text { „Ha érzek valamit, és attól kapok valami pluszt, akármit, akkor } \\
\text { azt élménynek nevezem.” }(19, \mathrm{~F})\end{array}$ & $\begin{array}{c}\text { Gazdagít, } \\
\text { befolyásol }\end{array}$ \\
\hline $\begin{array}{l}\text { „Valami, ami befolyásol téged, lehet ez egy pillanatnyi dolog, vagy } \\
\text { rövidebb.” }(19, \mathrm{~L})\end{array}$ & $\begin{array}{c}\text { Gazdagít, } \\
\text { befolyásol }\end{array}$ \\
\hline
\end{tabular}

Végül, a „gazdagít, befolyásol” címkének akár alkategóriája is lehetne a „visszajelzés”, de minthogy több ilyen válaszunk is lett, különvettük. A visszajelzés jelentése, jelentősége egyértelmű, a pozitív elismerés megélését nevezték itt a válaszadók élménynek.

\begin{tabular}{|l|l}
\hline „Nekem az egy nagyon nagy élmény volt, mikor ott lehettem, és & Visszajelzés
\end{tabular} kiválasztottak, és bemondták a nevemet." (22, L)

\section{Belülröl fakadók}

Az élmény belülről történő létrehozása, előhívása Schulze írásában is előkerült. Az élmény választása nem feltétlenül passzív folyamat: sokkal inkább egy kívülről érkező élménylehetőségekből és a benső igényekből létrejövő konstrukció. Sőt, gyakran a külvilág is felesleges luxus - az egyén képes önmaga megfigyelésével átélni élményt, vagyis önmagát megtenni élménye tárgyául - és ezt másoknak elmesélve közös élménnyé emelni.

Az élmény egón belüli keletkezésénél, illetve feldolgozásánál vissza kell térnünk valamelyest a flow fogalmára. A „flow” fogalmába tartozó élménytartalmak - a beleengedésre, sodródásra gondolunk - megtapasztalhatóak bármely eddig definiált kategóriánkban. 
Mégis, szükségesnek tartjuk a fogalom külön kategóriára bontását, mivel több interjúban önállóan is előkerült, bármiféle cselekménytől, tevékenységtől függetlenül megfogalmazva. Az élmény itt voltaképpen egy színtér, egy lehetőség, amiben az egyén a flow-n keresztül (illetve a flow-t átélve) elveszítheti önmagát, és feloldódhat.

\begin{tabular}{|l|c|}
\hline $\begin{array}{l}\text { „... ha beleengedem magam a dolgokba, meg hagyom hogy érje- } \\
\text { nek, akkor érnek.” (22, L) }\end{array}$ & Flow \\
\hline $\begin{array}{l}\text { „...olyan behatása a világnak, ami intenzívebben hat az érzékelé- } \\
\text { semre a mindennapokban.” (23, F) }\end{array}$ & Flow \\
\hline $\begin{array}{l}\text { „Élmény maga, amikor kicsit elfeledkezel magadról, tehát amikor } \\
\text { a pillanat befolyása (alá kerülsz).” (19, L) }\end{array}$ & Flow \\
\hline
\end{tabular}

$\mathrm{Az}$ „alkotás” is a belülről fakadó típus alá sorolható, ilyenkor ugyanis az egyén saját gondolatait, érzéseit igyekszik egy-egy cselekvés révén kifejezésre juttatni. Az alkotás folyamatában elérhető élmény lehet épp olyan fokú, mint mikor az alkotó magára az alkotás tárgyára - a produktumra - pillant. A koncepció rugalmas módosulását, a spontaneitást (nevezhetnénk játékosságnak is) a következőképp fogalmazta meg interjúalanyunk:

\begin{tabular}{|c|c|}
\hline $\begin{array}{l}\text { „...(Az élmény az,) mikor ugyanazt hozom létre, amit akartam. } \\
\text { Vagy, amikor egészen más születik, mint terveztem, és rájövök, } \\
\text { hogy sokkal jobb.” }(25, \mathrm{~F})\end{array}$ & Alkotás \\
\hline
\end{tabular}

A kívülről érkező élményközvetítők esetében már említett „Mások, közösségre” nem térnénk ki még egyszer, ez a típus tehát mind kívülről, mind belülről örömforrásként szolgálhat, $s$ megerősíti az egyén önmagáról kialakított képét. Végezetül megemlítenénk, hogy két válaszadónk bevallásuk szerint, más-más okból ugyan, de kerülik az élményeket, és arra törekednek, hogy minél kevesebb élmény érje őket. Az ábrán „tagadók” névvel illettük őket.

E hét élménymegélési útvonal a következő élménytartalmakhoz vezetett el bennünket:

1, Azonosulás - a másokkal való azonosulás, a másokban való önmagunkra találás élménye. A környezetből érkező, saját magáról információval szolgáló észlelés segít az egyénnek önmagát elhelyezni a Másikkal szemben, s így megtalálni a helyét a közösségben, csoportban, társadalomban. A közös tulajdonságok, tapasztalások tovább erősíthetik énjét, biztonságot adnak számára. Megerősítik abban, hogy gondolatai, cselekedetei relevánsak, tulajdonságai - a vonatkozási csoport (épp aktuális „Mások, közösség”) elvárásainak - megfelelőek, osztozni tud bennük másokkal, azonosulókkal, nincsen tehát egyedül.

2, Szabadság - a szabadság megélésének élménye, akár úgy, hogy elveszíti magát az én - „elveszíti a fejét”, „felszabadul” valami alól - akár úgy, hogy feloldódik benne. Ez utóbbi az a fajta módosult tudatállapotként is aposztrofálható jelenség, melyet flow néven illettünk korábban.

3, Változás - élmény az, ami megváltoztat, ami hozzáad az énhez. A jelenség megtapasz- 
talása során újszerủ ingerek érik az egyént, amitől gazdagodik, több lesz. További ismeretekkel, tapasztalatokkal bővül „palettája”. Ez kihatással lehet személyiségére, mely kapcsolatai minőségét is megváltoztathatja. Élmény lehet továbbá az is, ha a változást mi magunk hozzuk létre alkotás révén.

4, Produktum - Ez esetben az élmény valamilyen tárgyiasult (vagy visszajelzés esetében akár verbalizált) formához, kézzel fogható eredményhez köthető.

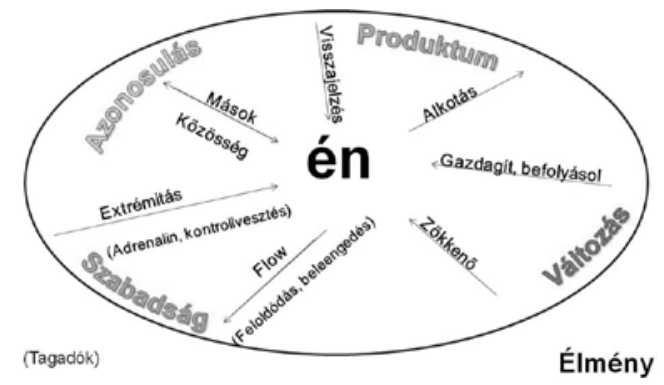

\section{Csak egy pillanatra}

Muszáj kitérnünk az Idő fogalmára. Az élményt válaszadóink majd minden esetben valamilyen idő-érzethez kötötték, ám az idő-érzet minősége már inkább megosztotta őket. Számunkra volt élmény nyomon követni azokat a dialógusokat, nemritkán vitákat, melyeket az élmény időbeliségének eltérő megélése generált. Ezekben a vitákban nemritkán nekünk is állást kellett foglalnunk, és itt derült ki, mi magunk is mennyire mást értünk élmény alatt. A válaszadók az élmény vonatkozásában az időnek két dimenzióját használták, illetve különítették el. Az egyik a megélt idő fogalma: ez alatt az élmény folyamatos, megélt minőségére utaltak, vagyis ez esetben az élmény a születéstől a halálig tart, és átfog minden pillanatot.

„Legutolsó élményem? Reggel felkeltem, sütött a nap, és jól éreztem magam. Minden olyan volt, ahogy én szeretem. Olyan dolgok vettek körül, úgy sütött a nap, olyan szögben..."

„Ha figyelünk rá, az folyton van, az élmény az az élés. (...) Bármi lehet élmény."

Idő, megélt

Idő, megélt

A másik idő-fogalom az elbeszélt idő: itt az élmény az emlékezet utólagos konstrukciójaként jön létre, és valamiképpen az időtállósághoz kapcsolódik.

„Élmény számomra az ami maradandó, tíz éves távlatból is emlékszem rá, nagyon meghatározó pillanat az életben és jó érzéssel tölt el, amire később vágysz, vagy amilyen érzést szeretnél, amit a továbbiakban is szeretnél átélni."

„Amire nem emlékszem, az nem élmény."

Idő, elbeszélt

Idő, elbeszélt 
„Ha az él-ményre gondolunk, akkor gyakorlatilag a megélt dolgokról beszélünk. Ha nagyon szigorúan vesszük, akkor az élmény, a megélt dolgok összessége. Élet. Viszont ha abból a szemszögből akarom megközelíteni, hogy mi az, amit élményként mesélek, tehát inkább egy ilyen személyesebb megközelítés, akkor azt mondanám, hogy inkább az ilyen az emlékek, amik valamiért mélyebb nyomot hagytak bennem, és valamiért ki akarom emelni őket.”
Idő, megélt ÉS elbeszélt

\section{Végezetül}

Visszatérve írásunk elején felvetett kérdésekre, a látottak-hallottak alapján kijelenthetö, hogy valóban, a megkérdezettek kimondottan keresik az élményeket: nem egy válaszadó élménygyüjtésről, halmozásról számolt be. („Ha nincs /élményed/ írjál róla naplót, s ha nincs kipipálva, akkor változtass valamin gyorsan, nem?”). Összevetettük a válaszokból kirajzolódó élménymegélési csatornákat Csíkszentmihályi kategóriáival, és három közös pontot találtunk: az alkotás és a visszajelzés örömét, illetve az idő-érzékelés megváltozását, vagyis az élménynek az idő szubjektív megélésére tett hatását. Érdekes különbség ugyanakkor, hogy Csíkszentmihályi a flow egyik alapjának tekinti önmagunk és cselekvéseink felett gyakorolt kontrollt - mégis, nálunk a válaszok nem csekély hányada csoportosult kontrollvesztés, az én elveszejtése kapcsán átélt élmény-érzéshez.

Fölmerült bennünk a kérdés, hogy mennyire generáció-specifikus ez az élménykereső attitűd? Tudjuk, ez az első generáció, melynek valamilyen választ kell tudnia adni a bőség kihívására, de ettől még a környezet felől áramló élmények nem csak minket, hanem szüleinket is érnek. Mennyiben más az élménykeresésünk, illetve mennyire más típusú élményeket keresünk? Természetesen ez a kutatás generációs összevetésre nem alkalmas, hiszen csak a nyolcvanas években születettekkel interjúztunk. Másfelöl, hipotézisként megfogalmazható - a józan eszünket és a jóindulatunkat alapul véve -, hogy amennyiben kutatásunkat kiterjesztettük volna a korosabb generációk irányába is, valószínűleg hasonló válaszokat kaptunk volna. Eltekintve talán az extrémitástól, egyik kategóriánk sem tűnik fiatal-specifikusnak. Sőt. És válaszul a generációnkkal kapcsolatban megfogalmazott kételyekre - laza kapcsolatok, felszínesség - elmondhatjuk, hogy éppen ellenkezőleg, nagyon is fontos élmény-alapot jelent a társakkal, közösséggel eltöltött idő, a beszélgetés, valamint a felszínesség ellen szól az élmény gazdagító, én-formáló erőként történő definiálása. Másfelől, igazat kell adni a túlzott individualitást - olykor önzőséget, öncélúságot - emlegető hangoknak is: az élmény minden válasz esetében valamiképpen az ego körül forgott, az én-nel kapcsolatban fogalmazódott meg; lehet, túlzott elvárás lett volna altruista válaszokat várni, mégis, meg kell említeni ezek hiányát. Mindenesetre úgy érezzük, akár további korosztályok, akár más szubkultúrák felé nyitás szempontjából, e téma számos kiaknázatlan lehetőséget rejt magában minden élmény-kutatás által inspirált kutató számára. 


\section{Babócsai Zsuzsa:}

\section{Érzelemkifejezés és a '80-as generáció}

Magamat nagyon érzelmes embernek tartom, könnyen és őszintén osztom meg a környezetemmel mi bánt, vagy mi lelkesít. Azonban azt tapasztaltam, hogy ez nem olyasmi, amit kortársaimtól tanultam el az óvodai-iskolai szocializáció során. Az érzelemkifejezés inkább egy olyan problémakör, amely egészében is érinti a társadalmat, de a 80-as generációt - számomra - kiemelten. Mert nem mindenkinek egyértelmű a sírás és a nevetés.

\section{A '80-as generáció}

Miért vagyunk mi 20 és 30 közöttiek különbözőek ebből a szempontból? Talán -többek között - azért, mert a gyermekkorunk a rendszerváltás környékére tehető. Az 1980 előtt születettek még voltak kisdobosok, úttörők, erősebb közösségi élmények kötötték össze őket kortársaikkal. Másik oldalról viszont egy olyan rendszerben éltek, amiben nem volt szabad bármit kimondani, vigyázni kellett a politikához kicsit is kapcsolódó történések érzelmi lereagálásával. De amíg érzéseik nem ebben az irányban találtak maguknak szelepet a külvilágba, hanem például a kóruséneklés keretei között maradtak, addig viszonylag szabadon, sőt, támogatottan szárnyalhattak.

A nálunk fiatalabbakat (vagy akár a 80-as évek szülötteinek fiatalabb tagjait is) már szokás Y generációként említeni, ezzel elsősorban számítástechnikai ismereteikre utalva. Mi is meglehetősen modernek vagyunk, egyik technikai újítás sem marad ki az életünkből, mi is posztoljuk a facebookon legújabb okostelefonunk fényképét. De számunkra ez még nem olyan magától értetődő, inkább tanult dolog. Az anyanyelvhez és az iskolában tanult idegen nyelvhez tudnám hasonlítani a különbséget. Az 1990 után születettek a legtöbb esetben már gyermekkorukban is rendelkeztek otthon számítógéppel, felső tagozatos korukban pedig már összesúgtak az informatikatanár háta mögött, ha valamit elrontott az új anyag szemléltetése során.

És hogy a technika közelsége mennyiben befolyásolja az érzelemkifejezést? Nem biztos, hogy fiatalabb társaink érzelmesebbek nálunk, de a számukra természetes és mindennapi internet adta lehetőségek egy valamivel személytelenebb közeget nyújtva egyszerübb kifejezést tesznek lehetővé. Mert ugye mennyivel könnyebb virtuálisan megbökni valakit, mint odamenni hozzá és a szemébe mondani, hogy vonzódunk hozzá...

És persze nem hagyhatjuk figyelmen kívül az aktuális „társadalmi divatot” sem; hogy milyen vélt vagy valós elvárásokat támaszt felénk a környezetünk. A 90-es évek szülöttei pedig az „emo-generáció”. Egy olyan közegben, ahol szinte mainstream irányzatnak szá- 
mít az emo, - amely az érzelmek kifejezését szorgalmazza - természetesnek tetszik, hogy még a magukat nem ehhez tartozónak vallók is elfogadhatóbbnak tartják, ha egy fiatal fiú könnyezik a haja alatt, mint akár már a mi korosztályunk is. A nemi szerepek elmosódásával pedig a nők érzelemkifejezése talán kissé visszaszorul, a férfiaké is elfogadhatóvá válik, így a különbségek csökkennek, összességében pedig fejlődhetnek emocionális képességeink.

Nehéz egyértelmủen belső dolgokat vizsgálni. Kutatásom legfőbb korlátja is a torz minta, mely abból fakad, hogy a kérdéseimre válaszolók már mind eljutottak az érzelemkifejezésben egy bizonyos szintre. Vagyis beszélnek (vagy ikszelnek) róla. 11 mélyinterjút készítettem változatos hátterủ fiatalokkal, az itt tapasztaltakat pedig egy online kérdőívvel próbáltam nagyobb mintán is alátámasztani, 154 válaszadóval.

Aronson ${ }^{1}$ elmélete szerint jobban szeretjük azokat az embereket, akikről úgy tudjuk, hogy kedvelnek bennünket. Talán tovább lehet ezt az összefüggést gondolni úgy is, hogy ha vannak, akik szeretnek minket, mi is képesek leszünk erre az érzelemre. Mintha valamiféle táplálék volna: ahogyan a növény átalakítja a napfényt a fotoszintézis során, mi is úgy alakítjuk másoknak átadható szeretetté a szüleinktől felénk irányuló „napsugarakat”. Miután a beszélgetések során igazolódni látszódott ez a feltevés, két kérdés formájában beillesztettem a kérdőívbe is. Arra voltam kíváncsi, hogy a szülők megölelték, megcsókolták-e egymást gyermekük előtt, illetve, hogy számára jelezték-e szóval iránta érzett szeretetüket. A kapott válaszokat összevetve az önbevalláson alapuló érzelemkifejezési szinttel egyértelmű és szignifikáns összefüggések látszódtak. A későbbi pozitív és negatív érzések kifejezésére erős hatással van, hogy milyen családban szocializálódtunk, milyen érzelemkifejezési mintát hoztunk magunkkal.

\section{Negatív érzések kifejezése}

A negatív érzések kimutatásával több gondunk adódik, mint a pozitívakkal. Hiszen a síró ember nem termelhet igazán hatékonyan GDP-t, így nem is olyan hasznos a társadalom számára, mint egy lelkes és boldog munkaerő. Így nemcsak a férfiak, de a nők esetében is kerülendő a szomorúság bármilyen formájú „képi” megjelenítése. Habár a szomorú arckifejezés felismerése akár tizedmásodpercekkel is tovább tarthat a ránk tekintő számára, mint más hangulatoké ${ }^{2}$, és ha fönökünk férfi, akkor jó eséllyel egyáltalán nem is azonosítja be a hangulatunkat helyesen.

Pedig a sírás például nagyon jó dolog. Robert R. Provine kutatása ${ }^{3}$ szerint a kommunikációt segíti azzal, hogy nyomatékot ad az arckifejezésnek. Egy könnymaszatos arcról a férfiak is könnyen azonosítják a szomorúságot, míg a digitálisan könnymentessé manipulált fotóról jóval kisebb eséllyel. A sírás olyasmi, amire büszkének kellene lennünk, hiszen - többek között - ez különböztet meg minket más állatoktól. A sírás Provine szerint evolúciós lépés, melyet például az is bizonyít, hogy a csecsemők sem hullatnak eleinte könnyeket, fejlődésük későbbi szakaszában jutnak el erre a pontra. A mentális

\footnotetext{
${ }^{1}$ Aronson, Elliot: A társas lény, KJK-KERSZÖV, Budapest, 2004.

${ }^{2}$ J. Antonio Aznar-Casanova kutatása (http://www.physorg.com/news164434052.html)

${ }^{3}$ http://borsa.hu/siras-kepessege-20100401 (az Evolutionary Psichology cikke alapján)
} 
feszültség levezetése nyilvánvalóan pozitív hatással van az egészségünkre, de egy japán kutatás ${ }^{4}$ szerint még az immunfunkciókat is javítják az érzelmi indíttatású könnyek. Kísérletükben latex-allergiásoknak vetítettek egy megható jelenetet a Kramer kontra Kramer címü filmből (rejtély számomra, hogy ez miért hangsúlyos) és a könnyező alanyok bőre jobban reagált az allergizáló anyagra, mint a kontroll-csoporté (nekik egy időjárásról szóló bejátszást volt szerencséjük megtekinteni). A filmválasztás kiemelése mellett meglehetősen különlegesnek találom a latex-allergia és a könnyek lehetséges összefüggésének felvetését, mely a szóban forgó japán kutatókat már-már „brit tudós” szintre emeli. Ettől függetlenül fontos eredmény, mely általánosítva a sírás biológiai, egészségügyi hasznát bizonyítja.

Kérdőívem alapján világosan látszik az a nem túl meglepő tény, hogy a nők többet sírnak. William H. Frey statisztikái szerint egy átlagos nő havonta 5,3 alkalommal, míg átlagos férfitársa 1,7-szer fakad sírva. Az én válaszadóim 12,3\%-a viszont szinte sosem sír. A férfiaknak csaknem 23\%-a tartozik ebbe a kategóriába! További 27\%-uk pedig csak akkor engedi el magát, ha megbizonyosodott róla, hogy senki nem látja. A 20 és 30 közötti férfiak felét tehát soha nem láthatjuk sírni. Habár férfi interjúalanyaim arról számoltak be, hogy ez a titkolózás csak a saját, valós problémák által kiváltott könnyekre vonatkozik. Egy megható film (Kramer kontra Kramer?) vagy egy különösen mélylélektani regény, egy jól eltalált karácsonyi ajándék őket is megríkatja, és bár a moziban igyekeznek halkan trombitálni a zsebkendőjükbe, alapvetően nem szégyellik a meghatódottságból eredő könnyeket. (Az említett „emo-generáció” hatása lehet, hogy ez egyre elfogadottabbá válik.)

Női kortársaik viszont akár nyilvánosan is elsírják bánatukat, és nem csak a hozzájuk közel állók előtt szivárognak. 35,7\% vallotta, hogy előfordul vele, hogy a sírás nyilvánosan éri utol. Egyébként a közvetlen baráti vagy családi környezet 45,5\%-unk könnycsatornáiban jelez szabad utat, és ez az arány nem tér el jelentősen a férfiaknál és nőknél! Érdekes itt megemlíteni, hogy az interjúk alapján az derült ki, hogy az 1980-as évek generációjának lelki szemetesládája már nem a származási családban keresendő, hanem egyre inkább a párunkat és közeli barátainkat jelöljük meg támaszunkként. Biztató továbbá, hogy beszélgetőtársaim 3-4 ilyen bizalmas barátról beszéltek. Ha ez a szám a valós átlagot tükrözi, akkor szerencsésnek mondhatjuk magunkat, hiszen az idősebb korosztályok látszólag nem ápolnak ennyi szoros barátságot.

Habár a sírás még mindig kellemetlen a környezet számára, a depresszióval szemben egyre elfogadóbbak vagyunk. Interjúalanyaim egyöntetủen normális állapotnak tartják, amennyiben ideiglenes, és többségük már maga is átélt olyan időszakot, melyet a depresszió címkéjével illetett. Lehet, hogy csupán definíciós kérdésről van szó, és a depresszió elfogadása valójában csak a szó hétköznapivá tételét jelenti, az orvosi értelemben vett, valós mentális betegséget takaró állapottal pedig ugyanúgy békétlenek maradtunk. De mi már a pszichológus segítségét is elfogadhatónak és hasznosnak tartjuk, így biztosabbnak tűnik a szemléletbeli változás. Vagy talán pont azért legyintünk manapság a szó hallatán „majd elmúlik" kiáltással, mert nem akarunk tudomást venni a problémáról? Korábban elvárt

\footnotetext{
${ }^{4}$ http://borsa.hu/siras-kepessege-20100401

${ }^{5}$ http://borsa.hu/siras-kepessege-20100401 (William H. Frey, Muriel Langseth: Crying: The Mystery of Tears, Winston Press, Minneapolis, 1985. alapján)
} 
volt a gyász, tágabb értelemben bármilyen szomorú eset meggyászolása is, napjainkban viszont a szenvedőnek a felejtést javasoljuk egy fergeteges buli keretében, vagy a munkába temetkezve. Így próbáljuk kezelni az általunk depressziónak nevezett állapotot. Thomas Szasz ${ }^{6}$ szerint különben sincsenek mentális betegségek, csupán az aktuális társadalmi normák határozzák meg, hogy mit fogadunk el és mit medikalizálunk.

Az biztos, hogy ördögüzésre már nem küldenénk azt, akinek kiszalad a száján egy cifra káromkodás. Ez ugyanis - főként a fiatalabb generációknál - már erősen az elfogadható kategóriába esik. A stresszel magyarázzuk ugyanis, amit pedig oly mértékben az életünk részének tartunk, hogy már nem is a megszüntetéséről, hanem a kezeléséről folynak diskurzusok. Interjúalanyaim némelyike bevallottan ideges autóvezető, aki nem riad vissza az autóstársak verbális szidásától, bár a kézjelekkel történő kommunikációt már nem tartják szép gesztusnak. Aki pedig nem vezet, vagy nyugodtan teszi ezt, az is elnéző az üvöltöző soförökkel szemben, mert „hát stressz alatt van”. És ha valami elfogadhatóvá válik egy bizonyos szituációban, akkor az idővel teret nyer az élet más helyzeteiben is. Így vált hétköznapivá a trágár kifejezések használata. A 20-30 évesek (33,7\%-uk) kötőszóként, vagy nyomatékosító jelzőként is használják idegességük szintjétől függetlenül. Köztünk csak $7,1 \%$, aki minden helyzetben kerüli az általa káromkodásként ismert beszédformát.

\section{A kultúra fogyasztása és az érzelmek közötti összefüggések}

Úgy vélem, a kulturális fogyasztás is egyfajta kifejeződése belső érzésvilágunknak. Így interjúalanyaimmal a zenéről, könyvekről és filmekről, színdarabokról is beszélgettem. A zenében aktív szereplőként is részt vevők egyértelműen használták is erre a célra hangszereiket, vagy hangjukat. Ilyenkor nem is az a fontos, hogy az adott zenemü milyen hangulatú, csupán az az érzés, hogy ők csalják elő azokat a hangokat. A passzív zenehallgatás esetében viszont már tudatos választás következménye a lejátszóban forgó lemez hangulata. Van, aki rosszkedv ellen pörgős zenét használ orvosságként (a kérdőívre válaszolók 42,2\%-a), mások pedig direkt lehangolt állapotukkal megegyező zenét választanak (50,6\%), és akad néhány ember, aki szereti csendben végigülni depressziós perceit. Interjúalanyaimmal próbáltam megfejteni, hogy a sötét hangulatot erősítő zene hallgatásának mi lehet az oka. Úgy vélték, hogy valamiféle sorsközösséget éreznek az adott szám szerzőjével, előadójával. Nem érzik magukat olyan egyedül, ha hallják, hogy nem csak számukra szenvedés (aktuálisan) az élet. Volt, aki szerint pedig minden élethelyzetnek megvan a maga varázsa, és ő bizony szereti a szomorúságot is „kiélvezni”, a hozzá illő zene pedig a belesüppedést segíti.

A 80-as generáció ugyanazokon a kötelező olvasmányokon nőtt fel, mint a megelőző és a fiatalabb generációk. Saját választásaink viszont eltérnek más korosztályokétól. Leginkább elgondolkodtató műveket olvasunk, amelyek ugyan nem szájbarágós, leíró formában, de érzelmesek. A mélylélektani mondanivaló a sorok között található. Ugyanakkor szükségünk van némi pörgésre is, szeretjük a történetmesélős, kalandos regényeket (föleg

${ }^{6}$ Szasz, Thomas: The myth of mental illness: Foundations of a theory of personal conduct. Paul B. Hoebher, New York, 1961. 
a férfiak). És többet olvasunk, mint azt gondoltam volna. A kérdőívet kitöltők csak úgy ontották magukból a kedvenc írókat (csak 16,2\% ugrotta át a kérdést), sokszor magaskultúrába besorolt könyvek szerzőit is. És köztük jó arányban magyar írók és költők is szerepeltek. (Többekben felmerült például Márai Sándor, Ady Endre, Örkény István, József Attila, Jókai Mór, Rejtő Jenő, Wass Albert, Madách Imre, Csáth Géza, Mikszáth Kálmán neve.) A legnépszerűbbek azért a 20 és 30 közöttieknél is a bestsellerek szerzői, mint Dan Brown, J.K. Rowling vagy Douglas Adams. De ebből a kategóriából is láthatóan a kalandos történeteket mesélő írók vonzanak minket, és kihagyjuk a romantikus, csöpögős szerelmi regényeket. Bár sokan sokfélét olvasunk, a mintázat azt mutatja, hogy fontosnak tartjuk az érzelmek megjelenését egy jó könyv esetében, de nem szeretjük, ha azok teljesen átveszik a vezető szerepet a történetben.

A kedvenc színészekre azért voltam kíváncsi, mert az ő foglalkozásuk lényegében az érzelmek megjelenítése. Az érdekelt, hogy az 1980 és 1990 között születettek vajon milyen típusú színjátszást tartanak jónak, mennyire várják el az életszerűség jegyében az érzelmek kifejezését. Az interjúk és a kérdőívek alapján is úgy tűnt, nem annyira a nagy gesztusokat, részletes mimikát alkalmazó színészek a kedvenceink, hanem azok, akik inkább a „szemükkel játszanak”. Nagy öregeket kedvelünk (Morgan Freeman, Robert DeNiro, Jack Nicholson, Anthony Hopkins, Tom Hanks, Rudolf Péter), akik már sokféle filmben, színdarabban megmutatták magukat és bizonyították nekünk, mennyire sokszínủek - ez ugyanis fontos szempont számunkra. Az egyik legnépszerűbb filmszínész Leonardo DiCaprio. Öt hősszerelmesként láttuk gyermek- és tinikorunk határán a Titanicban, talán még első szerelmeink is ezen mozielőadás alatt szövődtek. Felnőve viszont már nem az ilyen típusú filmeket, nem az ilyen színjátszást tartjuk értékesnek, így Leo képét is sokan leszaggatták szobájuk faláról. Ezek után viszont még nagyobb értékkel bírt számunkra új arca, új filmjei. A skatulyából való kitörőt többre értékeljük, mint azt, akit mindig is sokoldalú színészként tartottunk számon.

\section{A politika érzelemkiváltó ereje}

Ha érzelmeket kiváltó tényezőkre gondolunk, nem mehetünk el szó nélkül a politika mellett. Annál is inkább, mivel ezen a területen a korosztályunkat sok támadás éri. Azzal vádolják a 20 és 30 év közötti fiatalokat, hogy nem elég szenvedélyesek politikai fronton, nincsen valós meggyőződésük, vagy nem fejezik ki azokat - nem járnak szavazni, nem beszédtéma társaságban. Kérdőívem tanúsága szerint valóban 24,1\%, aki teljesen közömbös, ha aktuálpolitikára gondol. (Ez azonban nem feltétlenül jelenti azt, hogy nem kíséri figyelemmel, illetve nem megy el a választásokra.) Az interjúk alapján egyébként az derül ki, hogy a közömbösséget megelőzi egy kiábrándulás, egy hosszú ideig tartó negatív érzelmi túlcsordulás. A kérdezettek több mint felénél beindítanak valamilyen érzelmi válaszreakciót az aktuális politikai történések: hol dühöt, keserüséget, máskor örömöt, lelkesedést. 25,3\% csak bosszankodni tud, csupán negatív érzéseket vált ki belőle az aktuálpolitika. A 154 válaszadó egyike sem állította, hogy csakis pozitív érzéseket váltana ki belőle! $\mathrm{Az}$ érdektelenség, érzéketlenség vádjával tehát nem illethetnek minket e téren, mert nagyon is odafordulunk a politikához, ráadásul komoly kritikusai is vagyunk. 


\section{Az öltözködésben kifejeződő érzelmek}

A hazaszeretet külső megjelenésben is kifejezők tették ki a kérdőívet kitöltők csaknem harmadát (31,2\%). A többség azonban úgy gondolja, hogy ezt a belső érzelmet nem kell mutatni mások számára, vagy nem az öltözködés ennek a megfelelő megjelenési formája. Anélkül, hogy a témában állást foglalnék, érdekes az az összefüggés, melyet e kérdés és a külföldre költözési hajlandóság között találtam. A trikolorba szívesen öltözőknek ugyanis 25\%-a már tervbe is vette, hogy idővel az országon kívül keresi boldogulását, és csupán 14,6\%-uk tartja valószínütlennek ennek a bekövetkezését. A többiek (a kérdezettek 68,8\%-a) esetében csak 19,8\% tervezi a jövőjét külföldön, 25,5\%-uk viszont nem hiszi, hogy adódna olyan körülmény, amely miatt úgy döntene, máshol próbál szerencsét.

Egyébként nem csak az érzelmeink befolyásolják az öltözködésünket, hanem a ruhánk színe, stílusa is lehet hatással a hangulatunkra, arra, hogyan érezzük magunkat. Ez persze leginkább a nők esetében igaz. (A férfiak többnyire a szekrényben éppen felül lévő tiszta ruhát veszik fel. Habár öltönyben mind másképp érzik magukat, mint hétköznapi öltözetben, és egyik beszélgetőtársam szerint már egy póló és ing között is érezhető a különbség, tudniillik egy ing „elegántosabb, még ha le is van hányva”.) Női interjúalanyaim ugyanis a felvetett kérdésen elgondolkodva arra jutottak, olykor nem tudatosan, de a hangulatuknak megfelelő színű ruhát választják, vagy - ahogyan a zene esetében láthattuk - éppen színes ruhákkal próbálják kompenzálni rosszkedvüket. Szerintem ennek azért lehet pozitív hatása (a színterápia elméletén túllépve), mert a környezetünk számára vidám képet mutatunk magunkról egy színes ruhadarabbal, így jó kedélyű emberként viszonyulnak hozzánk. Mert biztosan sokunkkal előfordult már, hogy egy fáradtabb arc, vagy kócosabb haj miatt a nap folyamán többen is rákérdeztek szomorúságunk okára, miközben mi teljesen jól éreztük magunkat. A sokadik kedves érdeklődő után viszont már kezdtük elhinni magunkról, hogy boldogtalanok, vagy legalábbis csúnyák vagyunk. Ez pedig tudatosan, vagy félig-meddig ösztönösen irányítva visszafele is müködhet. A narancssárga pulóverünkre mosolygótól talán nekünk is jobb kedvünk kerekedik.

\section{Érzelmek az internet világában}

A mosoly ugyanis még mindig nagyon pozitív visszajelzés számunkra, de napjainkban sokszor inkább smileynak \{szmájli\} hívjuk és meglehetősen sárga. Az online kommunikáció ugyanis egyre nagyobb teret nyer generációnk életében: a távolságok áthidalására használhatjuk, így tartva a kapcsolatot rokonainkkal, barátainkkal; de napjainkban már egy irodán belül, vagy akár egy kollégiumi szobában is gépelve folyik az egymás közötti eszmecserék egy része. Élőbeszédben számtalan más módja is van az érzelmek kifejezésének, mint az egyértelmű arckifejezés (könnyhullatás, vagy x-be torzuló szemvonal és kivillanó fogsor). Az írott szöveg esetében viszont nincs lehetőség játszani a hanglejtéssel, hangerővel, testbeszéddel, gesztusokkal, finom mimikával. Ezeket pótolják a kis sárga arcok, amelyek korlátozott grafikai megjelenésük miatt szélsőségesítik a megjeleníteni kívánt érzelmeket. Így az volt a hipotézisem, hogy a többség a valóságban nem nevet, amikor ilyen jeleket használ, hanem csak beszélgetőpartnere megnyilvánulásaira próbál reagálni, vagy saját mondatait egyértelműsíti. A kérdőív alapján viszont - bár a tendencia látszik -, meglepően sokan tényleg nevetnek a gép elött ülve $(35,7 \%)$. Az interjúk során az derült 
ki, hogy ők ezzel együtt kevesebb smileyt is használnak, tehát csak akkor jeleznek vele, ha a képernyőn látható arc kifejezése valóban megegyezik az övékével.

Az online társasági élet nagy színterei még a közösségi oldalak is. Üzenőfalaikon gyakran láthatjuk, hogy egy-egy ismerősünk a világ tudtára adja aktuális hangulatát, legbelsőbb érzelmeit. Az online kérdőívet kitöltők fele időnként maga is él ezzel a lehetőséggel, $3,9 \%$ pedig rendszeresen posztol ilyen bejegyzéseket. Bevallottan ez csak a kérdezettek $11 \%$-át zavarja, a maradék $35,1 \%$ pedig soha nem tesz ilyet, de nem is zavarja, ha más igen. Mindezek alapján úgy tủnik, hogy igen elfogadóak vagyunk azokkal szemben, akik nálunk jobban, gyakrabban fejezik ki érzéseiket. A beszélgetések fényében viszont élek a gyanúperrel, hogy ez csak az első reflexválaszunk. Persze, toleránsak és elfogadóak vagyunk, mert az a helyes. De amikor konkrétabb szituációk átgondolására kértem az interjúalanyokat, többen rájöttek, hogy mégsem örülnek túlságosan a munkahelyen sírva fakadó kolleginának, vagy a pár órája megismert ölelgetőnek. Állítólag a szomorkodóknak is vigaszt nyújtunk, de leginkább csak akkor, ha az illető közel áll hozzánk, vagy konkrétan kéri a segítségünket. Egyik 21 éves férfi beszélgetőtársam pedig azt mondta, megvigasztalná a körülötte bánkódót, de még nem fordult elő, hogy valakit komolyan szomorúnak látott volna.

\section{A legpozitívabb érzelem}

Végül a legmélyebbnek tartott érzelem egyértelműen a szerelem. Ha érzelemkifejezésről esik szó, sokaknak rögtön a szerelmi vallomás ötlik az eszébe. Bármennyire fiatal korosztályról is van szó, akik modern, emancipált világban nőttek fel, azért még tendenciaszerủen tartja magát a férfiak elsőbbsége az udvarlás ezen pontján. A kérdőívet kitöltő férfiak 35,7\%-a minden párkapcsolatában elsőként mondta ki az olykor meglehetősen misztifikált „sz-betűs szót”. A női válaszadók esetében ez az arány csak 10,7\%. Mindkét nemnél a delikvensek csaknem fele kezdeményező és kiváró pozícióban is volt már valamelyik kapcsolatában. Ebben azért látszik, hogy javult a „nadrágot viselő” nők aránya az idősebb generációkhoz képest, hiszen minél régebbi korokra gondolunk vissza, annál kevésbé tünik elképzelhetőnek, hogy egy kisasszony vallja meg legbelsőbb érzéseit a neki tetsző úriembernek. 7,1\% nyilatkozott úgy, hogy még sosem vallott szerelmet. De ez semmiképpen nem sugallja, hogy van egy szerelemre képtelen, vagy azt erősen titkoló réteg a 20-30 éves korosztályban. Ugyanis az adatokat a születési évvel összevetve jól látszik, hogy az élmény kimaradása csupán az életkorból adódik. Az említett 7,1\% mind az évtized második felében született. (Érdekesség csupán, hogy a szerelmet még nem vallók aránya legmagasabb az 1986-ban születettek körében, 16,2\%. Nem túl jó a kisugárzásunk.)

A legkülönlegesebb összefüggésnek a beszélgetések során az tünt, hogy a férfiak a pozitív, míg a nők inkább a negatív érzéseiket fejezik ki könnyebben. A kérdőívektől azt vártam, hogy számszerüsítve mutassák ezt a tendenciát. A valóságban azonban csak kisebb eltérés látszik a kérdésben, ráadásul pontosan ellentétes irányba mutat, vagyis a nőknek nagyobb aránya vallotta, hogy a pozitív érzésekkel boldogul könnyebben, míg a férfiak úgy ítélték meg, hogy számukra éppen ez a nehezebb. A férfiak egyébként inkább állnak hadilábon az érzelemkifejezéssel: 14,3\% választotta az „egyiket sem tudom túl jól kifejezni” lehetőséget. Ugyanezt a nőknek csak 4,8\%-a jelölte. 


\section{Összegzés}

A '80-as generáció sok tekintetben különbözik a fiatalabb és idősebb korosztályoktól. A vártnál, és más ez irányú kutatások eredményeinél kevesebbet sírunk, az viszont nem meglepő, hogy ezen belül is férfitársaink könnyeznek kisebb hajlandósággal. A depresszióval szemben ugyanakkor elfogadóak vagyunk, az interjúk során az derült ki, hogy nem annyira betegségként, inkább egy normális, ideiglenes állapotként tartjuk számon, melynek átvészelésére számos módszert ismerünk el. Így érzünk a stresszel szemben is, aminek egyik természetes szelepeként a káromkodást tartjuk számon, és ennek következtében korosztályunk harmada már a hétköznapi beszédben is használ trágár kifejezéseket. A zene segíti érzelemkifejezésünket és pozitív érzelmeket indít meg bennünk, illetve előmozdítja a negatív érzések feldolgozását. Ellenben a politika erősen negatív irányba tereli lelkivilágunkat, és a 20 és 30 év közötti kérdezettek egyike sem vallotta, hogy az aktuálpolitika kizárólag pozitív érzelmeket váltana ki belőle. A klasszikus kifejeződési formákon kívül az öltözködésünkkel is megmutatjuk mi zajlik bennünk: a válaszadók közel harmada ruházatában, külső megjelenésében is jelzi hazája iránti szeretetét. Az internetes érzelemkifejezés pótló jellege nem olyan erős, mint ahogyan gondoltam, hiszen a kérdezettek 35,7\%-a tényleg nevet minden alkalommal, amikor erre utaló jeleket használ. A közösségi oldalak üzenőfalain történő nyilvános érzelemkifejezés pedig csak 11\%-ot zavar. Így a vártnál megértőbb a generációnk azokkal szemben, akik gyakrabban vagy erőteljesebben nyilvánítják ki belső érzéseiket. A szerelmi vallomás pedig még mindig a férfiak reszortja, habár érzékelhető az egyenlővé válás ezen a területen is: a nők tizede minden alkalommal magához ragadja a kezdeményezést, és a férfiak és nők esetében is a kérdezettek fele váltogatja kiváró és kezdeményező szerepeit kapcsolataiban.

Annyi bizonyos, hogy mindkét nemnek van hová fejlődnie az érzelemkifejezés területén, és ez látszólag egy már beindult folyamat, legalábbis ami a fiatalabbakat illeti. Kérdéses, hogy a ' 80 -as generáció immáron felnőttjei tudnak-e, akarnak-e ilyen mély dolgokban változni. Vagy nem indul-e rossz irányba az érzelemkifejezés az által, hogy a stressz mindennapos és elfogadott jelenséggé vált, így az arra adott - nyilvánvalóan negatív - érzelmi reakciók is. És feltétlenül szükséges-e felszínre jutniuk és társadalmivá válniuk a pozitív érzéseknek, vagy elegendő, ha megmaradnak egyéni, belső szinten és valóban csak a düh és szomorúság számára keresünk kivezető szelepet? Kivesznek-e belőlünk bizonyos érzések az által, hogy az érzelmi élet kiélésére alkalmas mủvészeti vagy művészet közeli ágakat már csak kis arányban műveljük, és inkább csak passzív befogadói lettünk (nem írunk naplót, nem zenélünk)?

Kutatásom egy mozaikszerủ feltárás kívánt lenni, mely arra indít minket, hogy elgondolkodjunk a témáról. Az igazán fontos dolgok ugyanis kevéssé jól százalékosíthatók. 


\title{
Szabó Anita:
}

\section{A nemzeti identitás meghatározói az 1980-89 között születettek körében}

\author{
„Mindenkinek van identitása, \\ mely által kapcsolódni képes ahhoz a közösséghez, \\ amelyben él, samelyet maga is formál."
}

Schöpflin György

Ez az esszé arra a kérdésekre keresi a választ, hogy a 80-as generáció, hogyan élheti meg a nemzethez való viszonyát, kötődését, nemzeti identitását. Mindenekelőtt az a fó célom, hogy olyan mozgatórugókat, kiváltó eseményeket, szituációkat tárjak fel, amelyek meghatározhatják, hogyan alakulhat a kapcsolat egyén és nemzet, egyén és ország, valamint egyén és közösség között. Kutatásom során az identitás egy kényes szegmensét: a nemzeti identitást, a hazaszeretet érzését, honfitársakhoz való viszonyt tanulmányoztam egyetemisták, friss diplomások körében, strukturált interjú módszerével. ${ }^{1}$ Nem reprezentativitásra, hanem arra törekedtem, hogy egyéni tapasztalatok alapján olyan életfelfogásokat mutassak be, amelyeket akár modellértékűnek is tarthatunk, de legalábbis elgondolkodhatunk azon, hogy lehet másképp is szemlélni az ország jelenlegi/jövőbeni helyzetét, az életünk jelenlegi/jövőbeni alakulását.

Kiinduló hipotézisem az volt, hogy alapvetően különbözünk szüleink generációjától az államhoz, magyarsághoz való viszonyunkban, hiszen mi már demokráciában nőttünk fel, legtöbben (több) nyugati nyelvet beszélünk, majdnem mindenki képes magát megértetni angolul, ami egyet jelent azzal, hogy minden angolul beszélő személlyel; számos ösztöndíj és egyéb lehetőség adott a külföldi tanulásra, utazásra, barátszerzésre, kapcsolatépítésre, $s$ az Európai Unió nyújtotta lehetőségek is mobilizáltak bennünket. Interjúim alapján azonban arra jutottam, hogy a fiatalok bár élnek ezekkel a lehetőségekkel, mégis nagyon szoros szálak kötik őket Magyarországhoz.

\footnotetext{
${ }^{1}$ Összesen 10 személlyel készítettem 50-60 perces interjút, ahol előzetes olvasmányok alapján bennem megfogalmazódott kérdésekre kérdeztem rá. Az interjú során a személyes kérdésektől indultam, s a karriercélokon és az eddigi, főleg külföldi tanulmányúton szerzett tapasztalatokon keresztül, a határon túl élő magyarokhoz, más nációk tagjaihoz való viszonyon át, a szülők általuk tapasztalt nemzeti tudatát érintő, és egyéb alább olvasható kérdéseket tettem föl. A válaszokat diktafonnal rögzítettem, majd begépeltem.
} 
A megkérdezettjeim kiválasztása két kritérium alapján történt: 1980-1989 között születetteket kérdeztem meg, s ezen időintervallumon belül pedig olyan személyeket, akik legalább fél évet töltöttek külföldön. E második szempont Magyarországot más országgal, a magyar embereket más nációk tagjaival összevetni képes válaszadók miatt volt fontos. Szabó Ildikó és Örkény Antal a Tizenévesek állampolgári kultúrája című munkájának egy részlete is megerősíti eme feltevésemet, mely szerint: „A nemzeti hovatartozás kérdései rendszerint nem vagy csak alig vetődnek fel kiegyensúlyozott társadalmi körülmények között. Az egyéni és csoportos konfliktushelyzetekben azonban megnő e kérdések jelentősége, és képesek átszőni a magán- és társadalmi élet szinte minden dimenzióját, amennyiben a másik ember és a másik csoport percepciójának, a velük való kapcsolatok létesítésének és minősítésének az etnikai hovatartozás válik meghatározó elemévé.”

Egyik interjúalanyom, ezt így fogalmazta meg:

Szerintem valaki, aki Magyarországon él, az sokkal kevesebbet foglalkozik azzal, hogy ö magyar, mint az, aki egy sokszinü közösségben él, ahol ö a magyar; az egyetlen magyar, akit ismernek, akiröl kialakitják a véleményüket, akár egy egész országra kivetítve. $\left(X^{\prime} 87\right)^{3}$

Mi az, ami meghatározhatja az egyén nemzeti kötődését?

- család, otthoni légkör, diskurzus

- közösség, barátok véleménye, hozzáállása

- nevelés otthon és az iskolában egyaránt, ez a kettő együtt, hogyan hat az egyénre

- olvasmányok (iskolai, személyes érdeklődésből fakadóak)

- tapasztalatok -itthon, külföldön- pozitív/negatív

- lehetőségek / kilátások

- képzettség

- háttér (családi, szellemi), ez alatt értem a támaszt, a támogatást, háttértudást

Ezen felsorolt tényezők közül párat interjúválaszok alapján mutatok be, szemléltetve, hogy hasonló képzettség, lehetőségek mellett is mennyire más gondolkodásmódot ad a család, a szocializáció, valamint hasonló családi háttértől függetlenül mennyit számítanak a tapasztalatok, a képzettség, s az ebből fakadó lehetőségek.

Először arra kérdeztem rá, hogy mit értenek identitáson úgy általánosságban interjúalanyaim, általában mit tartanak fontosnak elmondani önmagukról, hiszen Frederik Barth szerint az identitás nem eleve adott dolog, hanem, többek közt, más etnikumokkal való interakció folyamatában változik. S e mellett még a Stachel-féle identitásfogalmat is szem előtt tartottam, mely szerint „Az identitás sokféle, ingatag, változékony, esetleges, töredékes, konstruált, egyezkedés során létrejövő, stb.” s ez természetszerűleg megköveteli, hogy ne várjunk el egységes, egybehangzó válaszokat. Az interjúalanyok szerint az identitás:

„Mindazon tulajdonságok, jellemvonások összessége, amiket fontosnak tartunk magunkban és döntéseink, cselekedeteink során figyelembe veszünk. "(X'85)

„Az identitás egyfajta kötödés valamihez/valakihez, amely ez által meghatározást ad az

\footnotetext{
${ }^{2}$ Szabó Ildikó- Örkény Antal: Tizenévesek állampolgári kultúrája. Minoritás Alapítvány, Budapest, 1998, 159 p.

${ }^{3}$ Interjúalanyaim anonimitását tiszteletben tartva, ugyanakkor jelezve nemüket és életkorukat, a következő jelölésmódot alkalmazom: X-szel jelölöm a női válaszadókat, Y-nal a férfiakat, s mellette születési évüket tüntetem föl. (Mintám:

X'89, X’88, X'87, X'85, Y’88, Y’88, Y’86, Y’86, Y’85, Y'82)
} 
embernek. Például az, hogy ELTE-s vagy, az azáltal, hogy a hallgatói jogviszonnyal és persze emocionálisan is kötödsz az ELTE-hez, meghatároz téged, mint egyetemi hallgatót és magyar állampolgárt is." (Y'88)

"Az identitás sokrétü és fontos dolog. Fontos és meghatároz az, hogy magyar vagyok a világban; az hogy budapesti vagyok Magyarországon, az hogy MCC-s vagyok az egyetemisták között. Ez által a nagyvilágban kötödéseket ad az embernek. Ez lehet, hogy kicsit bugyután hangzik, de hihetetlenül fontos, mert a kötödés értékekkel, közös értékekkel jár és ettöl lesz valaki felelös ember. Ha "világpolgár" vagy... annak nincsenek értékei, úgy mindent szabad..." (Y'88)

Az X'85-ös válaszadó azt sejteti, mintha mindig, minden körülmény között tudatosítaná, hogy ki is ő, és mit miért csinál, s önmeghatározáskor is erre helyezné a hangsúlyt. Ez azonban inkább csupán elméletben igaz. Az ezt követő két példa szerintem nagyon jól szemlélteti, hogy a mindennapi kommunikációban egyre fontosabbá vált a karrierrel, hivatással kapcsolatos meghatározások kiemelése, ha önmagunkról nyilatkozunk.

Ezt követően a nemzeti identitást meghatározó és formáló tényezőket vettem sorra.

"Nagyon meghatározó, hogy a családod hogyan vélekedik bizonyos kérdésekben" (Y'89)

A család az, ahova beleszületünk, nem választjuk. Ennek a nyelvét, szüleink értékrendjét sajátítjuk el először, később jön a megkérdőjelezés, a saját vélemény és preferenciák kialakítása. Ha honvágyunk van, általában nem elsősorban az otthon, mint szülőföld, hanem hátrahagyott emberi kapcsolataink hiányoznak.

Fontosnak tartom megmutatni, hogy miben vélik különbözőnek e korosztály gyermekei önmagukat, ha valóban eltérnek szüleik értékrendjétől.

- Te hogy érzed, szüleidhez képest máshogy vélekedsz az országról, magyarságodról, $s$ ha igen, miben?5

„Szerintem két komoly, egymással erösen összefüggö különbség van a 80-as és késöbbi, ill. az azt megelözö generációk között. Ez pedig a rendszerváltás. Egyértelmü, hogy a 80-as generáció az, aki elöször teljesen poszt-kommunista generáció. Mondjuk azt, hogy értelmes fél-felnött az 14 évnél kezdödik. Az 1980-ban született gyerekek 10 évesek voltak a független Magyarország kezdetén. Így bennük már lényegi nyomot vagy bármilyen nyomot nem hagyott a kommunista rendszer, nem voltak úttörök meg kisdobosok meg KISZ-esek, stb. Így, egyrészt nem tapasztalták meg a szovjetista diktatúra eszmeiségét, másrészt egy nyitott világba születtek, ahol már nem kérdés az utazás, az információszerzés nyugatról, stb... Így más a mi gondolkozásunk, másrészt talán picit egyszerübb elszakadni a magyarságunktól." (Y'88)

„Lényegében semmiben, max. hogy leginkább már demokráciában nöttünk fel." (Y'85)

„Sokkal nyitottabb vagyok, mint a szüleim, nehezen tudnám öket elképzelni, hogy külföldön éljenek, már csak azért is, mert ök csak a magyar nyelvet beszélik. Másképp szocializálódtak, őket arra nevelték, hogy tartsák meg a kapcsolatot az állammal, míg engem kevésbé neveltek erre, de alapvetöen nem gondolom, hogy hatalmas különbségeknek kellene lennie. "(Y'86)

„Nagyon-nagyon, gyökeresen máshogy viszonyulok, ök nem is gondolják végig, én nagyon

${ }^{4}$ A Mathias Corvinus Collegium tagja.

${ }^{5}$ A kövérrel szedett kérdések az interjú során föltett kérdéseim. 
tudatos vagyok, nagyon sok mindenben: meghúzom a vonalakat, végiggondolom, hogy mihez milyen a hozzáállásom, nemcsak hogy hogyan cselekszem. Az ö hozzáállásuk nem ilyen markáns, nincsenek határozott elképzeléseik az ilyen jellegü dolgokról."(Y'82)

Ezek a különbségek a mobilizációs szándékra, az új rendszer, az Európai Unió nyújtotta lehetőséghez, valamint a határon túli magyarokhoz való viszonyra vonatkoznak főként. Mást tanítottak az iskolában, más ünnepeken kellett részt vennünk, mint szüleinknek, ez mindenképpen lényeges különbség. Az államhoz való viszony ugyanakkor nem elsösorban generációs kérdés, ráadásul egy ember életén belül is változhat. Kiemelném itt Y'82 válaszát, mert ez az interjúrészlet kimondottan a történelmi múltról, a határon túli magyarokról való gondolkodásmódra utal. Ebben a múlt újrafelfedezése, a problémákról való nyílt beszédmód lehetősége és a cselekvés opciója is felmerül már.

- Mi az, ami ideköt? Mit tudnál kiemelni, ami miatt szeretsz itt élni, ami miatt szerinted jó magyarnak lenni?

„Mert itt születtem, itt él a családom, szép ország, kifejezetten sokszinü, nem szélsöséges földrajzilag és idöjárásilag. Budapest szép, nem túl nagy város, emberi léptékü, fejlödget. Lehetne gyorsabb ütemben is, de azért megyünk elöre." (Y'88)

"Nagy elöny, hogy tudod, hogy ki vagy, mit tehetsz meg, megvan a helyismeret és biztonságérzet, nagy elöny, hogy otthon van az ember. A viszonyokkal jó tisztában lenni, s ha elmész is bármikor vissza lehet jönni. Koncert, kedvenc együttesek, beülös helyek, emberi kapcsolatok, amik fontosak; hiába laza szálak, de azért vannak... Itthon tényleg hajlandóak az emberek beszélni magukról.

Budapest nagyváros, tudom, hogy mit hol lehet megvenni, mindennek a középpontja, azt tudom csinálni, amit szeretnék... ismeröseim is itt vannak." (X'88)

„A Túró Rudi miatt. A Duna parti séták miatt. Az izes káromkodások miatt. Péterfy Bori miatt. A Nagyi föztje miatt. A barátaim miatt. Az alföldi tanyák, a fürdök, a sok alkohol, a magyar designerek, Torgyán József, a szinházak, a piros csörü gólyák, a romkocsmák, a Petöf Rádió, a balatoni hekk, a napraforgók, az aluljárók, a kékfestö terítök, a kockás fülü nyúl, a panelhangulat, a Királyleányka, a metrós sütiillat, a citeraszó, a szecesszió, az arany fukszok, a vonatkocsik, a póni miatt. Ide tartozom." (X'89)

„Hazádon kivül más országban sosem leszel az adott közösség teljes körü tagja még akkor sem, ha tökéletesen beszéled a nyelvet, vagy ha a párod abból az országból származik." (X'85)

„Úgy neveltek fel, hogy magyarnak lenni jó, a szüleim is jobboldali beállitottságúak, nemzeti értékek védelme ehhez is kapcsolódik benne. Fiatalkori olvasmányok is formáltak, mint pl. a Parainesis - a reformkor szellemisége, hogy itt kell alkotnod, hatnod, gyarapitanod, csak itt lehetsz nagy." (Y'85)

„Itt nöttem fel, ide kötnek az emlékeim, itt van a családom, nagyon sok pozitiv emlékem van, nincs mitöl meneküljek, ezt nehéz lenne feladni... nagyon jó gyerekkorom volt. Nagyon szerettem a magyar vidéki életet, hogy nincs minden beépitve, hogy vannak kis falvak, vannak helyek, ahol még nincs internet. Szerintem ez is a báját adja Magyarországnak."(X'87)

Magyarországhoz ezer ok miatt lehet kötődni, $s$ ezekből szerettem volna egy kis ízelítőt adni. A legmeghatározóbb minden egyes interjúalanyomnál, az a család, valamilyen közösség, az érzelmi többletet adó dolgok voltak, s csupán ez után említettek bármi mást. 
- Szerinted az iskolának van szerepe a nemzeti identitás formálásában?

"Söt! Kulcsszerepe van. Hangsúlyt fektethet történelmi eseményekre, elötérbe helyezheti a kommunikációjában a "nemzeti sorskérdéseket". Nagyon fontos a tanterv, hogy mi kerül bele és mi nem. Egy gyerek személyiségének a kialakitásában jelentös szerepet játszik az iskola és a tanárok. Mind a személyes mind a nemzeti identitására igy nagy hatással van. Szerintem fontos, hogy egészséges nemzeti öntudatot tanitson egy iskola a tanulóknak. Nem kell NagyMagyarország tábort szervezni és ott nyereg alatt hüst pubitani meg visszafelé nyilazni, de igenis mutassa azt a képet az iskola, hogy büszkék lehetünk és legyünk is büszkék magyarságunkra. Nem érzem túlzásnak pl. azt, hogy az USA-ban a gyerekek minden reggel a zászló felé fordulva eléneklik a himnuszt." (Y'88)

„Ott lát mintákat tanártól, osztálytársaktól, sokan csak ott, otthon szinte egyáltalán. Illetve a tananyag, föleg a történelem, de az irodalom is ugyanilyen fontos. Az, hogy mit és hogyan tanitanak." (X'88)

Mivel a nemzeti nyelven történő olvasás eleve másfajta műveltséggel ruház föl - hiszen mást olvas a történelem és irodalom órán magyar kisfiú és mást a francia kislány -, így az identitásképző elemek átadásának mennyisége, formája az iskolában, alapvető befolyással lesz a felnőtt személy gondolkodásmódjára.

\section{- Mi az, amin változtatni lehetne?}

„A magyarokban nagyon-nagyon nincs önbizalom és nagyon-nagyon nincs büszkeség, akárhol is tartunk, örüljünk annak, ami van, hogy van mire büszkének lennünk. Nem érzem, hogy megbékélnénk a sorssal, elfogadnánk, ami van, és arra épitenénk."(Y'82)

"Jó lenne, ha lenne egy olyan elit, aki azt sugallja, hogy merjünk nagyot gondolni, hogy merjünk nagyok lenni." (Y'85)

„Mivel van bennem egy megváltói hajlam, hogy tegyük jobbá a világot, úgy érzem, ezt ott kell tennem, ahova születtem, és ez itt van. Nem tudjuk megváltoztatni a világot, ha mi sem változunk, és mi sem teszünk érte. El kell fogadni, hogy kis pontok vagyunk, de sok kis pontból majdcsak lesz valami. Fel kell rázni ezt a népet és ebböl nagy dolgokat lehet kihozni."(Y'82)

$\mathrm{Az}$ egyéni cselekvési hajlandóságot és motivációt hiányolják. Az elégedetlenség, a felelősség örökös áthárítása, valamint a búskomorság nagyon lehangoló. A beszélgetések alapján azt szürtem le, hogy a jelenlegi állapotokkal nincsenek megelégedve, s tettre-készek lennének beszélgetőpartnereim, ám szükség lenne egy náluk nagyobb erőre, hogy érezzék, ha tesznek valamit az nem hiábavaló, az valóban mindenkinek a megelégedésére lesz, a jelenlegi sokszor elkeserítő helyzet megváltoztatását szolgálja.

Valószínűleg sokan éreztük már azt külföldről hazatérve, hogy egy bizonyos sokk ért minket, amikor bementünk egy boltba és nem mosolyogtak ránk, nem köszöntek kedvesen, vagy felszállva egy tömegközlekedési eszközre lökdösődést érzékeltünk az előzékenység helyett, vagy ha netalán nem találtunk valamit s útbaigazítást kértünk mogorván néztek ránk, és még sorolhatnám. Beszélgetőpartnereim a figyelmességet, a kedvességet, a pozitív hozzáállást hiányolják itthon. Persze ez csak egy általánosítás, de mégis megfigyelhető. Nagyon sok kedves, figyelmes, előzékeny ember él Budapesten és az ország többi részén is, csak sokszor a mindennapos rohanás, a gondok nem engedik ezt a felünket kibontakoztatni. És akkor még csak az egymással való kapcsolatunkról szóltam és nem 
említettem meg a turistákat, akik véleményem szerint jogosan csalódottak, nem értik, hogy az emberek miért nem válaszolnak, miért nem segítenek. Szegények nem tudják, hogy sokan valóban segítenének, csak nem tudnak pl. angolul, vagy nincs helyismeretük, vagy egyéb okból kifolyólag.

A „magyar mentalitásnak” nevezett viselkedésformát is szinte minden interjúalanyom súlyos problémának, megváltoztatandónak tartotta, problémának abból a szempontból, hogy az általános közérzetet rombolja, ha az emberek nem kedvesek, segítőkészek, nem mosolyognak, nem vidámak, nem fognak össze a közös célért, az irigykedés, áskálódás, megkeseredettség pedig megmérgezi az emberi kapcsolatokat.

$\mathrm{Az}$ „Azt kell erösiteni, ami van” mondat véleményem szerint hazaszeretet, tenni akarást, elkötelezettséget tükröz. Tudjuk, hogy vannak értékeink, amikre büszkének kell lennünk, $s$ nem szabad hagynunk, hogy az idő feleméssze őket, elő kell venni ezeket az értékeket, javítani, fejleszteni, erősíteni kell, büszkének kell lennünk rájuk. Ahhoz tudnám hasonlítani országot, nemzetet érintő véleményeket, mint a szülő gyermekhez való kapcsolatát. Az egyén felelősnek érzi magát érte, tesz annak érdekében, még áldozatokat is vállal, csakhogy a maximumot hozza ki belőle. Ez ebben az esetben ugyanakkor kétirányú folyamat, egy ágens ehhez nem elég, $s$ az ország esetében még a kettő is kevés. Összefogásra, a közös cél felismerésére, és ezért tenni akarásra, tettrekészségre is szükség van. A kétirányú folyamat alatt azt értem, hogy bizonyos mértékben kell egyfajta támogatás az állam részéről, hogy a javító szándékot véghez tudja vinni az egyén.

A közösségi összetartozás-érzés egy jól megnyilvánuló formájára is rákérdeztem:

- Rubik-kocka, C-vitamin, aranycsapat és még sorolhatnám. Rájuk miért vagyunk büszkék? Mit mozgatnak meg?

„Sok sportnál szokták mondani, hogy nem hobbi, hanem életforma, ott már ez is jelzi, hogy ez mennyire fontos az ember énképében, hozzátartoznak a pozitiv kulturális/ történelmil politikai örökséghez." (Y'86)

„Azok a nemzetközi események hihetetlen mennyi ember ki tudnak vinni, ahhoz képest milyen keveset sportolnak hihetetlen mennyien mennek ki, föleg ha van esélye, hogy elérnek valamit, hogy nyernek. Külföldön is mennyi magyar szurkoló van, egy közösségi élmény, ha valamilyen válogatottunk nyer, összetartozás-tudatot teremt az emberek között"( $\left.Y^{\prime} 86\right)$

„Ö is területileg itt él, ugyanazt a nyelvet beszéli, nagyjából ugyanabban a környezetben él. Annak az elismerése, h ebböl a környezetböl ki tudott nöni."(Y'88)

Fontos, hogy legyen valami, amivel azonosulhatunk, ami pozitív csoportszintű összetartozás-tudatot generál, ellentétben azzal, mintha valamivel szemben határoznánk meg önmagunkat egyéni és csoportszinten. A pozitív nemzettudatnak ez a fajta büszkeség alappillére, $s$ egy picit sajátunknak is érezzük a másik ember sikerét, s ez jó érzéssel tölt el.

Arra is kíváncsi voltam, hogy mit láttak, mit tapasztaltak külföldön, miért tartják vonzónak.

„Több a lehetöség, jobbak az egyetemek, munkahelyek, nyugatabbra általában kedvesebbek az emberek. Leginkább a gazdasági fejlettségböl adódó dolgok." (Y'88)

„A kulturális eltéröség miatt, az újdonság miatt jó élni „kint”. Emellett vannak olyan kül- 
földi helyek, amik jelen pillanatban sokkal jobb fejlödési-boldogulási lehetöségeket kinálnak, mint a kelet-közép európai Magyarország vagy bármely környékbeli ország."(Y'82)

„Európa mégiscsak egy közös kulturális-történelmi alapra épül, így a mobilitás egyszerübb Európán belül. Ha ki megy az ember New Yorkba, minden más, nagyon más. Ha ki megy Londonba, Brüsszelbe, Berlinbe, Amszterdamba, akkor más a tömegközlekedés, más a bolt, más a pénznem, más a nyelv, de mégis egyúttal hasonló az egész." (Y'88)

Tehát a magasabb életszínvonal, sokszor pozitívabb hozzáállású emberek, a lehetőségek, amik esetleg itthon nem adatnak meg, ezek vonzanak külföldre. S ne felejtsük el azt sem, hogy a változatosság gyönyörködtet.

$S$ mindezeken túl:

- Hol képzeled el a jövődet? Hol szeretnél letelepedni, családot alapítani? Gondolkodtál már ezen?

„Hosszú távon mindenképp Magyarországon szeretnék élni. Magyar vagyok ez fontos, ezen nem is tudok változtatni, ez felrubáz egy csomó olyan elönnyel, amivel a nem magyarok pl. nem rendelkeznek. Tudom, hogyan müködnek a dolgok, itt tényleg otthon vagyok, tudom, mi a dörgés, milyen nyelven beszélnek az emberek, hogy értik meg egymást, hogy kell kezelni öket, és ez óriási magabiztossággal ruház föl." (Y'82)

„Lehetöleg Magyarországon szeretnék maradni. A következö években lehet, hogy kiutazom külföldre, tanulmányutakat fogok tenni, de alapvetöen Budapesten szeretnék élni. Tényleg nem tudom, lehet, hogy miután kimegyek külföldre, ott is maradok, bármi lehet. De egy biztos: a gyerekeimet - bárhol élek, és akárki lesz a feleségem - magyarnak fogom öket nevelni. A feleségemnek is meg kell tanulnia magyarul, nem lesz könnyü, de próbálkozunk vele, ha szeret, akkor megteszi. Nagyon fontos a nevelés kérdése, hogy a magyar identitást mennyire plántáljuk gyermekeinkbe, akár itthon, akár külföldön."(Y'85)

„Most külföldi ösztöndijjal tanulok, de az egyetem elvégzése után Budapestre húz a szivem, ott szeretnék letelepedni barátommal együtt." (X'85)

Az a válaszadóm, aki tartósan elmenne, azt a lehetőségek hiánya, életvitele, életfelfogása, státusából fakadó hátrányok miatt tenné. Ha itthon nem ismerik/fogadják el, elítélik, ellehetetlenítik, ha olyasmit akar tanulni/ csinálni, amit itthon nem lehet, pl. nem oktatják, vagy nem elég magas színvonalon azt, ami őt érdekli, vagy ha pl. nincs olyan nép, szokás, vallás, állat, növény, technológia, stb. amit kutatni akar, akkor az elég erős motiváció az egyén számára, hogy más országban keresse a boldogulását. De az, aki lát maga előtt célt és önmegvalósítási lehetőséget itthon, nem hagyná el hosszú távon szülőföldjét. Hosszú távon az 5 évnél tartósabb külföldi munkavállalást értették megkérdezettjeim.

$S$ az utolsó dolog, amit ebben az esszében fontosnak tartok még leírni, ha szóba kerül a nemzeti identitás, nem hagyhatjuk figyelmen kívül az ezzel ellentétes folyamatokat sem.

- Szerinted a globalizáció, az univerzális lehetőségek, a multikulturalizmus mennyiben gyengíti a nemzethez való kötődést?

„A globalizáció azt sejteti az emberekkel, hogy a világ minden pontján otthon érezhetik magukat, pedig ez teljesen lehetetlen, hiszen hazád csak egy van, és egy helyen találod meg 
a gyökereid. Nincs annál szomorúbb, mint olyan fiatalokat látni, akik a világot járva teljes gyökértelenségben, identitásukat elvesztve próbálnak magukra találni."(X'85)

„Persze rengeteg szokást felveszel, de ami mást látsz, jobban megkülönböztet tölük. Aki nem volt külföldön nem biztos, hogy látja, hogy miben magyar, mert kell valami viszonyítási alap, amihez képest meghatározza magát."(Y'86)

Tehát a tapasztalatokból az szűrhető le, hogy nem veszítjük el gyökereinket, sőt egyes alkalmakkor, mint pl. egy Erasmus ösztöndíj esetében, a nemzeti jellegzetességek tesznek érdekessé, ezek különböztetnek meg egy látszólag ugyanolyan diáktárstól. Többen is megemlítették az Erasmuson szokásos nemzeti esteket, ahol minden náció tagja hagyományos nemzeti ételt készít, $s$ ilyenkor nem ritka, hogy a cserediák életében először készíti el azt. Ekkor ismét kiéleződik, hogy milyen szokások jellemeznek bennünket, mert ami itthon természetes volt, az külföldön közelről sem az.

Bízom benne, hogy az interjú-részletekkel sikerült átadnom a kutatás során tapasztalt optimista életszemléletet, és azt a mértékű racionális gondolkodásmódot és jövőképet, azt a fajta hazaszeretet érzését, ami példaértékủ lehet. Ha egy szóval kellene jellemeznem mindazt, amit interjúalanyaimnál tapasztaltam, ez a szó a hazaszeretet lenne. Mindez azért is lényeges, hiszen véleményem szerint megcáfolja a fejekben élő sztereotípiákat. Interjúalanyaim szeretnek Magyarországon élni, hosszabb távon jövőjüket is itt képzelik el, a társas kapcsolatok, a haza iránti vonzalom és tisztelet erős ragaszkodást eredményez körükben. Ugyanakkor valamelyest megcáfolódott hipotézisem, melyben azt állítottam, hogy lényegesen különbözik a 80-as generáció szülei generációjától.

Hasonlóan mindenki máshoz, a 80-as években születettekre is nagy hatással volt szüleik szocializációja, ugyanis ha nem is teljesen ugyanazokat, de nagyon hasonló értékrendet közvetíttetek gyermekeik felé, mint amit ők kaptak, amiben felnőttek. Természetesen igazodtak a kor lehetőségeihez, de nem olyan mértékben, mintha teljesen magukénak érezték volna őket. És szerintem az is sokat számít, hogy amikor gyermeket vállaltak még a lehetőségeik változatlanok voltak, csak a gyerekek iskolás korára következtek be a jelentősebb változások. Már a 90-es években születettek is jóval nyitottabbak, egy újabb kor gyermekei, mindezek ellenére úgy gondolom, hogy az igazi váltás valószínűleg olyanok körében lesz megfigyelhető, akiknek szülei már az összes lehetőség birtokában szocializálódtak, összes lehetőség tudatában terveznek és vállalnak babát, úgy nevelik gyermekeiket. Tehát a nagyobb áttörés a 80 -as vagy későbbi generáció gyermekeinek körében lesz, hiszen mi (a szerző 1989-es születésű) már demokráciát, szabadságot, korlátlan lehetőségeket szívtunk magunkba, és egy ilyen életszemléletet közvetíthetünk gyermekeink felé is.

Remélhetőleg a 80-as évek szülöttei ennek az új korszaknak a szellemiségében fogják állampolgári jogaikat gyakorolni, a közösségi életben részt venni és annak aktív formálóiként fognak más korok gyermekeivel összefogva egy olyan Magyarországot megteremteni, melyben minden egyes generáció megtalálja számításait. 


\section{Laposa Richárd-Schneider Géza:}

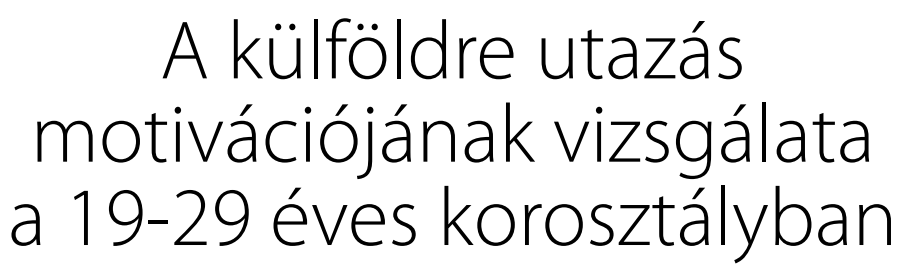

A nagy inaktivitás és a fiatal munkaerő fogyása jelenti az egyik legnagyobb problémát hazánkban. Ráadásul sok tehetség külföldön keresi a boldogulást. A hazai foglalkoztatási ráta alacsony. Az Európai Unióban sereghajtók vagyunk. Míg a munkanélküliségi mutatók átlagosak. A diplomás fiatalok nagy része későn, 30 éves kora körül lép ki a munkaerőpiacra, sokuk ráadásul valamelyik uniós tagországban keresi a karrierépítés lehetőségét. Jelenleg több százezer ilyen fiatal lehet, és ha a tendencia tovább folytatódik, drámaian lecsökken a rendelkezésre álló, képzett fiatal munkaerő.

A nyelvtudás, magabiztosság, nyitottság. Aki fiatalként hosszabb időre külföldre megy tanulni vagy dolgozni, ilyen előnyökkel jöhet haza. A munkaadók szerint jól mutat az önéletrajzban a külföldi tapasztalat, de természetesen ez nem elegendő a teljes sikerhez.

A kutatásunk célja a külföldre utazás motivációjának vizsgálata volt a 19-29 éves korosztályban. Ez alatt a munka, tanulás vagy külföldi élet céljából való utazást értettük. Arra kerestük a választ, hogy mennyiben igazolódnak be az előzetes várakozások? Magatartást, viselkedést, szellemi beállítottságot, hozzáállást, viszonyulást vizsgáltunk.

A '80-as generáció kultúrája és életperspektívái olyan fontos kérdés, amivel foglalkoznunk kell, már csak a korcsoport kulcsszerepe miatt is. Az ország későbbi demográfiai helyzete is indokolja ezt, hiszen 20-30 éven belül a népesség öregedése és a csökkenő számú dolgozó, a romló függőségi arány mellett igen nehéz helyzetet fog eredményezni, amit még súlyosbíthat az ország rövidtávú kvalifikált munkaerö-vesztése.

Mi az, ami segíti, vagy hátráltatja a mai huszonéves generációt a boldogulásban, mik a problémái, életstratégiai?

Ez a korosztály igen bonyolult, úttörő helyzetben van jelenleg Magyarországon, mivel ez az első posztszocialista generáció. Ez felelősség és lehetőség is egyben.

A meg nem élt, de átörökített traumák és a választási lehetőségek sokasága, a bizonytalanság, a mintakövetés problémája.

Ján Figel', az oktatásért, képzésért, kultúráért és ifúságért felelős európai biztos nyilatkozata: „A tanulási mobilitás hasznos mind az egyének, mind az iskolák, egyetemek és oktatási intézmények, illetve az egész társadalom számára. A tanulási mobilitás segit a készségek, a nyelvtudás és az interkulturális kompetencia megszerzésében, valamint lehetöséget nyújt mind az egyének, mind a cégek számára az innovációra, továbbá arra, hogy helyt álljanak a nemzet- 
közi versenyben. Támogatnunk kell a mobilitást, hogy a külföldi tanulás vagy munkavégzés ne kivételes, hanem általános eset legyen. Mindez nem csupán az unió gazdasági fellendülésének fenntarthatósága és erössége szempontjából fontos, hanem a 21. század európai társadalmainak társadalmi kohéziója szempontjából is.

Az EU mobilitási programjai számos területen segítik a fiatalokat. Ennek ellenére a külföldi tanulás vagy munkavégzés inkább kivételes, mint általános országunkban. Egyetemi vagy főiskolai hallgatók számára jobban elérhető, mint másoknak. Az EU a mobilitási lehetőségeket fejleszteni szeretné: olyan különböző tanulmányi területeken, mint például általános- és középiskola, felsőoktatás, szakmai képzés, szakmai gyakorlat, gyakornokság és önkéntes munka. Továbbá elég csak a közös történelmi múltra emlékezni: egész Európában általános volt az oktatási és munkavállalási célú mobilitás a középkor során. Erre a fajta mozgásra ismét nagy szüksége van Európának.

A többség a jobb kereset reményében - kényszerüségből vagy több pénzre vágyva megy külföldre munkát vállalni. Mindenesetre a külföldi munkalehetőség a legfontosabb szempontok között szerepel. A fiatalokat leginkább az idegen kultúrák felfedezése, új emberek megismerése, a tapasztalatszerzés, a nyelvtudás fejlesztése vonzza.

Egyesek nem találják a helyüket ebben az országban. Ez elkeserítő? Az itthoni fizetésekből szinte lehetetlen elkezdeni egy életet, nagyon nehéz otthont teremteni. Mindemellé a hazai munkavállalók csapdahelyzetként felfogható kondíciókkal hirdetnek meg álláslehetőségeket a pályakezdők számára. Így még a kevés elérhető, de rosszul fizető álláslehetőség is gyakorlatilag elérhetetlen sokak számára. Továbbá korosztályunk olyan korosztály, mely képes volt Magyarországon talán elöször stabil és mennyiségben is jelentős külföldi kortárscsoportokkal kapcsolatok kiépítésére. Az általuk megismert külföldi és az általunk tapasztalt hazai helyzet közötti igen jelentős (például anyagi) különbség a következő, mely felveti a magyar fiatal fejében a külföldre utazás, vagy költözés lehetőségét. Ez elkeserítő.

Kutatásunk aktualitása ellenére, szeretnénk az alábbi szövegrészletet mindenki figyelmébe ajánlani:

„Igaz, hogy Magyarország nem tudja eltartani valamennyi tehetségét és ezek közül sokan külföldre kényszerülnek boldogulást keresni. De ebben a szomorú megállapításban már benne rejlik az, amin tulajdonképpen örvendeznünk kellene. Az, hogy nálunk aránylag sokkal több a tehetség, mint például a nagy Németországban; hogy Magyarország ma már nemcsak a tokaji bor, hanem egyszersmind a sok tehetség hazája. De minden kis országnak közös sorsa, hogy nem tudja eltartani valamennyi tehetségét, annál fogva, mert kisebb a tehetséget méltatni tudó publikuma és kevesebb teret nyújthat az érvényesülésre, mint a nagy országok. Még a vagyonos és a civilizáció magas fokán álló kis északi országok tehetségei is ugyancsak rászorulnak Németországra. Még a francia művészet is elmegy publikumért Oroszországba, Amerikába, sőt a Balkán vidékére is. [...] Ez még nem volna olyan nagy baj. A kis országokra nézve még egy kis nemzetgazdasági előnyt is jelent, ha a tehetségei vagyont szereznek az idegenben $s$ vagyonszerzés után hazatérnek, a munkájuk gyümölcseit élvezni. Magukra a tehetségekre nézve se csupa megpróbáltatás a külföldön való kalandozás. [...] Aki ott ragad, ahová a vándorútja vezette és végképpen elszakad Magyarországtól, az vagy ritka, szerencsétlen kivétel, vagy olyan valaki, akit csak 
a születéshely véletlene füzött előbb Magyarországhoz, akiért tehát nemigen lehet nagyon bánkódni.” (Ambrus Zoltán: Ah, a külföld Nyugat 1912. 1. szám)

Lássunk egy másik, jellemző véleményt ebben a témakörben, mely nem nevezhető mainak, de az írás születése óta talán (ebből a szempontból), mintha nem is telt volna el majd egy évszázad:

„Mert nem bírunk kigyógyulni abból a magyar betegségből, hogy semmi se imponál nekünk, ha itthon találjuk, ellenben leborulunk minden előtt, ami a külföldről jön és még a legjelesebbjeinknek is külföldről kell hozniok szolgálati bizonyítványt vagy ajánlólevelet, ahhoz, hogy komolyan vegyük őket és elismerjük a tehetségüket." (Ambrus: 1912b)

A kutatás során több lehetőséget is mérlegelnünk kellett.

Először eszközt kellett választanunk, olyat, amely a vizsgálati céljainkkal a lehető legnagyobb összhangban áll. Ilyenkor a szociológiában két fó út közül lehet választani: az egyik inkább a mennyiségi, míg a másik inkább a minőségi oldalt ragadja meg. Ha minőségi elemzést végez a kutató, akkor az interjúzáshoz fog hozzá. Ez egy olyan beszélgetést jelent, mely a kérdezettből a lehető legmélyebb megértés érdekében a kérdezett társas viszonyaira, társadalomban elfoglalt helyére, a rajta átvonuló történelemre és ezeknek egyéni, emberi megélésére kíváncsi. A mennyiségi oldal pedig a számszerüsíthetőséget tartja szem előtt, elsődleges eszköze a kérdőíves adatfelvétel. A kutatás itt a standardizálható válaszokra és a statisztikailag alátámasztható összefüggésekre kíváncsi, amik alapján egyszerübb vagy bonyolultabb kapcsolatot keres bizonyos társas jelenségek között, ezt több lépcsőben éri el. Mi a mennyiségi oldalra voltunk kíváncsiak, hiszen a nyolcvanasok külföldre utazásának motivációs vizsgálatához véleményünk szerint ez illett a legjobban, mert bár nagyon sokan tartoznak ebbe a körbe, mégis első kézből szerettünk volna biztos adatokhoz jutni tőlük. Így kérdőívezésbe fogtunk bele. Kutatásunk jóval inkább egyfajta feltáró jellegű tapogatózás volt, mint sem biztos összefüggések felállitása. Leírásként is felfogható eredményekre jutottunk, de semmiképpen sem törekedtünk biztos magyarázatokra.

A kérdőívek lekérdezése sosem egyszerű feladat, ennek is több útja van. Lehet (általában postai) önkitöltős, vagy kérdezőbiztossal megtámogatott formájú. Mindkettő előnyök és hátrányok sokaságával bír.

Nos, haladva a korral és az Y generációs szemléletet előkapva, mi az internetet vettük segítségül a kutatásunkban: azaz online kitölthető kérdőívet használtunk. Ennek több előnye is megvan: gyors, olcsó, könnyen hozzáférhető. Gyors, hiszen az e-mailen és a különböző közösségi site-okon és levelezőlistákon körbeküldött kérdőívek akár két napon belül is kitöltésre kerülhetnek, továbbá mivel egy kattintás után már tölthető is a kérdőív, ezért a válaszadási arány is igen jó. Olcsó, hiszen gyakorlatilag nincs anyagköltsége, nincs szállítási költsége, ahogyan kérdezőbiztosok fizetségére sem kell ilyen esetekben gondolni. Könnyen hozzáférhetőségére pedig már utaltam. Ugyanakkor hátrányokkal is bír: az internet alapvetően csak bizonyos kör számára érhető el még ma is, akiket pedig nehézkes homogén jellemzőkel bíró csoporttá fogni össze. Továbbá a kérdőív továbbításának módja lehatárolja annak kitöltői körét is. A kérdéseket a lehető legegyértelműbben kell megfogalmazni, hiszen a kitöltő mellett nem állhat ez esetben képzett kérdezőbiztos, ami szintén egy hátránya. Mint láthatjuk, az interneten kitölthető kérdőív egy igen megfontolandó és óvatosan kezelhető, ám mégis müködőképes munkaeszköz. 
A kérdőívben próbáltunk - mint egyszer már említettük - a lehető legegyértelműbben fogalmazni és képileg is félreérthetetlenné tenni azt. A kérdéseket a lehető legrövidebbre fogalmaztuk meg, ahol lehetett és állító formában (azaz nem használtunk tagadó típusú kérdést, hiszen az könnyedén vezethet félreértelmezéshez). Továbbá csak olyan kérdéseket tettünk fel, melyekre a kérdezettek biztosan tudnak választ adni. Ugyanakkor arra is vigyáztunk, hogy a kérdés ne tartalmazzon sugalmazást, azaz ne tartalmazzon egy szándékot, egy rávezetést semelyik válaszlehetőségre.

A kérdések legtöbbje egy válaszlehetőség választhatóságával bírt. Ennek talaján igennem párostól a tízfokú skálázáson át a táblázatba szedett azonos válaszlehetőségű, de eltérő kérdésekig használtunk nagyon sok itemet (kérdőív-elemet), mindezt a fent már említett célok mellett a kérdezett figyelmének életben tartása érdekében is - látni kell, hogy élménytársadalomban élünk, ahol a figyelem fenntartását a változatossággal és gyorsasággal lehet és kell megközelíteni.

A kérdőív nagyjából fele szólt a kérdezett demográfiai jellemzőiről: nem, életkor, családi állapot és hasonlók. Míg a kérdőív második fele magáról az utazásról, pontosabban a kérdezett külföldhöz és küldre utazáshoz való viszonyulásáról szólt. A demográfiai rész a kérdezettek csoportba sorolásához kell, míg a második rész a tulajdonképpeni motiváció tárgya. Ám mindkettőre szükség van, hiszen a motivációt valakik érzik valami iránt. Attitűdvizsgálatot folytattunk. A vizsgálatban részt vevő személyeknek a vizsgálat tárgyával kapcsolatos beállítódást, ezt kifejező véleményeiket tártuk fel. A szociális attitűdben az egyén értékrendje tükröződik. Érzelmi, gondolati, és az ezekből eredő viselkedési összetevői vannak. A szociális attitűd nem maga a nyílt viselkedés, hanem annak élményháttere.

A felmérés tehát interneten folyt le, ennek köszönhetően nem léptek fel finanszírozási nehézségek sem. A felmérés összesítve 187 föt ért el, ám mivel a kutatás célja nem a reprezentativitás volt, hanem pusztán egy körkép készítése a témában, egy leíró jellegü vizsgálat született, melynél nem kerülhet elő (jelen esetben) a mintavételi hiba sem. Már csak a következők okán is.

A lekérdezettek közé azok juthattak be, akik felé el tudtuk szórni a kérdőívet, azaz közösségi oldalak, levelezőlisták és hasonló csoportok tagjainak volt esélye mintába kerülni. De, mint már említettük, nem volt célunk - sőt, forrásunk sem - egy reprezentatív kutatás lefolytatása. Továbbá az alappopuláción kívül nem igazán volt mintavételezési értelmü egyéb kategóriánk. A területi szempontok épp ezért nem kerültek elő, de a benyert adatok alapján egyértelmű Budapest és agglomerációjának dominanciája a mintában. A később közölt adatok az összes megkérdezett véleményét tükrözik majd. Az adatfelvételre 2010. október 24. és október 28. között került sor.

Az eredmények azonban még egyszer hangsúlyozandó: nem tükrözik a teljes generáció véleményét, abból egy szeletet mutatnak fel, így egyfajta betekintést nyújtva a kérdéskörbe.

A mintába 69 férfi és 118 nő került be, többségük a korosztály fiatalabbjai közül: az átlagéletkor 22,76 év, a leggyakoribb válaszadók a 23 évesek voltak. Jelentős többségük egyedülálló (106 főt jelent), míg a második leggyakoribb párkapcsolat és élettársi viszony 71 fővel, a házasok és a különélők száma elhanyagolható a korosztályban, összesen tíz ember. Hasonló arányokban van jelen a végzettség is. Valamivel több, mint 100 fó végzettsé- 
ge eddig középiskolai, a fennmaradók egyetemet vagy föiskolát végeztek. Az édesapa/családfenntartó végzettsége magasabban kvalifikáltak felé húz: a válaszadók több, mint fele jelölte apját föiskolát végzettnek, negyedük érettségivel végzett középiskolát, maradékuk anélkülit jelölt, három fó 8 osztályt. Ez azt is jelenti, hogy bár felfelé mobil csoportot sikerült elérnünk, ám ez a mobilitás eleve magasabbról indul, mint ami megszokott a mai viszonyok között. Erre a mintavételezés nehézsége ad választ. A kérdezettek kevesebb mint fele budapesti, harmaduk egyéb városból jött, faluról 11,2\% származik, megyei jogú város pedig a mintába kerültek 8\%-nak lakóhelye. Ezt árnyalja, hogy a kérdezettek több mint háromnegyede a Központi Régióból származik, azaz Pest megyében vagy Budapesten lakik, tehát fôvárosi, vagy agglomerációs lakosság, az ország legjobban menő térségéből, legkedvezőbb gazdasági alaphelyzetből. A legtöbben jelenleg tanulnak, de vannak akik szellemi foglalkozásúak, vagy vezető beosztásúak, ám ez nem annyira gyakori. Az édesapa foglalkozásánál a leggyakoribb válasz a szolgáltatói, majd a vezető értelmiségi, amit az egyéb szellemi foglalkozások követnek, ezt követi 15\%-al az ipari és építőipari foglalkozás, majd az inaktív családfó. Ha az anyagi helyzetet nézzük - ezt egy tízfokú skálán kellett jelölni - akkor tipikus kép áll elénk: mindenki középre húzódik, ám mégis inkább a hatos a leggyakoribb, ez egy középosztálybeli jelenség: a válaszadó nem akar sem túl szegénynek, sem túl gazdagnak tűnni, így inkább közép felé tart a véleménye. Továbbá az elhelyezés függ a referenciacsoporttól is, azaz, hogy kikkel méri össze háztartása anyagi helyzetét.

Mindezt röviden összefoglalva tehát megkérdezettjeink többségükben olyan fơvárosi, vagy Pest megyei, középosztálybeli vagy kicsit jobb módú családból származnak, ahol az anyagi helyzet kedvezőnek mondható, a családfenntartó képzettebb és munkaviszonyát a szolgáltatás és szellemi típusú munkavégzés határozza meg. A kérdezettek többnyire a generáció fiatalabbjait teszik ki, tanulnak még, a bolognai rendszer első diplomájának megszerzésén fáradoznak, egyedülálló nők. Ez a kérdezettek legnagyobb százalékát kitevő csoportokat jelenti. Ez a kérdezettek legnagyobb részének jellemzését adta, de persze koránt sem a teljes képet.

A válaszadók jelentős többsége tehát nő volt. A háztartások anyagi háttere egyenletes eloszlást mutat. Átlagéletkor: 23 év. Többségük egyetemista, tanuló.

Faktorelemzés (értékek). A faktorelemzés során több változót, értékeik együtt járása okán képesek voltunk statisztikai eszközökkel kevesebbe összefogni, így bizonyos kép alakult ki arról, hogy milyen alapmotivációk indítják a mintába került korosztálybelieket külföld felé. A következő faktorokat találtuk, melyeket a belölük kiolvasott leglényegesebb tartalom nevével címkéztünk meg:

1. anyagi jólét - törekvés

2. munka öröme - érdekes élet

3. önállóság - előítéletmentesség

4. család biztonsága - boldogság

És ehhez jön még az értelem és társadalmi megbecsültség, ám ezek önmagukban sehová sem sorolódtak igazán nagy erővel.

A következő faktorelemzés más oldalról közelítette meg a külföld tematikát. Itt már két fö vonalba lehetett süríteni a véleményeket, melyeket alább látható módon neveztünk meg. 
1. Keresleti lehetőségek - esély elhelyezkedni - befogadóbb társadalom

2. Tanulási lehetőség - tapasztalatszerzés

Itt pedig a közbiztonság válaszlehetősége nem sorolt igazán sehová sem.

Aki karrierlehetőségeit itthon rossznak ítélte, az inkább szeretne külföldre menni dolgozni. Ez megfelel előfeltevéseinknek. A karrierlehetőségek megítélése relevánsan rosszabb itthon, mint külföldön - ezt feltételeztük - és visszaigazolódott. Demográfiai dimenziók mentén azonban nem érdemes bontani az összefüggést, az összefüggés fennáll korosztály egészében, férfiaknál és nőknél is.

Aki nagy jövedelemmel lenne elégedett, az szívesebben menne külföldre. Ez is megfelel a várakozásainknak, mindehhez karrierlehetőségeit karakteresebben rosszabbnak ítéli meg, a nagy jövedelemelvárás egyébként Magyarországon irreális összegek megjelölését jelentette. Öt válaszkategóriával dolgoztunk, ebből a pályakezdőként 350 ezer forintos fizetés és a fölöttiekben reménykedők értendők ide. Az országban erre gyakorlatilag nincs mód.

Kereseti lehetőség, elhelyezkedés a fó motiváló erő, amikor a külföld szóba kerül; a tanulási lehetőség e mögött másodlagos, és kevesekre terjed ki lehetőségében is. Az egyetemek által kínált (pl. Erasmus-jellegü) külföldi tanulmányi jellegü tartózkodást nyújtó lehetőségek száma nagyjából egybevág a már kint tanult kérdezettek számával a mintában. Több mint figyelemre méltó a következtetés: tanulmányi „élménytúrákat” leszámítva a magyar fiatalok nem mernek belevágni külföldi egyetemek képzéseibe tömegesen. Ez viszont az Európai Unió piacain hátrányként jelenhet meg, hozadékai okán.

Magyar jelleg a boldog család központba helyezése, annak ellenére, hogy sok statisztika rácáfol erre. Ez is jellemzője a társadalmi működésnek: papíron és névtelenül legtöbbek az elvártnak vélt választ jelölik meg, vagy az érvényben lévő társas normák értéktartalmának megfelelő választ, de a valóság sokszor szembesít minket azzal, hogy bár mindenki tudja, minek és hogyan kellene zajlania, mégis teljesen másként cselekednek a valóságban. Így ez a kiértékelt adatokból szép és kellemes eredménynek tünik, mégsem vagyunk bizonyosak benne, hogy a kérdezettek valós társas cselekvéseinek tükrét mutatná.

A domináló szociális attitűd a törekvő értékek mentén szerveződik meg. Tehát azok, akik jelenünk tipikus törtető, célorientált, modern fogyasztói értékek mentén szerveződő gondolkodását követik.

A megkérdezettek angol és német nyelvterületre utaznának legszívesebben. Kisebb említésben, de megjelent még Spanyolország és Japán is, ami azonban inkább egzotikusságának és hazánkban beszivárgó kultúrtermékeinek tulajdonítható. Egyértelmű azonban, hogy az Egyesült Államok és Nagy-Britannia mint angolszász területek még mindig dominálnak a magyar fiatalok számára. Ehhez zárkózott fel Németország, ami szintén érthető, hiszen az Európai Unió egyik, ha nem a legfontosabb motorját adó ország. Ami még ide vonatkozhat az az, hogy korosztályunk nyelvismerete döntően az angol nyelvre korlátozódik, kisebb részét a német nyelv adja. A többi - akár csak európai - nyelv tulajdonképpen említésre sem érdemes. Véleményünk szerint ez a rendszerváltás utáni szűk nyelvoktatási paletta eredménye, illetve az akkori közgondolkodás túlzott egyirányúsága (az angol nyelvterületek vélt vagy valós, de túlzott dominanciájának érzete irányába).

A nyitott kérdésünk megérne egy másik kutatást: „Szerinted mi a legfontosabb pálya- 
kezdéskor?” Itt annyi, és olyan sok típusú válasz született, melyek közül sok kiértékelése elvinné a kutatás fókuszát, ugyanakkor a magyar fiatalok munkavállalással kapcsolatos hozzáállását igen jól bemutatná. Ezért erre a részre csak kisebb részben térünk ki.

A hazai munkaerőpiac negatív sajátosságaként emelik ki azt, hogy mindenhol fiatal pályakezdőket keresnek, de több évnyi tapasztalttal A leggyakoribb kellemetlenségként említették meg, hogy szinte minden munkakör betöltése több évnyi gyakornoki tapasztalat betöltését igényli. E mellé általános válasz az, hogy a kapcsolati tőke fontosabb, mint a képzettség, ami akár az előbbi pontot megadni, vagy felülírni is képes. A képzettség országunk intézményeiben egyébként is túlzottan formális és elmélet-központú. Szinte mindenki és szinte minden képzési területről több gyakorlati típusú tudás megszerzését tartaná kívánatosnak. A diploma azonban a kitöltők szerint kezdi értékét veszíteni, mindamellett, hogy egyre általánosabban elvárt feltétele egy munkakör betöltésének. Nagy igazság, hogy a tömeges felsőoktatás sokkal inkább a fejkvótára megy rá, mint az oktatás minőségére - vélik a válaszadók.

Úgy gondoljuk, hogy sikerült felmérnünk és átfogóan bemutatnunk témánkat. Rávilágítottunk a folyamtok általános érvényére. Olyan magatartásformákat találtunk, amik alapján érdemes tovább vizsgálódni. Úgy gondoljuk, hogy ez a téma igen fontos és aktuális, érdemes volt a feltárásra, további kutatást igényel és nem csak szociológiai jelentősége miatt.

\section{Források:}

Ambrus Zoltán: Ah, a külföld Nyugat 1912. 1. szám

(Jobpilot.hu A tehetséges fiatalok külföldre kacsingatnak 2007. november 14.

Monster.hu Mire jó a külföldi ösztöndíj a karrierépítésben 2010. október 12.

ELTE Online A '80-as generáció életperspektívái 2010. november 4.

Ec.europa.eu Európai Bizottság 2009. Július 8.) 


\section{László Johanna:}

\section{A közösségiség \\ és az átmenet generációja}

\section{Hogyan változott meg a közösségiség fogalma a szocializmus felbomlását követően?}

Ha azt a szót hallom, hogy nemzedék, mindig magasztos dolgok, ikonikus alakok jutnak az eszembe: a márciusi ifjak vagy a nagy generáció, a hatvanas évek fiataljai. Mikor a nemzedékekről tanultunk, illett olyanokat mondani, mint például a kohorsz - vagyis olyan emberek csoportja, akik egy-egy demográfiai eseményt nagyjából azonos időben éltek át. A születési kohorsz kifejezést használtuk a közel azonos évben születettekre.

A nemzedék és a generáció szavak a születési kohorsznál valahogy romantikusabban csengtek számomra. Élményeket, emlékeket sejtettem mögöttük: mint amikor „a nemzedék tagjai" elmennek egy harmincéves érettségi találkozóra, és nosztalgiáznak, sztorizgatnak. Mesél valamit az egyik, és a többi az első mondat után tudja, hogy hogyan folytatódik a történet, hiszen közösek az emlékek, ők is valami hasonlót éltek át akkoriban.

Tudom - tanultuk ezt is persze -, hogy én is besoroltattam valamilyen nemzedékbe. Töprengtem azon, hogy mi lehet az a közös, ami minket, nyolcvanas években születetteket összeköt. Jó lenne nagyot mondani: például, hogy mi teremtettük meg a világbékét vagy követeket küldtünk a Marsra.

Aztán arra gondoltam, inkább kérdezősködök, a nyolcvanasokat faggattam a közösségröl1.

\section{A módszerek}

A témához nem illettek a számadatok és a mutatók, ezért kvalitatív utakat választottam: vizsgáltam a szakirodalmat és mélyinterjúkat készítettem négy nyolcvanas években született fiatallal, melyek során a közösségi élményeik és a közösséghez füződő viszonyuk érdekelt.

Mindezek alapján jelen munkámat három fö részre tagolom: elsőként a szocializációs színtérről beszélek, majd a közösség fogalmáról, végül a nyolcvanasokról, akiket az átmenet generációjának nevezek.

\footnotetext{
${ }^{1}$ Köszönettel tartozok az interjúalanyaimnak, valamint az '50-es, a '60-as és a '70-es években született A.-nak, M.-nek és R.-nak, valamint a Kontra Műhelynek, hogy inspiráló ötleteikkel gazdagították a munkámat, hogy kötetlen beszélgetéseikkel segítettek összeterelni a kósza gondolataimat! Jelen írás lezárulta: 2010. 11. 28.
} 
Ez az írás, nem reprezentatív kutatás eredménye, hanem egy olyan „minivizsgálaté”, amivel az elgondolkodtatás a célom.

\section{"Sors, nyiss nekem tért"}

Mielőtt belevetnénk magunkat a közösség fogalmának vizsgálatába, röviden beszélnünk kell a szocializáció folyamatáról, s ennek megvalósulási helyeiről, az ún. szocializációs színterekről.

A szocializáció voltaképpen egy tanulási folyamat, melynek során elsajátítjuk szűkebb és tágabb környezetünk (a családunk, a baráti körünk, a társadalom etc.) értékeit, normáit, a környezetünkben uralkodó nézeteket, attitűdöket, azaz a szocializáció folyamán formálódik a gondolkodásunk, a világlátásunk is.

Vagyis a szocializáció:

„a közvetlen környezetbe, a mindennapi életviszonyokba való bevezetés folyamata, melynek során az emberi személyiség kialakul. A személyiség fejlödését alapvetöen meghatározó környezeti hatásokat túlnyomórészt nem tudatosan feldolgozó folyamat. Ennek során elsajátitásra kerülnek mindazok a szerepek, értékek, viselkedések, illetöleg képességek és ismeretek, amelyek azokra a csoportokra jellemzöek, ahová tartoznak, vagy ahová tartozni szeretnének. "2

E folyamat közegei az ún. szocializációs színterek. Ezek közül elsődlegesnek a családot tartja a szakirodalom, másodlagos szocializációs színtér az iskola, harmadlagos pedig minden egyéb: a kortárscsoport, a munkahelyi vagy szabadidős közösség stb.

Ha a színterek térbeli megvalósulása szerint kell differenciálnunk, a fizikai színterek mellett (családi otthon, az iskola épülete, a kedvenc klub, ahova beülünk etc.) az internethasználat terjedésével és a gép előtt töltött idő növekedésével egyre nagyobb jelentőségre tesznek szert a virtuális felületek, fóként a közösségi portálok.

Egy másik csoportosítás szerint elkülöníthetjük egymástól a természetes és a mesterséges szocializációs színtereket. Például az előbbiek közé tartozik a család, utóbbiakhoz sorolandók az ifúságügyi rendszer intézményei (ifjúsági irodák, ifjúsági pontok) stb.

Az egyén beilleszkedése, a fiatalok integrációja szempontjából kulcsfontosságú, hogy a szocializáció folyamatában hathatós segítséget, megfelelően adaptálható mintákat kapnak-e a környezetüktől.

Miután az 1989-es rendszerváltás, vagyis egy alapvető gazdasági és társadalmi átalakulás évtizedében született generáció e szöveg alanya, idekívánkozik Margaret Mead antropológiai vizsgálatainak egyik jelentős megállapítása:

„elhatárolta egymástól azokat a civilizációkat, amelyekben a változás annyira lassú, hogy a fiatalok számára az életükben szükséges tudásmennyiség és kultúrkincs gyakorlatilag születésükkor adott, illetve azokat, amelyekben a változás olyan gyors, hogy nemcsak a fiataloknak, de a felnötteknek is egymástól, a kortársaiktól kell elsajátitani azt az információmennyiséget és készségeket, amelyek jelen társadalmuk civilizációs, kulturális elvárásainak teljesitéséhez szükségesek (Gábor-Jancsák 2006: 446)’3

\footnotetext{
${ }^{2}$ Nagy G. [szerk.] (2008) Ifjúságügy. Ifjúsági szakmai, ifú́sági munka. Új Mandátum Budapest, p675

${ }^{3}$ László J. (2009) A háló továbbszövése. Az ifúsági irodák haszna különös tekintettel a reziliencia alakulására. In: Szabó Fanni [szerk.] (2009) Társadalmi tanulmányok. ELTE TáTK HÖK, Budapest, p154
} 
A nyolcvanasok és szüleik helyzete iskolapéldája ennek a felgyorsult változásnak, melynek során a fiatalabb generáció a társadalmi átalakulás miatt kevésbé építhet a szülők tudására, hiszen nemcsak a fiatalok, hanem a felnőttek is merőben új, és sosem tapasztalt viszonyok között találták magukat.

Ilyenkor pedig még inkább fölértékelődnek a kortársközösségből ellesett adaptációs minták.

Szükséges tehát egy rövid kitérő a közösség fogalmának vizsgálatára.

\section{Én, te, mi. Mi?!}

A szocializáció folyamata elválaszthatatlan a közösségtől, hiszen bár a szocializáció akkor is zajlik, amikor egyedül vagyunk egy szobában és olvasunk vagy tévét nézünk, ám időnk jelentős részét mégis más emberekkel töltjük, kölcsönös egymásra hatásban.

De hogyan jutunk el az egyéntől a csoportig, s milyen viszonyban áll egymással a csoport és a közösség fogalma?

A csoportot egyének alkotják, s a közösséget a csoportnál magasabb szintű jelenségnek tételezem. Vagyis írásomban a közösség fogalmát „minőségi csoport”“ értelemben használom, olyan közös normákkal rendelkező formációnak tekintem, amelynek tagjait kohéziós erő kapcsolja egymáshoz, és amely

„önjáró, közös tulajdonságokkal, értékekkel biró csapat, a csoporttá szervezödés legmagasabb minösége."

Létszáma nem határolható körül szigorúan, néhány főnyi ember, de egy társadalmi csoport is alkothat közösséget.

Roland L. Warren a közösség öt funkcióját emeli ki:

"1. A szocializáció, melyen keresztül a közösség bizonyos értékeket olt tagjaiba;

2. A gazdasági boldogulás funkciója - a közösség megélhetési lehetöséget biztosit tagjainak;

3. Társadalmi részvétel, teljesitve a társasági igény iránti általános igényt;

4. Társadalmi kontroll, megkövetelve a közösség értékeinek betartását;

5. Kölcsönös támogatás, mely folyamat segitségével a közösség tagjai megvalósitják azokat a feladatokat, amelyek túl nagyok, vagy túl sürgösek ahhoz, hogy egy egyedülálló személy kezelni tudja." 6

A közösség kapcsán meg kell említeni két, a fiatalok esetében különösen fontos formációt, a szubkultúrát és a kortárscsoportot. A szubkultúra a többségi kultúrától eltéro", sajátos normákkal rendelkező kultúra, mely kritikusan viszonyul a többségi kultúrához. Összetartás szimbólumai számos formában leképződhetnek: zenében, öltözködésben, viselkedésben stb. A kortárscsoport Giddens szerint a „hasonló korú és [...] státuszú egyénekböl álló baráti csoport" ", voltaképpen az egyén referenciacsoportja - vagyis ez jelenti a fö viszonyítási csoportot számunkra. A nyolcvanasok számára is.

\footnotetext{
${ }^{4}$ Bővebben ld.: Varga A. T.-Vercseg I. (2001) Közösségfejlesztés. Közösségfejlesztők Egyesülete, Budapest

${ }^{5}$ Giddens, A. (2000) Szociológia. Osiris, Budapest, p661

${ }^{6}$ Vercseg Ilona (1993) Közösség. Eszme és valóság. Közösségfejlesztők Egyesülete, Budapest

- letölthető: http://www.kka.hu/_Kozossegi_Adattar/Azadatt.nsf/cb64d6a7ffc532248525670c0080efa5/

7a5b2b352c0caf4485256640006a09c3?OpenDocument - utolsó letöltés: 2010. 11. 28.

${ }^{7}$ Giddens, A. (2000) Szociológia. Osiris, Budapest, p705
} 


\section{XY és az átmenet}

A nemzedékek katalógusában érzékelhetően van némi zavar. Egyes csoportosítók a nyolcvanas évekre lezártnak tekintik az X generációt, és az Y-t emlegetik. Mások éppen fordítva. Ám Magyarországra vetítve figyelnünk kell arra, hogy mind az X, mind az Y generáció fogalma nyugati eredetü, vagyis a kapitalizmus és a web 2.0-s technikai forradalom szele által korábban meglegyintett társadalmak viszonyai között érvényes életkori kategorizálást jelent.

Az X-ok főbb „paraméterei” a nyugati szakemberek szerint, hogy 1960 és '80 évek között születtek, ők a jóléti, fogyasztói társadalmak gyermekei. A generáció számos szubkulturális csoport által tagolt, a főbb irányzatok: rock, grunge/alternatív rock, punk rock, heavy metal, hip-hop, gengszter rap, techno és egyéb elektronikus zenék. A nemzedék tagjainak életstílusa is hasonlóan széttartó, az öltönyös, karrierista juppik éppúgy beletartoznak, mint a farmeres-kockás inges szakadt fiatalok és a spirituális ébredésre vágyó new age-esek.

Az Y-ok az X-eket követő generációba tartoznak (a '90-es, 2000-es évekkel bezárólag), legfőbb jellemzőjük a digitális, elektronikus világban való jártasság, a legújabb kommunikációs csatornák használata. A közösségi oldalak legaktívabb használóit találjuk közöttük, nagy az információigényük, önkifejezési formaként is használják az internetet, csetelnek, blogolnak, lájkolnak.

Hazánkba a fogyasztói társadalom és az elektronikus világ egyaránt fáziskéséssel érkezett, emiatt a magyar nyolcvanas generáció az átmenet generációja: az évtized első fele az X-hez köthetö, a második inkább az Y-hoz.

A '80-'85 között születetteknek, ha halványan is, de még van némi benyomásuk a szocializmusról: ők egy felpuhult, omladozó rendszer gyermekei (egy részük még kisdobos is volt), akik bár egy korai életszakaszban találkoztak a nyugati technika olyan vívmányaival, mint a videó, az első Commodor 64-es számítógépek vagy a mobiltelefon, a gépek használata tanult folyamat és nem adottság volt az ő kisgyermekkorukban.

A '85 utániak nem emlékeznek a szocializmusra, az úttörő mozgalomnak nem voltak tagjai, és kisgyermekkoruktól kezdve természetes számukra a (digitális) technika világa, ők Magyarország első igazi szájbergyerekei.

Vagyis a nyolcvanas évtized szülötteinek két különböző generációja egymásra torlódott: bár csupán néhány év választja el őket, mégis jelentős különbségek figyelhetőek meg közöttük.

Tehát terminológiai szempontból a nyolcvanasok mindenképp átmenetet képeznek.

Átmenetiek azonban abban az értelemben is, hogy a közösségiség mint a szocializáció egyik kulcseleme gyökeresen eltérően jelentkezett az ő életükben, mint az 1980 előtt születettekében. (A '90-esek közösséghez való viszonya a '80-asokéval mutat rokonságot - hasonló társadalmi körülmények befolyásolták ezt a viszonyt: erős nyugati befolyás, kapitalista rendszer stb.)

\section{Mi állhat ennek a hátterében?}

A rendszerváltással megtörtént a felszabadulás a szocialista eszmék kizárólagossága alól. 
Ezáltal a nyolcvanas évek szülötteinek óvodás, kisiskolás korában megszűnt a kötelező, homogén ideológiai nevelés.

A kapitalista gazdasági-társadalmi átalakulással szétmállottak a korlátok, amelyek korábban gátat vetettek a nyugati hatások szabad beáramlásának: különösen az amerikai-angolszász kulturális befolyás erősödött föl viharos gyorsasággal. Jött a videó, a hangalámondásos akciófilmek, az MTV, az HBO kora, Popcorn magazint és BRAVO-t lapozgattak az iskolások a pad alatt, betörtek a kilencvenes évek nyugati eredetű zenei stílusai. A popkultúra hullámai kiváltképp a rendkívül fogékony életkorban lévő akkori gyerekeket, kamaszokat terítették be.

A szocializmus erőszakos kollektivizmusa után, amikor az élet minden szintjét átitatta a politika, „a köz”, az emberek „a magánba” vonultak vissza, megfigyelhetővé vált a kényszerközösségektől való idegenkedés.

Emellett - ahogy erre már föntebb utaltam - a nyolcvanasok szüleinek olyan megváltozott körülmények között kellett volna mielőbb adekvát mintát szolgáltatniuk, amelyek számukra is újak voltak, s így a szülői életstratégiák csak kisebb mértékben bizonyultak átvehetőnek. ${ }^{8}$

Ezek a hatások együttesen nagyfokú individualizációt eredményeztek, melyben az olyan értékek, mint a közösségiség vagy a társadalmi részvétel, háttérbe szorultak.

A nyolcvanasoknak a közösségiséghez való, a megelőző generációtól eltérő viszonyát egy összehasonlítással szeretném fölvázolni.

A nyolcvanasok szüleinek közösségiségét az úttörő mozgalom példáján keresztül szemléltetem, mert jól tetten érhetők benne a közösségi szocializáció korabeli jellemzői. ${ }^{9}$

A szülők gyermek- és fiatalkorában a homogén, kötelező ideológiai nevelés érvényesült - egységesen, minden magyar fiatalra kiterjedően. Az úttörő mozgalom - bár számos pozitív vonással rendelkezett - alapvetően kényszerközösség volt, gyakorlatilag csekély tere volt a mozgalomtól való távolmaradásnak. Ez a kényszerközösség ráadásul egy egységes, felülről kialakított struktúrával bírt (ld. őrs, raj stb.!), amelyre a tagoknak nem volt befolyásuk. A mozgalom a kollektív cselekvést ösztönözte: egy-egy strukturális egység tagjainak (pl. őrsnek) együttesen, gyakran előre megadott szempontok szerint kellett feladatokat végrehajtania. Jellemző volt a kontroll, az uniformizáltság, ami a külsőségekben is megnyilvánult: a kisdobosoknak kék, az úttörőknek piros kendő dukált.

A rendszer a határokon túli, fóként a nyugati kulturális hatásokat igyekezett visszafogni.

Mindezek a folyamatok négy olyan dologgal „ajándékozták meg” a szülői generációt, amely akarva-akaratlanul is nagy kohéziós erőt hozott létre tagjai közöttük: 1. az uniformizáltságnak köszönhetően közel azonos (de mindenképpen a nyolcvanasokénál kevésbé széttöredezett) vonatkoztatási keretek alakultak ki körülöttük; 2 . a kontroll révén a rendszer implicit módon felkínált egy általános lázadásélményt az akkori fiataloknak

\footnotetext{
${ }^{8}$ Jó példa erre R., 1984-es lány interjúalany, aki említette, hogy amikor édesanyját kérdezte arról, hogy hogyan kell majd viselkednie az állásinterjú alatt, azt a választ kapta, hogy a szülője nagyon sajnálja, de nem tud tanácsot adni, mert ilyen szituációban még sosem volt, és gyakorlatilag az egész életét egy munkahelyen dolgozta végig.

${ }^{9}$ Természetesen nem azt állítom, hogy a szülők generációját kizárólag a szervezett, a nyolcvanasokét pedig kizárólag a spontán szubkulturális közösségiség jellemezte, csupán arányeltolodásról van szó, mely befolyásolta a két generáció közösséghez való viszonyát.
} 
- tapinthatóbb volt, hogy kiket lehet utálni (s tudjuk, a közös ellenségképzés jelentős összekovácsoló potenciállal bír); 3. a kényszerközösségeknek „hála”, valamilyen közösséghez mindenki tartozott, valamilyen közösségi élményt mindenki szerzett; 4. a rendkívül korlátozottan érvényesülő nyugati hatások miatt fennmaradhatott egy szűkebb, kiismerhetőbb hazai kulturális piac, ami a fiatalok számára nagy jelentőséggel bír: mindenki nagyjából ugyanazokat a zenészeket, együtteseket ismerte, ugyanazokat a számokat dúdolta, de legalábbis tudtak egymásról a korabeli popkultúra szereplői és befogadói. A virtuális világ hiánya miatt pedig a hagyományosabb kapcsolattartási formák primátusa volt megfigyelhető: ha a fiatal beszélgetni akart a barátjával, nem e-mailt írt, nem csetelt, hanem találkoztak.

Ilyen körülmények között tág tér nyílt az átfogó generációs élmények számára (például az olyan magánjellegűekre, mint az Ifipark-fellépések vagy olyan közéletiekre, mint később '89 etc.), amelyek szintén erősebbé teszik a kapcsolatot egy-egy nemzedék tagjai között.

Ezzel szemben a nyolcvanasok nemzedéke, a gyerekeik esetében mindennek az ellenkezője volt megfigyelhető. Ők már nem részesültek kötelező ideológiai nevelésben (ld. föntebb!), a laissez-faire elve alapján választani jóformán bármit lehetett, s hosszú idő után most először(!) lehetett semmit sem választani is. A sokszínűség, az egyéniség hangsúlyozása vált általánossá, az „én” került előtérbe a „mi”-vel szemben. A közösségi cselekvés iránti igény és bizalom mélyrepülésbe kezdett. Megszűnt a kézzelfogható ellenségkép, az új generációnak a lázadás szenzitív periódusában a politikával nem volt dolga, az a szülők, az idősebbek ügyévé vált, akik pedig egyébként nem tudtak általános érvényủ mintát nyújtani a gyerekeiknek. A fiatalok elfordultak „a köztől”, tért hódított az apolitikus attitủd. ${ }^{10}$ Visszaszorultak a kényszerközösségek, beszivárogtak a technikai újdonságok, a nyugati hatások voltaképpen gát nélkül ömlöttek erre a korosztályra, s ezernyi szubkultúrára tördelték szét. Tagjai - intézményesült ellenségkép híján - a többiek szubkulturális közösségétől próbálták élesen elhatárolni magukat (rockerek-rapperek-diszkósok stb.). Ezek a szubkulturális közösségek „belső vezérlésűek”, a belülről kialakuló spontán, informális struktúra jellemzi őket. A popkultúra hazai szereplői zömmel egy-egy külföldi stílusirányzatot lovagoltak meg (ld. a korabeli „tinisajtót”: BRAVO, Popcorn, IM, a tévében az MTV, a VIVA, az MCM stb.).

Ezek a folyamatok csökkentették a generációs élmények terét, átalakították a közösség fogalmához való viszonyt.

E jelenségek tükröződnek az interjúalanyaim válaszaiban is, akiket többek között a következőkről kérdeztem ${ }^{11}$ :

- Hogyan foglalnád össze a közösség fogalmát a saját tapasztalataid alapján? „Belülröl szervezödik valamely közös elv, cselekvés, érdek [...] motivációja révén." (R., 1984-ben született lány)

\footnotetext{
${ }^{10} \mathrm{~J}$ Ld: Ifjúság2008. Gyorsjelentés. - letölthető: http://www.szmi.hu/images/dok/ifjkutatas/ifjusag2008.pdf - utolsó letöltés: 2010. 11. 28.

${ }^{11}$ Kiemelések tőlem.
} 
„Azok a közegek, ahhonnan szivesen lestem el világnézettel, életmóddal kapcsolatos gondolatokat, vagy ha már volt kialakult véleményem valamiröl, szivesen osztottam meg azokat. Mindezt nyílván azért, mert az ottani emberek véleményére sokat adtam. A valahova tartozás valahogy sosem volt fó szempont, inkább az egyes emberek érdekeltek. Szóval a közösség fogalmát csak nagyon tágan tudom értelmezni, ahol talán csak egy eszme, vallás, vagy zenei stilus köti össze az amúgy egymásnak ismeretlen embereket. Pl. egy Junkies-koncert a Pecsában, ahol mindenki jófej a másikkal." (M., 1987-ben született lány)

\section{- Mit tartasz a '80-as korosztály generációs élményének?}

„Amikor meghalt Antall József [a halálhir miatt megszakitották a Kacsamesék vetitését 1993-ban]. [...] Az iskolatej és a köpeny annak számit? (S., 1984-ben született lány)

„Csupa negativ dolog jut hirtelen eszembe. Az elsö ezek között az elidegenedés, az elmagányosodás... Gáz..." (R., 1984-ben született lány)

"Nem tudom, talán a számitógépet. Mindig ahhoz mentünk, akinél lehetett játszani." (K., 1980-ban született fiú)

„Mi vagyunk az igazi átmenet, amit inkább a szüleink éltek meg igy, mint mi. A szüleinktöl sokat hallottunk a rendszerváltás elötti idökröl - hogy milyen jó volt, vagy milyen rossz volt, de nekünk most sokkal jobb, vagy rosszabb lesz -, szóval mindenképpen más. Ebböl viszont én személy szerint semmit nem éreztem, mert amikor kezdtem nyiladozni, akkor már gyakorlatilag az volt, ami most van. Nekem az a normális, hogy szabadon lehet utazni, hogy bármilyen zenét lehet hallgatni, a mozikban az összes film elérhetö. Emellett sokkal nagyobb szerepe van az egyénnek, mint azelött. Pl. akkor voltak az Abbások, meg voltak a Boney M-esek és valahogy sokkal komolyabban vették az ilyen fajta összetartozást és ellentétet, mint késöbb. Nálunk az ellentét talán megmaradt (például skinhead vs. punk - azok csúnyák voltak, de mostanra nem nagyon van ilyen szerintem), de bejött ez a nagy >>egyedinek lenniség<<”. (M., 1987-ben született lány)

- Tartoztál-e - $s$ ha igen, milyen - közösségekbe? (Kórus, rockerek, diszkósok etc.) Melyik volt meghatározó a számodra és miért?

„Hát, jártam kórusba, de utáltam, mert nekem túl kötött volt az egész. Ott semmilyen közösségi érzésem nem volt. Alapvetöen a rocker vonalon mozogtam, leginkább a zene miatt, megpróbáltam hippi is lenni (nyilván ehhez nem voltak társaim, ami nem volt gond, de igy persze nem mondható közösségi élménynek, csak mindíg nagyon tetszettek az eszméik, azok a zenék, amiket hallgattak, meg a ruháik) Igazából ezek mind meghatározóak voltak, az alapot adták, amire lehetett - meg még mindíg lehet - épitkezni. Mindegyikböl csak annyit tettem magamévá, amennyire szükségem volt, vagy amik tetszettek belölük. Maradéktalanul soha nem értettem egyet semmilyen közösség ideológiájával." (M., 1987-ben született lány)

- Van-e valamilyen nyilvános véleményformálással kapcsolatos közösségélményed? (Pl. tüntetés, felszólalás stb.)

„Hát, nem igazán. Az ilyenektöl ugyan nem tiltottak, de mindíg óva intettek a szüleim és amellett, hogy ez belémnevelödött, nem is nagyon volt rá igényem. Mondjuk egy talán van, ha ideillik: 16 évesen egy barátnömmel részt vettem az uniós csatlakozáson a Hösök terén. 
Oda, gondolom csak olyanok mentek, akik jó dolognak tartották ezt, igy tehát ez is lehetett egy nyilvános véleményformálás." (M., 1987-ben született lány)

A válaszok alapján - visszautalva a vizsgálatom szerény lehetőségeire - általános kijelentések megfogalmazására nem vállalkozok. Ám a témámat illetően mégis kirajzolódik néhány figyelemreméltó jelenség az interjúalanyaim esetében: a közösséghez füződő viszony ambivalens. A megkérdezettek mindegyike valamilyen minőségi többletet, érzelmi kötődést sejt a közösség fogalmába. A közösséghez tartozást belülről motiváltnak tartják. Közösségi élményeik szubkulturális gyökerűek, négyből hárman a zenéhez kötik ezeket. A formalizált közösségektől elzárkóznak.

Számomra a legérdekesebbek a korosztályuk generációs élményeire vonatkozó válaszaik voltak. Két-két hasonló válasz született: a) az egyikük a negatív dolgokat, a magányt, az elidegenedést tekinti a nyolcvanasok generációs élményének. A másikuk az egyediséget emelte ki. b) A másik két megkérdezett válaszában technikai eszközökre utalt (a tévére és a számítógépre). Egyikük hozzá is füzte, hogy milyen furcsa számára, hogy a tévé vagy a számítógép segítségével úgy valósulhatnak meg közösségi élmények, hogy közben az ember fizikailag akár egyedül is lehet. Mégis, maga az élmény képes igazi lenni. A többieket meg majd odaképzeljük.

\section{Zárszó helyett}

A kereteim szűkösek voltak, mégis jó lenne tovább gondolkodni, hiszen számos kérdés merült fel bennem a téma kapcsán - $s$ bízom benne, hogy az olvasóban is. Úgy vélem, hogy egy olyan örökké aktuális és alapvető fontosságú üggyel, mint amilyen a jelenlegi vagy a mindenkori fiatalok integrációja a társadalomba az olyan közösségi értékek, készségek elsajátításával, mint az együttműködési képesség, tolerancia, szolidaritás, asszertivitás, párbeszédkultúra vagy a részvétel; felelőtlenség és luxus nem foglalkozni. Az idősebb nemzedéknek azért, hogy partnerévé, szövetségesévé válhasson a fiatalabb, a fiatalnak pedig azért, mert egyes emberek halmazaként nem, csupán közösségként képes szót kérni az őt övező generációk erdejében.

\section{Irodalom}

Coupland, D. (2007) X generáció. Európa, Budapest

Furlong, A.-Stalder, B.-Azzopardi, A. (2003) Sebezhető ifjúság. Belvedere Meridionale, Szeged Giddens, A. (2000) Szociológia. Osiris, Budapest

Gábor K.-Jancsák Cs. [szerk.] (2006) Iffúságszociológia. Belvedere Meridionale, Szeged

Kátai G. (2006) Gondolatok az ifjúságpolitikáról és eszközeiröl. Belvedere Meridionale, Szeged László J. (2009) A háló továbbszövése. Az ifjúsági irodák haszna különös tekintettel a reziliencia alakulására. In: Szabó Fanni [szerk.] (2009) Társadalmi tanulmányok. ELTE TáTK HÖK, Budapest, p145-178.

Müller, C. W. (1992) Hogyan vált a segitségnyújtás hivatássá? Hilscher Rezső Szociálpolitikai Egyesület, Budapest

Nagy G. [szerk.] (2008) Ifjúságügy. Ifjúsági szakmai, iffúsági munka. Új Mandátum Budapest Németh A. [szerk.] (2007) Serdülökorú fiatalok egészsége és életmódja. OGYEI, Budapest

Szabó A.-Bauer B. (2009) Ifúuság2008. Gyorsjelentés. Szociálpolitikai és Munkaügyi Intézet, Budapest - letölthető: http://www.szmi.hu/images/dok/ifjkutatas/ifjusag2008.pdf

Slézia G. [szerk.] (2001) Fiatalok az utcán. Budapesti Müvelődési Központ, Budapest

Varga A. T.-Vercseg I. (2001) Közösségfejlesztés. Közösségfejlesztők Egyesülete, Budapest

Vercseg Ilona (1993) Közösség. Eszme és valóság. Közösségfejlesztők Egyesülete, Budapest-letölthető: http://www.kka.hu/_Kozossegi_Adattar/Azadatt.nsf/cb64d6a7ffc532248525670c0080efa5/ 7a5b2b352c0caf4485256640006a09c3?OpenDocument 


\section{Stalzer Tamara:}

\section{A családmodell átalakulásának hatása a párkapcsolatokra}

Hipotézisemet úgy fogalmazhatnám meg, hogy a '80-as generáció tagjai nehezebben alakítanak ki jól mủködő párkapcsolatokat, mivel a válások egyre gyakoribbá válásával, az ilyen családokban felnövők előtt nincs követendő példa.

Kutatásomat szeretném bemutatni a témához kapcsolódó szociológiai, pszichológiai és demográfiai tanulmányok és a felvett interjúk elemzésével. Az esszé első felében kitérek a családmodell átalakulásának szociológiai hátterére, hogyan hatottak a társadalom egészét érintő változások a párkapcsolatok alakulására. Majd a gyermekek családon belüli szocializációjának fontosságára szeretném felhívni a figyelmet pszichológiai megközelítések által. Ezután az interjúk elemzése következik, majd az összegzés és a hipotézis igazolása vagy elvetése.

\section{A családmodell átalakulása szociológiai szempontok}

A párkapcsolatok átalakulása Magyarországon már az 1990-es évek előtt megkezdődött és egyre jobban követi a nyugati trendeket. A család fogalma, szerkezete, jelentéstartama is megváltozott, köszönhetően életmódunkban, világunkban bekövetkező gyökeres változásoknak. A családok átalakulásának indikátoraként a házasságkötések és a válások számának változását vizsgáljuk, mivel a családok definiálására általában az intézményesített keretek közt zajló tevékenységek szolgálnak megoldásként.

A rendszerváltás óta a válási hajlandóság nagymértékben megerősödött, míg a házasság kötések száma visszaesett. Ezt nagyon jól mutatja a teljes válási arányszám, mely 2000ben még a 40\%-os szinten állt, de mára már minden második megkötött házasságra egy válás jut.

De szembetűnőbb a változás, ha a '80as évek demográfiai eredményei mellé állítjuk a 2004-ben felvett adatokat:

1980: 80.000 házasság, 1000 házasságra jutott 346 válás

2004: 43.800 házasság, 1000 házasságra jutott 562 válás

Láthatjuk, hogy a megkötött házasságok száma majdnem felére csökkent, míg az 1000házasságra jutó válások aránya megnőtt.

A válás, mint problémamegoldási forma, terjedésének okaként nagyon sok befolyásoló tényezőt határozhatunk meg. Talán a legfontosabb tényező, hogy növekedett az átlagos élettartam, ami magával hordozza azt is, hogy sokkal hosszabb együttélés vár a házasulandó fiatalokra, mint korábban. Ez ma átlagosan 40 év, ez alatt pedig nyilvánvalóan kétszer olyan magas a válás előfordulásának valószínűsége, mint majd egy évszázada, mikor ez 
még csak 20 év volt. Ennek a folyamatnak is köszönhető, hogy kitolódott a házasulandók életkora. A nők esetében például az 1990-es 21,8 évhez képest 2004-ben már 26,5 volt. Az életciklusok időtartama is módosult, így sokkal hosszabb az az idő, melyet a szülők a gyermekeik önállósodása után együtt töltenek. (Spéder,2005)

A házasodási életkor nem csak az átlagosan várható élettartam emelkedése miatt tolódott ki, nagy szerepet játszik benne a nők emancipációja is. A felsőoktatási képzésbe történő egyre nagyobb arányú belépésük és a munkaerőpiacon betöltött szerepük erősödése mind befolyásolja a nők gyermekvállalási és családalapítási szokásait. Azzal, hogy egy nő már saját keresetéből is fenn tudja tartani magát és gyermekét, szabadabb döntéshozásra ad lehetőséget abban, hogy elköteleződik-e egy férfi mellett, esetleg kilép-e egy rossz kapcsolatból? A családmodell átalakulásában a korszerü fogamzásgátlási módszerek is szerepet játszottak. Csökkent a termékenység, megváltoztak a nemi magatartás konzervatív normái és attitűdjei, melyek megint csak szabadabb döntési lehetőséget adtak a nők kezébe.

A vallási normák és a keresztény erkölcs gyöngülése is hatott a válások terjedésére, mivel sem az egyház, sem a közerkölcs nem ítéli meg már olyan erőteljesen a válást. A házasság felbontása a konfliktusok megoldásának legitim módjává vált. Meg kell említenünk még a keresztény erkölcs meggyengüléséhez kapcsolódva, a fiatalok esetében jelentkező negatív hatásokat, melyek hátráltató tényezők lehetnek a hosszú távú kapcsolatok kialakításánál. A mi generációnk tagjaihoz már jóval kisebb mértékben ért el az ilyen irányú nevelés, így egyre szükülő teret kapott a ráépülő normák bevésődése. Elterjedt viszont az individualista értékfelfogás, mely amellett, hogy sokkal szabadabb teret enged az ego megnyilvánulásainak és az önmegvalósításnak, viszont nem kedvez a hosszú távú kapcsolatok kiépítésének, melyeknek elengedhetetlen feltétele például a kompromisszum készség vagy sokszor a saját igényeinkről való lemondás. Ezért alakulhatott ki az a tendencia, hogy növekedett a párkapcsolatok minősége iránti igény, az emberek sokkal nagyobb teret követelnek saját önmegvalósító törekvéseiknek és igényeik kielégítésének, viszont kevésbé toleránsak a másikkal és többet is várnak el társuktól, mint régen. (Utasi,2000)

A nők helyzetének megváltozása mellett nem hagyhatjuk figyelmen kívül az apa szerepének megváltozását sem. A férfi helyzete a családban meggyengült, mivel már a nők is rendelkeznek kereseti lehetőséggel, emellett általában az anya látja el a gyermek nevelését is. A magyar válóperek során a gyerekek több mint $90 \%$-a az anyához kerül és vele is él ezután. Sajnos a kutatások során arra nem derült fény, hogy a válás után milyen marad az apa-gyerek kapcsolat és hogy mennyi időt töltenek együtt, de az biztos, hogy kisebb hatást tud gyakorolni a gyermek személyiségfejlődésére, nevelésére.

A családmodell átalakulásának okaként megjelölhetjük még az életszínvonal emelkedését, és az állam belépését a szociális szférába, mely miatt az idősebb generáció tagjai nem élnek együtt a családdal, így a tradicionális nagycsalád modell felbomlott.

A válások és a családmodell átalakulásának okai mellett fontosabb e változások hatásaival foglalkozni. Az új helyzetek, jelenségek és életszakaszok megjelenése, majd mindennapivá válása magával hordozza az erre reagáló társas viselkedési formák megjelenését is. A szociológiában a család funkcióit öt fő pontban határozzák meg. Első a termelés, második a fogyasztás, harmadik a népesség reprodukciója, negyedik a gyerekek szocializációja, ötödik pedig a felnőttek pszichés védelme. A termelés a modern társadalomban teljesen levált 
a családról, a munkahelyek elkülönülésével, viszont a fogyasztás még mindig a családon belül zajlik.(Andorka,1997) Fontosabb funkció számunkra azonban a gyerekek szocializációja, melyet semmilyen intézmény nem képes helyettesíteni a családon kívül, így a család felbomlása, meggyengülése ezen a téren hordozza a legnagyobb veszélyeket. Persze a felnőttek pszichés védelmének funkcióját se hagyhatjuk figyelmen kívül, se ennek elvesztését, például olyan esetekben, ahol a házasság felbomlása után az egyik fél egyedül marad.

Sokan a családmodell válságának jeleinek látják, hogy megnőtt a párkapcsolati formák száma, elterjedtebb lett a házasság nélküli együttélés, a szingliség, változatosabb családtípusok alakulnak ki. Ugyanakkor ezek felfoghatóak a család változó és tűrőképességének indikátoraiként is. Például Magyarországon kutatásokkal igazolták, hogy míg sokan támogatják az együttélést, mint párkapcsolati formát, végső célnak az emberek zöme még mindig a házasságot tekinti.

A szülők válásán kívül meg kell vizsgálnunk még egyéb hatásokat is, melyek hátráltató tényezők lehetnek egy párkapcsolat kialakításában:

\section{Média hatásai:}

Ha tudat alatt is, de erős szocializációs befolyás alatt áll a mai ember a média, a tömegkommunikáció által. De véleményem szerint a reklámok és a televízió műsorai nem adnak egészséges képet egy kapcsolatról. Nem mutatnak be harmonikusan müködő családokat, követhető magatartásformákat. A televízió műsorok többnyire nem olyan értékeket közvetítenek, amelyek egy stabil kapcsolat fenntartásához elengedhetetlenek.

\section{Posztadoleszcencia:}

A fiatal felnőttek egyre hosszabb ideig maradnak szüleikkel egy háztartásban, a felsőfokú tanulmányok elvégzésének egyre hosszabb ideje és a munkakezdés nehézségei miatt. A financiális egzisztencia megteremtése fö szempont a családalapításnál, ennek időpontja emiatt is egyre kitolódik.

\section{A társas terek beszükülése, eltünése, átalakulása:}

Az interjúalanyok közül sokan említették ezt a problémát a kapcsolatok kialakításának nehézségének fó okaként. Az oktatási intézmények szocializációs terein kívül egyre kevesebb az olyan hely, tér melyben a fiatalok szociális készségei fejlődhetnének, megtapasztalhatnák a közösséghez való tartozást érzését, új kapcsolatokat alakíthatnának ki.

\section{Pszichológiai háttér}

A gyermek szempontjából a család egyik legfontosabb feladata a szocializáció. A szocializáció a társadalomba való beilleszkedés folyamata, amelynek során az egyén megtanulja megismerni önmagát és környezetét, elsajátítja az együttélés szabályait, a lehetséges és elvárt viselkedésmódokat. Ezen keresztül tanulja meg a környező társadalom kultúráját, normáit, értékeit, a világban betöltendő státuszait, szerepeit. Gyermekkorban a család az első és legfontosabb szocializáló közeg, de később hatással van az egyénre a nagyobb társadalmi környezete, a kortárscsoportok és mai világunkban a média. Témakörünkhöz 
kapcsolódva a családon belüli szocializáció során alakulnak ki a gyerekben az intim kapcsolatok működésének és a családban való szerepének mintái. Itt kapunk mintát különböző szerep kapcsolatokra, tanuljuk meg a státuszok hierarchiáját, az emberi kapcsolatok kölcsönösségen alapuló működését és itt alakulnak ki a későbbi csoport hovatartozás motivációi. Fiatalkorban a család keretein belül alakul ki alapszemélyiségünk, mely persze nem zárja ki a későbbi személyiségfejlődést, de irányt szab neki. (Cole,2006)

A család egészsége, a felnövő gyerek lelki egészségének döntő tényezője is. Stabil, biztonságot adó családi légkör nélkül a gyerek személyiségfejlődésében komoly törések, zavarok keletkezhetnek, melyek kihathatnak egész életére.

Ha a gyermek egyszülős családban nő fel, nem tudja elsajátítani későbbi szerepét egy jól működő kétszülős családban. Több pszichológus a szülői család összetételét tekinti meghatározónak a saját családalapítási sikerét vagy sikertelenségét eldöntő készségek és képességek kifejlődésében.

A szülők válása nem csak a szocializációs sémák elsajátításában okozhat torzulásokat. Az egyik szülő távozása a családból, magával hordoz egyfajta veszteségérzetet, melyet a család minden tagja megél. Abban az esetben, ha ez nincs jól kezelve, komoly pszichózisokat okozhat. Például a családon belüli problémákra vezethető vissza a fiatalkori devianciák kialakulásának nagy százaléka. Nem is beszélve arról, hogy az egyedül maradó szülő is sokkal sérülékenyebb lesz pszichésen, köszönhetően a családi kapcsolatok nyújtotta védelem elveszésének, gyengülésének. Persze egy kapcsolat megromlása, válás nélkül, is hasonló folyamatokat indíthat el az emberben.

Meg kell említenünk a válás utáni élethelyzetek hatásait is az egyénre. Az életszínvonal, esetleg a lakókörnyezet megváltozása is negatívan befolyásolhatja a lelki állapotokat, tekintve, hogy alapvető, életünket nap mint nap alakító tényezők változnak.

Ezek is hátráltató tényezőként hathatnak egy egészséges kapcsolat kiépítésénél.

\section{Interjúk elemzése}

Az interjúkat 80 -as években született egyetemista, vagy egyetemet végezett személyekkel készítettem. Az alanyok egyike sem él se élettársi, se házastársi kapcsolatban. Ez persze magával hordozza azt a tényt, hogy az népesség csak kis szeletére korlátozódik ez a felmérés. Tény, az is, hogy felsőoktatásban eltöltött évek nagymértékben kitolják a házasodási életkort, ezt figyelembe kell vennünk, mikor az interjúkat elemezzük. Az interjúalanyok közt megosztottan volt elvált és együtt élő szülői hátterű. Az elvált családoknál a fiatalok váláskor betöltött életkora sem egyezik. Az életkor meghatározó tényező lehet abban a szempontban, hogy a gyermek milyen szocializációs fázisban tart, mennyire tud adaptálódni a kialakult új helyzethez. A nem elvált szülők gyermekei közül is sokan számoltak be arról, hogy nem boldog párkapcsolatban élnek szüleik, ami megint csak hátráltató tényező lehet a kapcsolatok minta követése kapcsán. Ez pedig arra utal, hogy még a hivatalos válás hiánya sem biztosítja a követendő példát. (ld. Pszichológiai háttér)

Ez egy személyes téma, így a nyílt kérdések lehetőséget biztosítanak a személyes meggyőződés kifejtésére, illetve az interjúk során a spontán reakciókat is meg lehet figyelni, ami nagyon előnyös lehet egy ilyen sokak számára „,kényes” területen ezért választottam 
a kérdőívezés helyett az interjúzást, mint módszertani eszközt. Ennek viszont hátránya, hogy kisebb mintával dolgoztam, 20 embert hallgattam meg.

A kérdéseket több nagyobb témakör köré próbáltam csoportosítani, ezek:

- a családi háttér és a társas behatások

- egyéb meghatározó tényezők- médiabefolyás, mobilitás

- egy előző párkapcsolat leírása

- jövőkép- hogy látja magát 5, 10, 20 év múlva

- hogyan látja a témát, a párkapcsolatokat, házasságot, ezek nehézségei sajátmaga számára

Az első kérdéskörben máris felállt egy elég erőteljes általános értékrend a fiatalok válaszaiban, miszerint az egészséges, életen át tartó házasságot tekintik követendő példának. Sokan még a két szülős családokban élők közül is nagyszüleik párkapcsolatát tartják elérendő célnak, mivel az harmonikusabbnak, kiegyensúlyozottabbnak tetszik. Persze itt nem hagyható figyelmen kívül az a tény, hogy a nagyszüleik kapcsolatával nem szembesülnek minden nap és hogy nem részesei annak kezdetektől fogva. Az ismerősök, rokonok befolyásoló hatásai kevésbé érvényesülnek. Ez leginkább a testvérekre korlátozódik. A tömegkommunikáció és a média behatásait sem mondták meghatározó tényezőnek a párkapcsolati minták követésében. Itt meg kell említeni, hogy ezek inkább tudatalatti befolyással bírnak, tehát szerepüket így sem hagyhatjuk figyelmen kívül. Az intelligencia szerepét sem vethetjük el a médiafogyasztásban, valószínü, hogy az alacsonyabb intelligenciájú emberekre nagyobb befolyást gyakorolhat a tömegmédia. A mobilitás kérdéskörénél a felsőfokú képzés miatti helyváltoztatás bizonyult módosító tényezőnek. Ez általában pozitív hatással bírt a kapcsolatok kialakításánál, mivel emiatt a ,kétlakiság” miatt látókörük szélesedett, több embert ismerhettek meg. Az előző kapcsolatok leírásánál a megkérdezettek általában első párkapcsolatukat írták le. A megismerkedésben, kezdeményezésben még mindig tradicionálisnak mondható a férfiak szerepe és ezek a kapcsolatok hónapokig, évekig is eltartottak. Jövőképük leírása is alapvetően egységesnek bizonyult, itt is megfigyelhetjük a házasodási életkor kitolódását. A legtöbbjük ezt a 10 év múlva kategóriába sorolta, ez 30 éven felüli életkort jelent, viszont már 5 év múlva szeretnék megismerni jövendőbeli társukat. Említették a házasság nélküli együttélést lehetséges alternatívaként, de ez Magyarországon inkább a házasságot megelőző formulaként elfogadott. Egy nagyon kis százalék viszont a válás gondolatától se tudott elvonatkoztatni jövőképében.

A párkapcsolatok kialakításában nehézséget a társas helyek beszűkülésében láttak, például, hogy nincs lehetőségük új embereket megismerni. Sokan említették viszont itt a baráti társaságokon keresztüli ismerkedést, tehát feltételezhetünk egy laza hálózati kapcsolatrendszert, ami valamilyen szinten pótolja a fóbb szociális hálókat. A társas helyek beszűkülése mellett említettek még több individuális, személyhez köthető jelenséget. Például, a megkérdezett nem elég bátor megszólítani a másikat, ha nem olyan közegben zajlik a megismerkedésük, ami számára kedvező, esetleg nem kap elég visszajelzést arról, hogy jó irányban halad-e a kezdeményezés folyamatában. A hosszútávú kapcsolatok kialakításánál, pedig két ember összeférhetetlenségét és a hosszú idő alatt felmerülő problémák megoldásaiban láttak nehézségeket. 


\section{Összegzés}

Minden általunk ismert társadalom alapja a család. Minden jel arra mutat, hogy ma ez az egység olyan változásokon megy keresztül, melyek kimenetelét nem tudjuk megjósolni. A kitolódó házasodási életkor, az együttélés, mint hosszútávú együttélési forma, elfogadottá válása, a válások számának növekedése, a csökkenő gyerekszám és a házasságkötések alacsony száma mind egy tendenciát követ, a tradicionális családmodell gyökeres átalakulását. Minden esetre a család szerepe az egyén életében koránt sem elhanyagolható. Olyan funkciókat tölt be, melyeket eddig semmilyen más általunk ismert szociális közegnek nem sikerül. A család felbomlása hosszú távú következményekkel jár az egyének életében és ennek a lehetséges pozitív hatásai, közel sem egyenlítik ki a felmerülő negatív hozadékokat.

Mint ahogy az interjúkból kiderült a 80-as generáció tagjai még hisznek a család fenntarthatóságában és saját családjuk megalapítását látják elérendő célnak. A kérdés az, hogy birkóznak meg a feladattal, ha nincs előttük egy élhető, megvalósítható példa, ha egyre kevesebb az esély kapcsolatok kialakítására, ha egyre kevesebb a motiváció?

Hipotézisünket egyrészt igazolni tudjuk, hiszen tudjuk milyen meghatározó példakövetés szempontjából az ép családi háttér. Viszont, hozzá kell tenni, hogy nem csak a példakövetés hiánya irányítja a változásokat. Láthattuk, hogy a társadalmi normák átalakulása, az életszínvonal emelkedése, a média térnyerése mind magával hordozza a családmodell, a párkapcsolatok átalakulását.

Összefoglalva az eddig leírtakat elmondható, változó világunk olyan kérdések megválaszolása elé állít minket, melyekre még nem sikerült megoldást találni. A mi generációnk feladata, hogy megtanulja kezelni a fenn álló helyzetet és kialakítson egy új élhető párkapcsolati és családformát.

\section{Irodalomjegyzék}

Andorka Rudolf (1997) A család, in: Bevezetés a szociológiába, Budapest, Osiris Kiadó 11.fejezet 351-357., 8.fejezet 272-282

Preglau, Max (2000) A kockázati társadalom (Ulrich Beck)- a társadalmi posztmodernizálás egyik esete? In: Morel et.al (szerk) Szociológiaelmélet, Osiris Kiadó, 286-291.

Cseh- Szombathy László (1973) A gyermekkori szocializáció jelentősége a házastársi és szülői szerepekre való felkészítésben, in: Családszociológiai problémák és módszerek, Bp, Gondolat 34-150.o

Somlai Péter (1986) A családi kapcsolatok társadalomtörténetének fö irányai, in: Konfliktus és megértés, Bp., Gondolat, 55-101.

Cseh-Szombathy László (2000) A házasság minősége, in: Elekes-Spéder (szerk) Törések és kötések, ARTT, 239-254

Utasi Ágnes (2000) Tradicionális család individuális értékpreferenciákkal, in: Spéder-Tóth (szerk) Emberi viszonyok, ARTT, 137-157.

Vaskovics László (2000) A társadalmi modernizáció és a munkamegosztás a partnerkapcsolatokban és a családban, in: Törések és kötések, 287-304.

Michael Cole, Sheila R. Cole (2006) Fejlödéslélektan, Osiris Kiadó, Budapest

Dr. Bagoly Emőke (1977) Családi szocializáció és személyiségzavarok, Nemzeti Tankönyv kiadó

Charles S. Carver, Michael F. Scheier (1998) Személyiségpszichológia, Osiris Kiadó, Budapest

Rita L. Atkinson - Hilgard - Edward E. Smith - Susan NolenHoeksema - Barbara L. Fredrickson - Geoffrey R. Loftus(2005) Pszichológia, Osiris Kiadó, Budapest

Anthony Giddens (2003) Szociológia, Osiris Kiadó, Budapest 


\section{Berecz Diána - Molnár Zsófia - Papp Gergely:}

\section{A motivációs levélen innen és túl}

A 1980-85 között született „kreatívos” fiatalok a munka világában

\section{A motivációs levélen innen...}

Mellékelt önéletrajzomból kitünik, hogy többéves szakmai tapasztalattal rendelkezem, ami a szakma iránti elkötelezettségemet szimbolizálja. Pályakezdöként már több munkaterületen is kipróbáltam magam és rájöttem - legszivesebben olyasmivel foglalkozok, amit igazán szeretek hobbiként is. Így kerültem bele ebbe a szakmába, amit már jó pár éve hivatásomnak vallok.

Mit keresek?

Egy olyan munkahelyet keresek, ami kreativ és nem foszt meg annak a lehetöségétöl, hogy használjam az eszem, ami nem "gyár” szagú, ahol lehet és kell ötletelni.

Egy olyan munkahelyet keresek, ahol felhasználhatom innovativ vénámat, ahol a kommunikációs képességeimet kihasználva, nem napi rutinfeladatot ellátva dolgozhatok egy adott, kitüzött cél elérése érdekében.

Egy olyan munkahelyet keresek, ahol szükség van a lendületemre, pozitiv szemléletemre, munkabirásomra. Ahol érzem, hogy a munkámnak és tudásomnak értéke van.

Egy olyan munkahelyet keresek, ahol jelen vannak a kihivások, ahol új lehetöségek feltárására törekedhetek. Ahol bövithetem jelenlegi tudásomat és fejleszthetem képességeimet.

A meghirdetett munkakör leírása igen közel áll az általam ideálisnak vélt feladatkörhöz, mivel igényli tapasztalataimat a csapatban való gondolkodás, az önállóság és a problémamegoldás terén.

Meggyözödésem, hogy a készségeim alapján értékes tagja lennék a csapatnak, kialakult kapcsolatrendszerem, ügyfélorientált meglátásaim, alkalmassá tesznek a közös munkára.

Egy személyes találkozás alkalmával, erröl meg is bizonyosodhatnak.

A fentiekben egy motivációs levelet olvashatunk, amelyben olyan hívószavakat találunk, amelyek a legtöbb általunk összegyűjtött önéletrajz mellé küldött kísérő levelében előfordulnak. A motivációs, vagy kísérő levél egyik fontos rendeltetése az, hogy meggyőzzük a munkaadót, hogy a meghirdetett pozícióra szakmai tapasztalatunk, képességeink, motivációink, tulajdonságaink alapján mi vagyunk a legalkalmasabbak. Mindezt úgy, hogy a munkaadói oldal szubjektív értelmezésére bízzuk, hogy mit ért az általunk felsorolt fogalmak alatt. Szolgáljon tehát a motivációs levél korunk munkavállalási stratégiájának jelképéül. Hamarosan kiderül, hogy miért.

A jelenség, amit be szeretnénk mutatni, egy adott szakmán belül dolgozó, az 19801985 között született, mai huszonéves fiatalok munkához való viszonya, ennek kihatása életvitelükre, annak szervezésére, jelenlegi motivációikra, ezzel kapcsolatos munkavállalási stratégiáikra és végezetül a jövőbeli terveikre.

Két fontos tényező miatt vált érdekessé ezen korosztály munkakultúrájának vizsgálata, 
amely véleményünk szerint eltér a szüleik generációjának munkához való viszonyulásától. Az egyik tényező a politikai és gazdasági rendszerváltás, a másik pedig a tömegkommunikáció elterjedése és a világ értelmezésének felgyorsulása. E két tényező közel egyidejü, együttes megjelenése megnehezíti ezeknek a fiataloknak a munka világába való integrációját, oly módon, hogy a korábbi generációk életpályája, egyes speciális pályákat leszámítva nem tekinthető példának.

Kérdőíves vizsgálatunk után kirajzolódtak szempontjaink, amelyek a „kreatív” szakmában dolgozó fiatalokhoz vezettek el. Három, Budapesten működő reklámügynökség közül választottuk ki azt a multinacionális reklámügynökséget, amelynek kreatív munkatársaival készült interjúkon keresztül mutatjuk be munkához füződő viszonyukat és életvitelüket. Véleményünk szerint egy korunkra nagyon is jellemző életstílus intézményesülése figyelhető meg náluk.

Az sem elhanyagolható szempont, hogy egy olyan közegről van szó, ahol 20-35 év közötti fiatalok a munkavállalók és sok esetben a vezetők is, ami pont a korábban említett korosztályt fedi le.

Az alábbiakban a motivációs levélből kiemelt hívószavak mentén mutatjuk be a megkérdezett fiatal „kreatívosok” munkakultúráját és ehhez kapcsolódó életvitelének általunk fontosnak ítélt részeit: a változáshoz való viszonyulást, a folyamatos tanuláshoz való hozzáállást, a karrierépítést, és a jövőképet igyekszünk bemutatni. Tehát a motivációs levelet többlettartalommal ruházzuk fel, amelyben nemcsak a fogalmak, de a megkérdezettek értelmezései is megjelennek.

\section{Kreativitás}

A „kreatív” az az ember, aki egy ügynökségen belül egy új világot épít fel a reklámozott termék köré, ezáltal megkreál egy márkát. Azért dolgozik, hogy mindennap legyen egy lehengerlö ötlete.

A szövegírók feladatai nem merülnek ki csak az ötletek gyártásában, az agyaláson túl segítik a grafikai munkát, ehhez képeket és inspirációt kutatnak az interneten, a tenderért felelős vezető gondolatait dolgozzák ki, asszisztálnak a forgatásokon, fotózásokon, szlogeneket írnak, és mindezeket prezentálják a vezetők valamint a megrendelők felé. $\mathrm{Az}$ art direktor a vizuális szakember, a grafikai munkában vesz részt, de elsősorban koordinálja azt.

A kreatív hozzáállás a folyamatosan változó munkakörökhöz interjúalanyaink életében kulcsfontosságú, életvitelüket alapvetően meghatározza.

„Nem tudom neked definiálni, hogy mi az, amivel foglalkozom, mi a hivatásom, viszont az már régi ötletem, hogy csinálok, tervezek magamnak egy névjegykártyát (...) ezen csak egy dolog állna: Gergő, kreatív, ez mindent elárul rólam. Olyan vagyok, mint egy svájci bicska, sok mindenre vagyok képes, sok mindenre használhatnak, csak ki kell nyitni ahhoz a megfelelő részt bennem. (...) A lényeg a kreativitás, hogy alkothassak, hogy értelme, produktuma legyen a munkámnak." (Gergö)

A kreatív hozzáállás nemcsak a munkájukhoz szükséges attitüd, hanem egyik elsőrendü motivációjuk mindennapjaik során.

„Ez egy szórakoztató meló, gondolkodni kell, ülök, beszélgetek másokkal és ez a mun- 
kám, itt tényleg szórakozni kell, vidámnak kell lenni, viccesnek kell lenni, asszociáció kell (...) képzeletem van, fantáziám van, és ezeket adom el tulajdonképpen.” (Eszter)

„Nagyon sok ötletem van és mindegyiket meg akarom valósítani, és meg is szoktam őket, de nem vagyok az az ötletelő, aki végül nem csinál semmit, csak hát kell hozzá pénz, lehetőség, ami nem mindig van meg." (Gergő)

„Fontos, hogy mit csinálsz,... hogy itt vicces dolgokat lehet csinálni, (...) úgy értem, hogy vicceset, hogy amin gondolkodni kell, aztán eljutsz valahova, amit mások is jónak tartanak." (Ádám)

A kreativitáshoz szorosan kapcsolódva megjelenik a kíváncsiság, az új, a szokatlan iránti igényük, amit nyitottságként értelmeznek. Ez nem is véletlen, mivel a váratlan élethelyzetekhez, amit a szakma állít mindannyiuk elé, a folyamatosan felmerülő kihívásokra tudniuk kell nyitottan és az újonnan megjelenő szituációra érzékenyen válaszolni.

\section{Nyitottság, új kihívások keresése}

Ezt a nyitottságot sokat hangoztatják, s föként pozitív töltettel rendelkező személyiségjegyként értékelik szakmájukban. Az újra való nyitottsággal szorosan összefüggő tényező az állandó változás igénye, az új ingerek keresése, a régiek lecserélése.

„Van egy ilyen, furcsa nézet vagy elvárás, hogy az az ember, akinek nincsenek nagyobb elvárásai a környezeti változásokkal kapcsolatban, nincsenek elvárásai az új ingerek iránt, az nem fog tudni kreatívként dolgozni, az unalmas. Ugyanabban a közegben nem lehet folyamatosan, sokáig kreatív munkát végezni. És ez valamennyire igaz. Nekem az volt a szerencsém, hogy az 5 és fél év alatt, körülöttem mindig változott a környezet, gyakorlatilag másfél év volt a leghosszabb, amíg együtt voltam egy fönökömmel, meg amíg egy szakmai elvárásnak feleltem meg, utána jött valaki más és más szempontokat nézett, tehát, vagy egy kicsit másképp gondolkozott a munkáról, utána jött megint más és megint más dolgokat lehetett tőle tanulni (...) És egyébként nagyon nagy volt a fluktuáció a cégnél is a vezetőség szintjén is, és nem az lett, hogy mellettem kicserélték az embereket, hanem gyakorlatilag új vezetőket kaptam, egészen más hozzáállásuk volt, egészen máshogy kellett dolgozni, pozitív irányba, és más dolgokat lehetett tőlük tanulni." (Szilárd)

Így a nyitottság nemcsak az új feladatkör megoldásáról szól, hanem a megkérdezettek tapasztalatszerzésükben is szeretnének mindig új pozícióban megmérettetni, mindig új közegben sajátítani el újabb gyakorlati tudást. Ez a hozzaállás ellentétben áll szüleik munkához való viszonyulásával.

„A szüleim, ők beleültek egy székbe, aztán majd kiszállnak valamikor, vagy kifordulnak a székből...ez generációs (dolog), mert változott a munkához való hozzáállása a generációnknak, nem ennyire kényelmesek, hogy itt a munkád, ha kilépsz, akkor börtönbe zárunk, ha nem lépsz ki, akkor kapsz fizetést, nem két opció van... Ezért lehet az, hogy ha valaki unalmasnak tartja a munkáját 3 év után, ha van rá lehetősége, akkor válthat." (Szilárd)

„A család nem tudta felvenni ezzel az egésszel a lépést, se anyukám, se apukám. Ők a rendszerváltás után nagyon rosszul kezdték érezni magukat és még rosszabbul lettek és már csak a nyugdíjazást várták." (Ádám)

Nem ragaszkodnak a munkahelyekhez, jó szakmai közegből is elmennek, ha úgy érzik, 
hogy már egy ideje nincsenek újabb kihívások. Újabb kihívás lehet új ügyfél, új koncepció, újabb technika, vagy új emberek.

„Szerintem a kreatívoknak jobb is, hogy ha 3-4 évente új munkahelyre kerülnek, új ügyfelekhez, új csapatba, mert ebbe nagyon hamar bele lehet fásulni... nagyon nagy a fluktuáció a szakmánkban, én is most egy kicsit elfáradtam, ebben a reklám szakmában szeretnék dolgozni, de nem biztos, hogy ebben az ügyfélkapcsolati vonalon... most más fele kacsingatok, produceri suliba járok jelenleg... azért vonz, mert annak a szakmának mindig van végterméke, itt ebben a pozíciómban nem mindig van termék akár egy fél éves munka után sem." (Csilla)

Ez a hozzáállás a vezetőség számára is nyilvánvaló, ezért támogatják cégen belül a kreatív munkakörökben való szerteágazó munkát, a feladatkörök tágítását, tehát ki-ki, érdeklődéséhez mérten belefolyhat a munkakörén kívül eső feladatkörökbe. Ha ez kevés, akkor jön a munkahelyváltás.

„Ha nem érzem, hogy itt már előre lehet lépni, nem érzem azt, hogy tanulok, ha nem változik körülöttem semmi, akkor lépek.(...) A kreatív igazgatónk nagyon mondja ezt, hogy nézzük meg, hogy itt tök jók a munkák, és hogy várjuk meg legalább ezt az elejét, amíg kipörgetjük ezeket a jó munkákat, és utána mehetünk." (Szilárd)

Nyitottságukat alátámasztja tanulási vágyuk is, törekvésük a tudásuk folyamatos bővítésére. Ez az önállóság és függetlenségi ambíció az, amivel az állandóan változó élethelyzetekhez alkalmazkodnak. S így nyitottságukhoz szükséges a szellemi függetlenség utáni vágy, amit viszont fokozott felelősségvállalás nélkül nem tudnak elérni.

\section{Önállóság}

Ez az önállóság gyakran inkább magárautaltságnak tűnik, mivel nincs egységes, jól használható séma a tudás és a tapasztalatok megszerzésére, hanem elébe kell menni a feladatoknak, információt nekik kell gyüjteni. Az itt megszólaltatott fiataloknak meg kell találniuk azokat a módokat, ahogy önállóságukat jól tudják hasznosítani.

„A marketinges, reklámos szakmában önállónak kell lenni, itt nincsen mese, sok megrendelésemet úgy vállaltam el, hogy minden fázisát nekem kellett megcsinálnom, pedig nem is értettem hozzá, ilyenkor internet, chat, haveroktól kérdezősködés, hogy figyelj, mit is kell ezzel csinálni, tehát magamnak kellett megoldanom, hogy kivitelezhessem a munkát. (...)

Volt már olyan is, hogy az egyik haverom, aki tudta, hogy mikkel foglalkozom felhívott szombaton, hogy kell az egyik projektjéhez, egy komoly plakát terv, szórólap elkészítése, fotózás meg miegymás, mindez persze hétfőre. Az komoly volt, rögtön neki is álltam, és meg lett, össze tudtam annyira magamat és a gondolataimat rántani, hogy kész lett. Az jó volt, élveztem is, nagyon gyorsan bele tudom élni magam dolgokba...” (Gergő)

A fiatal kreatív munkatársak az ilyesfajta önállóságból fakadóan más, a hierarchikustól eltérő viszonyt alakítanak ki a vezetősséggel.

„Amikor az előző főnököm elment, akkor egyedül maradtam, és én voltam az ember, akihez a többiek fordultak. (...) Akkor már abszolút benne voltam a szerepben, értettem már a reklámhoz, tudtam a technikai hátterét. Kaptam akkor is egy főnököt, de ő nem értett a technikai oldal részéhez. Ő sokkal nagyobb mértékben támaszkodott rám, mint 
amennyire az előző, és ekkor egy viszonylag nagy önállóságot kaptam a divízióban. (...) Az nem baj, hogyha van kontroll, nem is kontroll, inkább valaki, aki kívülről nézi a munkát, nem az lényeg, hogy folyamatosan megmondják, hogy mit csináljak, hanem, hogy legyen egy külső szemlélö, aki nem folyik bele a részletekbe. És aztán így nagyobb lett a felelősség, és ez tetszett...” (Szilárd)

A fönök ebben az esetben egy másik nézőpontot képvisel, de nem az utasításokon, hanem az együttmüködésen van a hangsúly, és ez a partneri viszony lazítja a munkalégkört. Az együttműködés a kreatív csapaton belül kulcsfontosságú, $s$ az, hogy ez milyen pontok mentén jelenik meg, az alábbiakban derül ki.

\section{Csapatmunka}

A megfelelő csapatmunka érdekében, a személyek közötti viszonyoknak túl kell mutatniuk a munkahelyi, szakmai ismeretségen.

„Amikor odakerültem a céghez, nagyon hamar rájöttem, hogy kurva jófej emberek vannak ott. Imádtam ott lenni, együtt mentünk el, hétvégén kirándulni, meg voltak közös programok, állandó kocsmázás, meg buli együtt, nagyon jó volt. Szerintem nagyon fontos az ilyen közös társasági élet a munkán kívül is a munkatársakkal. (...) Igazából lehet felülről szervezni csapatépítőt, de ha alapból nem jönnek ki jól az emberek, akkor nem müködhet." ( Szilárd)

„Mi sülve-fóve együtt vagyunk... ehhez a szakmához tartozik egy ilyen laza konverz cipős életforma, minden este mással találkozunk, megyünk menőzni... sokszor nem is itt bent dolgozunk, hanem mondjuk kimegyünk a Duna partra sétálni és ott jönnek az ötletek, de nagyon egymásra vagyunk utalva a csoport párommal, szimbiózisban vagyunk... azokkal a legjobb együtt dolgozni, akik kicsit elvontabbak, akikkel egy hullámhosszon vagy, inspiráljuk egymást...” (Eszter)

„Fontos, hogy akikkel közvetlenül együtt dolgozol, azokkal jóba legyél, most lehet, hogy szakmailag nem értesz velük egyet, meg vannak szakmai viták, de akkor is fontos az, hogy egy-egy ilyen kiabálás után, egy-egy vita után, amikor mindenki feszült, akkor tudjál úgy hozzászólni, hogy tökre nem veszem a szívemre, hogy mit kiabáltunk egymásnak az előbb, mert ez egy szakmai vita volt, (...) hogy ez vagy az volt otthon, kicsit összejött, de a helyén kell tudni kezelni, hogy ez miért volt...” (Szilárd)

A mindennapi munkastílusuk is a csapatmunkára ösztönzi őket, így hamar ki is derül, hogy ki illik kihez, s a jó párosok mennyire befolyásolják a kreatív alkotások minőségét, $s$ vele együtt a csapat mindennapi életét.

„Úgy dolgozunk a reklámügynökségnél, hogy a kreatív csapatban párok vannak, egy szövegíró, meg egy art direktor, és én összekerültem egy olyan szövegíróval, akit így emberileg nagyon szerettem, (...) tök jóban voltunk, de valahogy nem tudtunk együtt dolgozni. Ez ilyen kémia. Amikor gondolkodni meg alkotni kell együtt, akkor egyszerüen nem ment. Az ment, amikor ő is félrevonult, meg én is félrevonultam, csak ez így nem annyira hatékony. (...) Viszont akkor egy olyan kreatív igazgatónk volt, aki ezt így tök jól észrevette, és átvariálta a csoportokat. (...) Ez a fajta páros munka itt volt először, ami szerintem tök hatékony, ha sikerül jó párt találni." (Szilárd) 
Függetlenül attól, hogy sikerül-e jó párt találni, a jó párok közös munkája általában nem hosszú életü.

„Mondtam vissza állásajánlatot, mert engem hívtak a páromat nem tudták volna felvenni, de mi csak együtt mennénk át. (...) Most még fenntartanám, de lehet, hogy egy év múlva már nem. (...) Azért mondom, hogy 1-2 év, mert ezt is meg kell változtatni, ahhoz, hogy legyen új inger, tehát ahhoz szükség van erre. És tök jól dolgozunk együtt, de ha már nem fogok tudni mit tanulni, vagy megrekedek egy szinten, (...) akkor fogok lépni." (Szilárd)

A mindennapi csapatmunkában viszont egyesek nem nagyon motiváltak, ami igen terhes tud lenni egy olyan közeg számára, ahol a szakma iránti elkötelezettség igen fontos.

„Sokan azért melegedni járnak be, és pár embert noszogatni kell, hogy arrébb tegyenek egy füszálat is, és ezzel csak egymással tolunk ki, egymás dolgát nehezítjük meg... sokan nem veszik fel a tempót, a saját kis felszínességükkel kezelik a dolgokat, és nincsen bennük meg az a lojalitás, hogy átlássák, hogy ezzel alattam vágják csak a fát...” (Csilla)

Ezért fontos a csapat és a vezetőség számára, hogy ki milyen szakmai háttérrel lesz kreatív munkatárs.

\section{Szakmai tapasztalat}

Mivel általában, de Magyarországon különösen fiatal a reklámszakma, és a vizuális terület egyes részeit leszámítva nincsen külön képzési rendszer egy „kreatívosnak”, egészen eltéro közegből kerülnek össze a csoport tagjai. Szövegíróknál jellemző a bölcsész végzettség, mint a magyar, az angol, a filozófia, a kommunikáció, mert ez elmondásuk szerint jó alapot ad, és megtanít ,gondolkodni”.

Legtöbbször maguk se tudták, hogy mit csinál például egy szövegíró, mikor jelentkeztek a munkakörbe.

„Annyit tudtam, hogy reklámot,... érdekelt, mert mindig ki kell találni valamit. Az elso munkahelyemen tanultam meg, hogy mit kell csinálni egy szövegírónak. (...) Korábban én nem írtam, nem voltam író ember, történeteket szívesen meghallgattam. Minél rövidebb annál jobb, meg a filmek érdekeltek, gondoltam itt biztosan lehet filmeket csinálni, aztán lehet, ráadásul jobb is, mert fél percben.” (Ádám)

„Arra gondoltam, a szövegírás nem is lehet olyan rossz, de akkor még fogalmam sem volt, hogy ez mit jelent... arra fókuszáltam, hogy mi az amit tudok csinálni, írni ugye tudok. Azt hittem, hogy filmeket kell ismerni, szövegeket kell írni, meg csomó inspiráció kell...kicsit ilyen egyetemista módon közelítettem meg a reklám szakmát...” (Eszter)

Vizuális munkakörbe, ilyesfajta képzés nélkül az informatikai irány mutatkozik járható útnak.

„Mindig art direktor akartam lenni, mert az egyrészt tök jól hangzik, másrészt, meg mindig azt mondták, hogy az art direktorok jól keresnek. (...) Nekem szerencsém volt, mert viszonylag fokozatos volt az eltolódás, tehát elkezdtem informatikát tanulni, programozás, weboldalak, webdizájn, design, art direkció, tehát hogy tök széles skálát bejártam. (...) A webdizájn, meg ez a megközelítése a dolgoknak, az nagyon más, mint a reklámos megközelítés. Még a webdizájner alapvetően egy funkcionális kezelőfelületet készít el, 
addig a reklám egy kommunikációs eszköz, (...) nehezen tanultam meg, mert én ezt sohasem tanultam korábban." (Szilárd)

A reklámszakmába való bekerülés után, az addig összegyüjtött munkákat tartalmazó portfólió az, ami meghatározza a kreatívos helyét és az előrehaladást lehetővé teszi a szakmában.

„Ebben a szakmában a portfólió a legnagyobb kincs, tehát egy jó portfóliót összeállítasz, akkor kapkodnak érted, és nagyon számít az, hogy mit vernek ki belőlem. Tehát ha látom, hogy sikerült egy olyan munkát csinálni, ami megint mehet a portfólióba, akkor az nagyon értékes a jövőre nézve, (...) de nem mindegy, hogy milyen ügyfélnek dolgozol.” (Szilárd)

A portfólió mellett a különböző reklámos fesztiválok díjainak elnyerése is fontos.

„Szövegíróként nem lehet tovább lépni egy cégen belül, nincsenek perspektívák, túl fiatalnak tartanak minket, nincsen túl nagy szakmai tapasztalatunk szerintük... Díjakat kell nyerni, például az aranypengét, ezzel előbbre lehet jutni... Ebben a szakmában mennek az emberek egyik cégtől a másikba, mint a pingpong labda, csak így lehet érvényesülni." (Eszter)

A „vándormadár” életmód ellenére, a szakmához való ragaszkodás, vagy elkötelezettség igen erős, csakhogy ez nem kötődik a munkahelyhez, és az egyes ügynökségekhez.

„Abban 27 évesen már biztos vagyok, hogy jók a képességeim, és ki szeretnék tartani emellett a szakma mellett... De ebben a szakmában gyülnek a lelkileg kisfiúk, mert itt nem kell felnőni, nevetgélünk, kreatívoskodunk, este elmegyünk inni. (...) Vannak köztünk olyanok akik teljesen beleszarnak az egész életbe, hogy lesz-e lakása, lesz-e barátnője, lesz-e pénze mondjuk pár év múlva, ez nagyon tipikus ebben a szakmában...ismerek olyan írókat, akik nem akarnak dolgozni sem, csak néha írogatni, retteg attól a naptól, amikor már a szülei megvonják az apanázst, kikerülnek az egyetemről, és muszáj lesz bulvár szakmát, hétköznapi munkát is elvállalniuk, undorodnak ettől az egész világtól... én könnyen beilleszkedtem ebbe a világba..." (Eszter)

Eme ragaszkodás mibenlétének van egy fontos vonatkozása, amelyet a következőkben, a távlatokban való gondolkodás hívószavunknál jobban megvilágítunk.

\section{Távlatokban való gondolkodás}

A távolabbi jövőről csak homályos elképzeléseik vannak. Gyakran számukra sem világos mi lesz velük 5-10 év múlva, de legtöbbször addigra már nem tudják elképzelni magukat a reklámszakmában.

„Nem feltétlenül szeretnék családot, gyerekeket, én nem szeretnék senkit megszívatni, nem is értem, hogy egyesek hogyan tudnak, hogyan képesek gyereket vállalni, a házasság sem fontos számomra, viszont szeretnék sikeres lenni... az életszínvonal az első helyen áll, hogy minden hónapban utazhassak, ne legyen gond, hogy meg akarok venni valami drága ruhát... Magyarországon divat sincs, ahogy reklám sincsen ezért szeretnék kimenni külföldre, Angliába, persze ehhez kell az összeköttetés. Hobbi szerűen minden két hétben 10 külföldi céghez beadom a portfóliómat, nagyon ki akarok jutni, ezek a távlati céljaim... Az a siker számomra, hogy az agyammal dolgozzak, hogy alkothassak valamit, ez nekem fontos, ezt szeretném a jövőben csinálni. (...) Szeretnék ebben a szakmában egy szabad- 
úszó céget csinálni, persze anyagilag nem tudnám vállalni érte a felelősséget, de ha valaki megcsinálná, ahhoz szívesen csatlakoznék, ezt szeretném csinálni. A szövegírást szeretem, amit szeretek abban kitartó vagyok, szorgalmas..." (Eszter)

„Voltam kint a csángóknál egy fotós projekt során, majdnem ott is maradtam tanítóként. Körbe jártam a környéket, az ott élő emberek között éltem jó pár hétig... nagyon megfogott az az egész milio,, az a puritánság, összetartás, annyira más ott minden, imádtam azt az egészet. Sírtam, amikor vissza kellet jönnöm... ezért vagyok most válságban lelkileg, mert nincs olyan nap, hogy ne jutna eszembe, hogy nekem ott kellene lennem, tanítanom, a kreativitásomat felhasználva segítenem őket, ügyes módon szerezni pénzt, hogy legyen ott kint magyar suli, sok minden eszembe jutott, hogy hogyan lehetne pénzt szerezni ehhez az egész projekthez, akár állami szintig felmenni... nincsen nekik ott lent, hogy mondjam marketingjük, ez valami fentebb cél számomra, de az igazat bevallva egy kicsit beszartam, hogy mi lenne ennek a vége, meddig lehetne ezt csinálni, visszajönnék és megint úgy érezném, hogy valamiről lecsúsztam... a családban nagyon sok kalandor volt, akik megszopta rendesen, és ebben én nem szeretnék belemenni, nagyon sok ismerősömnek már lakása van, gyereke, ezek azért számomra is valamennyire fontosak..." (Gergö)

Sokuk egészen máshol képzeli magát pár év múlva.

„Ezt akarom csinálni, de ezt se lehet a végtelenségig csinálni, talán saját vállalkozást, (...) ha kitalálok valami jót, és szeretnék kitalálni valamit. (...) Valamit letenni az asztalra, hogy ne érezzem azt, hogy rá vagyok utalva másra ilyen szempontból.” (Ádám)

„Én kicsit ilyen előrelátóbbnak látom magam ilyen szempontból, most kevésbé érdekel a pénz, de jobban érdekel a munka. (...) Valahogy úgy szeretnék, hogyha két év múlva mennék valahova, akkor magasabb pozícióba, tehát ez annyit jelent, hogy több pénz, és annyit, hogy több a tapasztalatom. (...) Most igazából élvezem ezt a környezet, tulajdonképpen jó ez a mindenes kreatív dolog, csinálunk filmet is, csinálunk weboldalakat is, de igazából teljes koncepciókat dolgozunk ki." (Szilárd)

Mintha ezt a szakmát csak a fiatal felnőttkoruk részének gondolnák, amiből egyszer majd tovább kell vándorolniuk valami egészen más felé. Talán érzik, hogy az effajta ötleteikből egy idő után kimerülhetnek, kiéghet a most jelen lévő mindennapi hajtóerejük, motivációjuk. Vagy egy idő után a nagy kihívás igénye viszi egy teljesen új területre őket.

„Majd meglátjuk, én az gondoltam, hogyha kilépek a szakmából olyan 40 évesen, akkor valamilyen kis privát biznisz, lehet, hogy saját ügynökség." (Szilárd)

„Ha ebben a munkában maradok, akkor nyilván valami vezető dolog felé akarok elmenni, csak most nem érzem magamban azt az erőt, hogy 5 évnél tovább én ezt még csináljam. Sőt az már rengeteg, még 5 éve sem vagyok a szakmában, és már most azt mondom, hogy kissé reménytelennek látom a helyzetet." (Csilla)

Ez a munka nem csak a pénzről szól, ha sok lenne belőle, és nem kellene dolgozni...

„... akkor is olvasnék szakmai sajtót, meg akkor is érdekelne, hogy hova megy a világ. És igazából ez a szakma kicsit erről is szól, hogy követni a világot. Ez egy alapvető kíváncsiság, ez nem egy munka, nem feladat, egy elvégzendő dolog, amit meg kell csinálni, mert kell, hanem érdekel, hogy mi motiválja az embereket, hogy mi befolyásolja a döntéseiket, és hogyan lesz egy információból egy vírus szerủ terjedés, tehát ezek olyan dolgok, amik mindig érdekesek lesznek számomra. Ha gazdag leszek, lottót nyerek, akkor lehet, hogy 
nem feltétlenül az lesz a szempont, hogy pénzt keressek vele, hanem hogy ezt a kíváncsiságomat kielégítsem, és hogyha ha kihívást szeretnék, szerintem kihívás céget csinálni. Olyan, mint egy nagy társasjáték." (Szilárd)

\section{A motivációs levélen túl...}

Összefoglalásként elmondhatjuk, hogy ezen 80-as években született kreatív szakmában dolgozó fiatalok változáshoz való viszonyulása nagyban különbözik a szüleik generációjáétól. Ezen fiatalok munkához való viszonyulása egy lehetséges válasz a lineáris karrierpálya és az ehhez kapcsolódó életvitel hiányára, mivel sok esetben szüleik generációja ebben nem szolgál követhető mintával.

Véleményünk szerint a „kreatívosok” által képviselt munka-attitűd túlmutat a reklámszakmán, mivel a jelen kor fiatalságának egy igen jellemző életvitel- és munkafelfogása tükröződik benne.

A kreativitásból táplálkozó reklámszakmában fokozottan jelenik meg az állandó változás igénye. Az állandó változás és a kreativitás kölcsönhatásban állnak egymással. Ök ezek között élnek nagyrészt tudatosan vállalva az ebből fakadó bizonytalanságokat. Az újabb és újabb kihívások keresése vándormadarakká teszi őket. Amíg a rendszeres munkahelyváltás néhány évtizede negatív töltésű volt, mert a munka iránti elkötelezettség hiányát jelölte, addig ebben a szakmában ez magától értetődő, sőt elengedhetetlen az érvényesüléshez. Ez magára utaltsággal jár, és jó önmenedzselést követel az egyéntől, ha folytonos előrelépésre törekszik a szakmában. Csapatmunka ide vagy oda, a megkérdezettek életében az emberek ugyanúgy cserélődnek, mint a munkahelyek, kellenek az új látásmódok, az új gondolatok, ez persze nem a személyes szimpátiákra vonatkozik, hanem a szakmára. Ebben a helyzetben az ember csak egy dolgot tehet, jobban bízik a képességeiben, mint a tapasztalataiban, folyton tanul, nyitott az új lehetőségekre, de nem tud távlatokban gondolkodni, mert az csak elbizonytalanítja, hisz rengeteg a lehetőség. A legfontosabb, hogy a változásokhoz való alkalmazkodóképességét fejleszti. Tehát kreatív?

Ez egy alternatíva a világ követésére. 


\section{Antal Nikolett:}

\section{Lemoshatatlan festékek - nem gyógyuló sebek}

A kortárs művészet poszttraumatikus jelenségei

A kortárs müvészet egyre gyakrabban tüzi ki célul, hogy egy olyan korszakkal foglalkozzon, amely számára bizonyos mértékig még mindig hozzáférhetetlen. E hozzáférhetetlenség nemcsak a tények objektív módon történő megismerésének lehetetlensége miatt áll fenn, nemcsak egyes dokumentumok titkosítása miatt, hanem azért is, mert ezek a korszakok olyan nyomokat hagytak, melyekről sok esetben nehéz beszélni. Az erre irányuló akarat azonban folyamatosan növekszik, amely növekedés nem kis mértékben köszönhető annak a generációnak, amely közvetlen módon nem élte meg e korszakok történéseit, gondolva itt elsősorban a Holocaust, valamint az államszocializmus időszakára s annak minden hozadékára.

A kortárs magyar és nemzetközi művészet - így a szépirodalom is - egyre erősebben törekszik arra, hogy szembenézzen és szembenézessen, hogy lásson és láttasson e korszakokat illetően: dolgozatom egy szűkebb keresztmetszetet próbál adni e törekvésekből többféle müvészeti ágat érintve magyar és nemzetközi szinten is. Célom az, hogy a szakirodalomra és személyes tapasztalatokra támaszkodva bemutassam, az e korszakokra irányuló munkák és kutatások egytől egyig egyetlen célt szolgálnak: a túllépést, az újrakezdést, amely kizárólag a múlt feldolgozásával és belsővé tételével, integrálásával lehetséges.

A teljesség igénye nélkül közérthető módon törekszem egyfajta elméleti alapvetésre, a trauma és poszttrauma fogalmainak magyarázatára, a poszttraumatikus jelenségek erős jelenvalóságának s e jelenvalóság okainak tisztázására. Mindezek azonban azt a célt szolgálják, hogy a tárgyalt magyar és nemzetközi alkotások valódi hátterét tárják fel.

„Igazuk volt azoknak, akik fellázadtak a rendszer ellen. Pereket kohol, ártatlanokat ítél halálra, kínoz meg, küld büntetőlágerbe, telepít ki otthonából ez a rendszer, amely származás szerint ugyanúgy megkülönböztet, mint az előző, csak nem vérségi, hanem osztályalapon. Rosszul ítélték meg ezt a rendszert a jámbor idealisták, mint ő is. Vérrel, verítékkel, önzetlenül, áldozatosan dolgoztak érte, pedig gyilkos rendszer ez is. Ö maga kék cédulával szavazott, teherautón szállították őket, és új meg új körzetekben a kommunistákra szavaztak törvénytelenül, a nép ellenében; más büne nem volt. A nép akkor sem tudta, kire és mire szavaz, és most sem tudja. A falusiak vasvillával és szentképekkel fogadták, amikor a háború után agitálni ment, ezer év sötétségét hordták a szemükben. De attól még ez a rendszer gyilkos rendszer. A gyilkolást folytatják most is ugyanúgy és ugyan- 
olyanok: pereket koholva, megfélemlítéssel. Igaza van Szász Lalinak, ezek is fasiszták, ha vörösök is."' (Kiemelés tőlem.) Spiró György regényének (anti)hőse, Fátray Gyula egyik nap az összeesküvők közt olvassa vezetéknevét, itt kezdődik többnapos tébolya, amelyből aztán a deus ex machinának köszönhetően, csodával határos módon sikerül kikerülnie. Belső monológját - igazi szarkazmus ez - a május 1-jei felvonulás előtt halljuk, amelyen ő is részt vesz, a más büne nem volt kifejezés többek között ezen a ponton is a rendszer húsbavágó igazságává, jelenségévé válik. Azaz bün és bủntelenség paradox együttes létezésének bizonyítékává egy olyan korban, amelyben a naivitás, a tudatlanság és a szembenézésre való képtelenség a politikailag korrekt viselkedés velejárói lesznek, $s$ amelyben a 'legvidámabb barakk' rothadó büzét szándékosan senki sem érzi meg. Fátray Gyula hajlandó tovább élni egy olyan világban, amely egyszer meghurcolja, másszor kiemeli ugyanazért a viselkedésért, felesége képtelen észrevenni a veszélyt abban, amikor fizetésemeléssel és munkahelye megváltoztatásával besúgásra veszik rá, ettől a mellékes tényezőtől ugyanis hajlandó eltekinteni; s be kell látnunk, túlzottan összetett folyamatokról van szó ahhoz, hogy kizárólag a moralitás mentén haladva mondjunk ítéletet a felnövekvő generációnak. Hiszen ezek a szereplők is egytől egyig tettesek, de nem a kollektív bünösségről van itt szó, hanem arról, hogy bizonyos esetekben tettes és áldozat egy személyben létezik, s sem az áldozat nem ismeri fel áldozattá, sem a tettes tettessé válását. Ehhez hozzátartozik továbbá az is, hogy nem konkrétan a rémtettek végrehajtóinak tettes-traumájáról van szó, hanem a nézők - egy afféle „bystander”2 pozícióból megszólaló - traumájáról. Gyakran fölmerül ugyanis a kérdés, hogyan lehet megértetni, mit jelent 1956 emléke (de mindenképp ide sorolandó a Holocaust is). Hogy hogyan jelenhetett meg 1989-ben a Népszabadság ünnepi száma Nagy Imre és mártírtársai újratemetéséről, amely név szerint tette közzé a kivégzettek listáját, majd pár oldallal később szívélyesen emlékezett meg Kádár Jánosról?3 Hogy hogyan lehet tettes és áldozat egy helyen, egyazon orgánumban? Hogy hogyan lehet mai napig az, hogy az 1956-ra való emlékezés megfér egy helyen a kádári nosztalgiával? A kérdések persze a végtelenségig folytathatók, azonban egyetlen ponton mégis összeérnek: a 80-as évek generációját (a későbbiekről nem is beszélve) a korábbiaktól elválasztó szemléletbeli különbségben, mely éppen a múlt megértésének akarásában rejlik. Nem lehet ugyanis véletlen, hogy a 21. század művészete egyre nagyobb erővel és energiával közelít a 20. századhoz és szörnyűségeihez, s a befogadókat egyre nagyobb megosztottság jellemzi.

Nekünk és a fent említett múlt megélőinek is van egy különös egzisztenciális tapasztalatunk: a trauma. A trauma, amely egyszeri és megismételhetetlen, amely soha nem hozzáférhető, nem magyarázható, s nagy, olykor összemberi léptékben jelentkezik. Az, amit később megértünk belőle, amit a gyerekek, unokák, dédunokák vagy a kívülálló második és harmadik generáció megismer, a poszttraumatikus tapasztalat. Megosztó kérdés, hogyan lehet olyan traumákról beszélni, alkotásokban megjeleníteni, amelyekről nincs

\footnotetext{
${ }^{1}$ SPIRÓ György, Tavaszi tárlat, Budapest, Magvető, 2010, 251-252.

${ }^{2}$ GIESEN, Bernhard, Das Tätertrauma der Deutschen, in: Tätertrauma: Nationale Erinnerungen im öffentliche Diskurs, Konstanz, UVK Verlagsgesellschaft GmbH, 11-53.

${ }^{3}$ Erre Viczián Zsófia egyik írása hívta fel a figyelmemet. VICZIÁN Zsófia, A nemzeti minimum és '56, in: http://www. komment.hu/tartalom/20101021-velemeny-keves-film-erteti-meg-a-kozepiskolasokkal-56-lenyeget.html. Népszabadság, 1989. június 17., 3-5. 1., 11. 1., Gyászszertartás a Hősök terén és a 301-es parcellában (a kivégzettek névsora, gyászbeszédek), Egy profi és sok amatőr szimultánja, Aczél György a pécsi értelmiségi klubban.
} 
semmiféle tapasztalatunk, nemcsak közvetlen nem, de még családtagok által közvetített sem. Hogyan lehet nem zsidóként beszélni a Holocaustról, s helytálló-e a kritikusok hitelességet megkérdőjelező álláspontja. Winfried Georg Sebald kortárs német író, aki több szövegében szólaltatja meg zsidó származású hőseit, de különösen izgalmas Austerlitz nevü figurája (a hasonló címet viselö regényben ${ }^{4}$ ), aki csak életének egy bizonyos szakaszában jön rá arra, hogy zsidó, szülei elvesztek a koncentrációs táborokban, s eddig nevelőszülőknél élt, sőt, még a neve sem az, amit eddig annak hitt. Ami a szerkezetet alakítja, az emlékezés folyamata: Austerlitz kényszerü emlékezése önmagára, illetve emlékeztetése valamikori önmagára, akit éppen ő nem ismer. Az emlékek elmondása időben előre haladva az egyre régebbi múlt felé visznek; ám ezzel párhuzamos Sebald felbontja a hagyományos időkezelés lehetőségét. A múlt válik jelenné az emlékezés folyamatában, nemcsak a fényképek és archívumok segítségével, hanem a múlt kísérteteinek megelevenedésével is. Ennek legfőbb példája Austerlitz Theresienstadtban tett látogatása, ahol az emberek hiánya árulkodik valamikori ottlétükről: „...egy négyzetkilométeres beépített területen közel hatvanezer ember volt összezárva, és nem sokkal később, amikor ismét kint álltam az elhagyatott téren, egyszer csak a legélesebben úgy tünt, mintha nem is vitték volna el őket, hanem élnének, úgy, mint rég, összezsúfolódva a házakban, az alagsorokban és a padlásokon, mintha szünös-szüntelen föl-le járkálnának a lépcsőkön, kitekintgetnének az ablakokon, tömegével járkálnának az utakon és utcákon, sőt néma gyülekezetükkel kitöltenék még az egész, szemerkélő esőtől szürkére satírozott teret is a levegőben.” ${ }^{\circ} \mathrm{A}$ trauma-emlékezés kérdéskörén belül tökéletesen érzékelhetjük azt, hogy az erről való gondolkodás csakis egy széles kontinuum mentén képzelhető el. Ahogyan a kommunikatív és kulturális emlékezet összemosódása figyelhető meg Austerlitz élettörténetében, úgy egyéni és kollektív trauma, valamint biografikus és megalapozó emlékezés is ebbe a kategóriába tartoznak. A múlt szilárd pontjaira vonatkozó emlékezés, amely Jan Assmann megfogalmazásában már „az intézményesített mnemotechnika ügye”, olyanná válik, amelyen egyszerre osztozunk kortársainkkal is. A kollektivizálódott traumák - amilyen a Holocaust - mindig egyéni traumák összességei, ennek következtében nem lehet különbséget tenni egyértelműen a kettő között. Továbbá pedig az is elmondható az emlékek eme halmazáról, hogy társas interakciókban léteznek, annak köszönhetik fennmaradásukat, de ezzel párhuzamosan mégis tárgyiasított alakzatokkal működnek, amit mi sem bizonyít jobban, mint a Theresienstadtban Austerlitz által meglátogatott Gettómúzeum. Ezen a ponton kell kissé előreugranunk, hiszen azáltal, hogy a múlt bizonyos eseményeiről egy kanonizált és tanítandó álláspontot alakítunk ki nemcsak megkönnyítjük az ezekre való emlékezést, hanem egyben lehetetlenné is tesszük azt. Kérdéses tehát, hogy a felnövekvő generáció számára melyik út tủnik járhatóbbnak, hogy ez a paradox jelleg és döntéskényszer ne vezessen egyfajta dezidentifikációs folyamathoz. Sebald hősével párhuzamosan formálódik meg Art Spiegelman Artie nevü hőse egy képregény lapjain, aki fejébe veszi, hogy

${ }^{4}$ SEBALD, Winfried Georg, Austerlitz, C. Hanser, München, 2001., magyar kiadás: Blaschtik Éva ford., Európa Kiadó, Budapest, 2007.

SEBALD, W. G., i.m., 215.

${ }^{5}$ SEBALD, W. G., i.m., 215.

${ }^{6}$ ASSMANN, Jan, A kulturális emlékezet, Hidas Zoltán ford., Budapest, Atlantisz Könyvkiadó, 1999, 53.

${ }^{7}$ SPIEGELMAN, Art, Maus: a surviver's tale, I. My father Bleeds History, New York, 1986, II. and here my troubles began, New York, 1991; folytatásos közlés: Raw Magazin, 1973-1986, 1986-1991. 
képregényt ír családja elhurcolásáról, amelybe később anyja belehalt, testvére szintén, s a túlélő apát kéri, hogy emlékezzen és beszéljen. A képregény tulajdonképpen klasszikus másodgenerációs Holocaust-elbeszélés, annak a története, hogy a fiú hogyan szerzi meg és teszi sajátjává apja történetét. Ami a sokak által ismert információkon túl kapcsolódik ezen dolgozat témájához, az a mủfaj kérdése. Ugyanis e képregény esetében nemcsak a szó és kép egyesek által feltételezett rangbeli különbségére irányulnak a kérdésfelvetések, hanem arra is, hogy milyen a Holocaust viszonya a popularitással. Így lett a Maus képregény, azaz comic book, nem pedig grafikus regény vagy graphic novel, amely magában hordozza a regény szót, mint a magaskultúra jelölőjét.

A lengyel származású Artur Zmijewski $80064^{8}$ - a címadó szám az interjúalany (egy zsidó férfi) karjába vésett jel a koncentrációs táborból - címủ dokumentumfilmjében túllép az emlékeztetés beszéddel történő határain, a filmben ugyanis újratetoválják a már megkopott számsort (1. kép, 2. kép). Ahogyan a közelmúltban nagy felháborodást keltett, az I will survive zenéjére táncoló Holocaust-túlélö, aki az auschwitzi láger területén ünnepli életben maradását. Az eredmény azonban ugyanaz: emlékezni és az áldozatot emlékeztetni a múlt traumatikus eseményeire, $s$ felhívni rájuk azoknak is a figyelmét, akiknek esetleg semmilyen közük nem volt hozzájuk, valamint azokét is, akik mintegy blaszfémiaként tekintenek a Holocaust ilyen típusú megjelenítésére. A kérdés csak az, hogy miért? Miért váltanak ki felháborodást az ilyen akciók? Miért érezzük olyasminek a múlt ezen szegmensét, amiről csak suttogva beszélhetünk, amiből „nem illik tréfát űzni”? A válasz talán az, hogy ezzel a tiszteletadással el is távolítjuk magunktól még csak a szembenézés lehetőségét is, nem az áldozatokat, hanem önmagunkat megóvva. Még hozzáférhetetlenebbé téve a nagy traumákat, mint amilyenek azok valójában. Egy híres kultúratudós és pszichoanalitikus páros, Shoshana Felman és Dori Laub megjelentetett egy Testimony címü könyvet, amely az áldozatok tanúságtételét hordozza. Később leírják többek között azokat a tapasztalataikat, melyeket hallgatóikon vettek észre, miután szembesítették őket bizonyos traumatikus eseményekkel, a túlélők vagy családtagok elbeszélésivel. A diákok reakciója egy újra átélt trauma volt, immár a trauma traumája, amely generációs és családi kapcsolattól függetlenül jelentkezett. Ez lehet a poszttraumatikus tapasztalat alapja: képes vagyok újra átélni, a magamévá tenni a családtagjaim életében történt traumákat, ugyanakkor tovább tudok élni velük, ám ezen túllépve mindenféle kapcsolat nélkül tudom megérteni és integrálni a mások traumáit, immáron magamban hordozva, ami szembenézésre, beszédre vagy alkotásra késztet.

A hagyományos törekvések és múzeumi terek (egyrészt egyre kisebb népszerüségnek örvendenek) valamelyest ki is irtják, meg is szüntetik az emlékeket, hiszen azáltal, hogy megjelenítik a tárgyakat, meg is fosztják őket valódi kontextusuktól, így csak valaminek a hiányát és távollétét idézik fel. Így válnak a múzeumban kiállítottak még távolabbivá és még kevésbé hozzáférhetővé. Ismeretes, hogy Hitler a világháború végével egy zsidó múzeumot akart berendezni, ezért őriztetett meg sokat az elkobzott tárgyakból. Az elpusztított emberek ugyanis az emlékük révén továbbéltek, ám újra történő tárgyiasításuk révén, melyben egy múzeum sorszámozott darabjaivá válnak, még az emlékezetből is ki lehetett 
volna törölni őket. Ydessa Hendeles Társak című installációja először egy olyan térbe enged, ahol fényképeket láthatunk, melyek résztvevői egytől egyig egy játékmackóval szerepelnek, külön csoportot alkotva ezen belül is a Holocaust-áldozatok (3. kép, 4. kép, 5. kép). A következő terem az azt megelőző zsúfoltságához képest azonban meglehetősen egyszerü és üres, egy nekünk háttal térdeplő Hitler-arcú gyerektestű viaszbábuval a középpontban (6. kép). Sokan sokfélét mondanak erről a kompozícióról, ám fölmerül a kérdés, hogy a fentiek értelmében szóba jöhet-e a hitleri náci pusztítás eltávolítása. Hogy lehet-e ez egyszerre szembenézés és leszámolás a múlt azon szegmensével, melyben a legalapvetőbb emberi értékek és normák kérdőjeleződtek meg? $S$ a teremben, a térdeplő alakkal szemközti üres, fehér fal jelentheti-e azt az emlékekkel és traumákkal zsúfolt, ám mégis a továbblépés lehetőségével felruházott életet, amely oly fontos lenne a fiatalabb generációk számára? Ha egy szubjektum más szubjektumokból objektumokat csinál, tulajdonképpen nem történik más, mint hogy öntudatlanul, de önmaga szubjektum-pozícióját is megkérdőjelezi, s Hendeles munkája ennek is a bizonyítékává válik.

Összefoglalva a megjelenő fogalmakat: az alcím két olyan szót tartalmaz, amely némi magyarázatra szorul. Kortársnak tekintem, azt, ami a posztmodern óta létezik és keletkezik. „Posztmodernitás alatt az ún. nyugati társadalmak legújabb történelmi korszakát értjük, melynek során az 1950-es évekig jellemző modernitáshoz képest új jegyek jelennek meg. Az ún. posztindusztriális társadalmakról van szó (Daniel Bell), melyek az iparosodás utáni fázisokban a multinacionális nagyvállalatoktól irányított fogyasztói, illetve információs-tömegkommunikációs társadalmak lesznek. A homogén nemzetet a heterogén és multikulturális nemzet váltja fel, azaz az etnikailag és kulturálisan egyközpontú társadalom többközpontúvá és többszörözött kulturalitásúvá válik. A posztmodernitás társadalma a tömegtársadalom, melyben az egyén a tömegkultúra fogyasztójává, $s$ egyúttal a fogyasztott tömegkultúra tömegtermékévé konformizálódik, illetve manipulálódik.." ${ }^{10}$ Mindez azért fontos, mert e korban jelent meg az a művészet és beszédmód, melyre alapvetően nyomta rá a bélyegét a Holocaust, ahogyan az amerikai pszichében ott volt Hirosima vagy napjainkban szeptember 11. tapasztalata, Kelet-Európában a Szovjetunió befolyásának időszaka. Ezen korszakokat egyetlen dolog köti össze, kétségessé válnak a létezés addig magától értetődőnek tartott formái. A traumákat ezek az emlékek táplálják, a szót azonban túlzottan sok értelemben és helyzetben használjuk, ennek oka, hogy olyan vándorfogalomról van szó, amely a 20. század elején Freud hatására került be a pszichoanalízis szókincsébe a baleseti sebészetből, majd a 21. század elején került a kultúratudomány központi helyére egyesek szerint éppen a szeptember 11-i események hatására. A poszttrauma jelentheti a traumák utáni állapotot (ld. PTSD - Post-Traumatic Stress Disorder - poszttraumás stressz zavar), de Marianne Hirsch postmemory (utóemlékezet) fogalmával összekötve nemcsak azokra használhatjuk, akik családi kapcsolatban vannak a traumák elszenvedőivel, hanem azokra is, akiknek semmilyen ilyen típusú kapcsolatuk nincs, egyszerüen csak képesek sajátjukként tekinteni a problémákra és a traumák hatásaira, $s$ akár akaratuk ellenére bármikor felidézni a traumatikus emlékeket. „Az utóemlékezet fogalmát kultu-

${ }^{9}$ HENDELES, Ydessa, Társak, München, Haus der Kunst, 2003.

${ }^{10}$ BOLLOBÁS Enikő, Az amerikai irodalom története, Osiris Kiadó, Budapest, 2006, 644. 
rális vagy kollektív trauma túlélöi gyermekeinek a szüleik élményeihez való viszonyulására használom, azaz olyan élményekre, amelyekre úgy emlékeznek, mint a gyermekkorukat meghatározó történetekre, illetve képekre, amelyek azonban olyan erőteljesek, olyan monumentálisak, hogy saját jogon is emlékké formálódnak. (...) Az utóemlékezet azok élményeit jellemzi, akiknek felnőtté válását a születésük előtti történetek határozzák meg, s akiknek saját megkésett történeteit az előző generáció történetei kiszorítják. E történeteket olyan traumatikus események formálják, melyeket a későbbi generáció sem megérteni, sem reprodukálni nem tud. (...) Értelmezésem szerint az utóemlékezet nem identitás-pozíció, hanem az emlékezés tere, mely szélesebb értelemben is hozzáférhető, tehát nem csak az egyéni és személyes, hanem a kulturális és közéleti emlékezés, azonosulás és kivetítés útján. Itt a mások traumatikus élményeinek $-s$ így egyúttal emlékeinek - sajátként való adoptálásáról van szó, illetve olyan élményekről, melyeket akár magunk is átélhettünk volna, s melyeket ezért beleírunk saját élettörténetünkbe. (...) ....ahogy képes vagyok 'emlékezni' szüleim emlékeire, úgy arra is képes vagyok, hogy mások szenvedéseire is 'emlékezzek'." ${ }^{11}$ Ennek értelmében a következő dologgal kell leginkább foglalkoznunk: hogy megértsük saját élményeinket, ne vigyük tovább szorongásainkat és félelmeinket, hiszen addig nem leszünk képesek a saját életünkkel szembenézni.

A 80-as évek generációja sok ilyen poszttraumatikus tapasztalatnak van kitéve, $s$ amíg nem lesz képes valahogyan ezeket feldolgozni, megfelelő módon kezelni, addig sajnos csak álom marad a szemléletbeli különbségek megszüntetése, amely nem csak a generációs különbségekből adódik. Nézzük meg Kamen Stojanov Guys, this is not L.A, but a cool place too!!2 (7. kép) címü képét, mely a Mücsarnok Over the counter (A pult mögött-nem tükörfordítás!) nevet viselö kiállításának egyik darabja volt. A lerobbant panel tetején reklámhelyet árulnak ezzel a szlogennel, a háttérben kisebb-nagyobb panellakások tömkelegével. Ezen a képen tökéletesen látszik a valamikori tervgazdálkodás és a piacgazdaság, a szabad verseny időszakainak összeütközése. A kérdés pedig csak az, lehet-e az egyikben bármit is tenni, jövőt remélni, amíg a másik jelenünk szerves része. A példák sokfélék, több korszakból valók, ám mégis egytől egyig egy olyan problémát hangsúlyoznak, amely társadalmi szinten erősen jelen van és létezik. A továbblépés akarásának vagy a továbblépés szükségességének a problémája, hiszen a múlttal való szembenézés, valamint ezzel együtt az új felvállalása elkerülhetetlen eleme az autonóm identitás kialakításának. Fentebb már volt szó Shoshana Felman és Dori Laub Testimony (Tanúságtétel) címủ munkájáról.

A könyv leggyakrabban idézett története egy Menachem nevü zsidó fiúról szól, akit szülei ötévesen kicsempésztek egy gyüjtőtáborból, hátha sikerül a túlélés valahogyan. Anyja egy önmagáról készült diákkori fényképet adott a kezébe arra kérve a fiút, forduljon hozzá, ha szükségét érzi. Végül egy lengyel család fogadta be a gyereket, $s$ a szülők is túlélték a haláltábor megpróbáltatásait. Amikor megkeresték fiukat, az bácsinak és néninek szólította a lesoványodott, csíkos uniformist viselő szülőket, anyja cseppet sem hasonlított a képen látható nőhöz. A fiú nem tudott ezen túllépni, rémálmok és állandó szorongás

\footnotetext{
${ }^{11}$ HIRSCH, Marianne, Kivetített emlékezet - Holokauszt-fényképek a magán- és közösségi emlékezetben, Bán Zsófia ford., in: Enigma. Művészetelméleti folyóirat, 37-38, Holokauszt, 118-119

${ }^{12}$ STOJANOV, Kamen, Guys, this is not L.A. but is a cool place too!, 2010 ..
} 
kínozták, s amikor harmincöt évvel később a Testimony keletkezése közben elmondta történetét a szerzőknek, akkor nyílt alkalma elöször arra, hogy feldolgozza a múltját. Felman a fiú gondolatait idézi: „A következő dolog foglalkoztatott ebben a pillanatban: ha nem próbáljuk meg feldolgozni az érzelmeinket, ha nem értjük meg saját élményeinket, vajon mit teszünk gyermekeinkkel?... Átruházzuk szorongásainkat, félelmeinket és problémáinkat a következő generációra?... És itt nem csak az elveszett nemzedékről van szó... hanem ez esetben elveszett nemzedékekről beszélhetünk."13

A lényeg tehát egy valóságos perspektíva kialakítása, amely nem lehet egyenlő sem a végleges elvágyódással, sem egy olyan nézettel, amely nem vesz tudomást a fenti problémákról. Olyan alapokra van szükség, amelyekre biztonságosan lehet építeni, mely több tekintetben áll biztos társadalmi megegyezésen az elfogadás és tolerancia jegyében. „A jövo alakulása a múlt élményeivel behálózott jelen eredménye, ezért többnyire kiszámítható és tervezhető. E mellett a távlat mellett azonban létezik egy másik is: a jövő valóságának béklyóktól mentes víziója. A cél nem az, hogy létező tudást és tapasztalatot interpretáljunk, hanem, hogy kidolgozzunk egy lehetséges utópiát, és a létező realitás egy megvalósítható alternatíváján gondolkodjunk." ${ }^{14}$

\section{Felhasznált irodalom}

ASSMANN, Jan, A kulturális emlékezet, Hidas Zoltán ford., Budapest, Atlantisz Könyvkiadó, 1999.

BOLLOBÁS Enikő, Az amerikai irodalom története, Osiris Kiadó, Budapest, 2006.

FELMAN, Shoshana - LAUB, Dori, Testimony. Crises of Witnessing in Literature, Psychoanalysis and History, New York, 1992.

GIESEN, Bernhard, Das Tätertrauma der Deutschen, in: Tätertrauma: Nationale Erinnerungen im öffentliche Diskurs, Konstanz, UVK Verlagsgesellschaft GmbH.

HENDELES, Ydessa, Társak, München, Haus der Kunst, 2003.

HIRSCH, Marianne, Kivetített emlékezet - Holokauszt-fényképek a magán- és közösségi emlékezetben, Bán Zsófia ford., in: Enigma. Művészetelméleti folyóirat, 37-38, Holokauszt szám.

Népszabadság, 1989. június 17., 3-5., 11., Gyászszertartás a Hősök terén és a 301-es parcellában, Egy profi és sok amatőr szimultánja, Aczél György a pécsi értelmiségi klubban.

SEBALD, Winfried Georg, Austerlitz, C. Hanser, München, 2001., magyar kiadás: Blaschtik Éva ford., Európa Kiadó, Budapest, 2007.

SPIEGELMAN, Art, Maus: a surviver's tale, I. My father Bleeds History, New York, 1986, II. and here my troubles began, New York, 1991; folytatásos közlés: Raw Magazin, 1973-1986, 1986-1991.

SPIRÓ György, Tavaszi tárlat, Budapest, Magvető, 2010.

STOJANOV, Kamen, Guys, this is not L.A. but is a cool place too!, 2010.

www.reinungsgesellschaft.de/texte/textfuturepromise.htm, in: LÁZÁR Eszter - PETRÁNYI Zsolt, A pult mögött. A posztszocialista gazdaság jelenségei a kortárs művészetben, Múzeumi kiadvány, Bevezetö.

ZMIJEWSKI, Artur, 80064, 2004.

\footnotetext{
${ }^{13}$ FELMAN, Shoshana - LAUB, Dori, Testimony. Crises of Witnessing in Literature, Psychoanalysis and History, New York, 1992, 46, a részletet Bán Zsófia fordította.

${ }^{14}$ www.reinungsgesellschaft.de/texte/textfuturepromise.htm, in: LÁZÁR Eszter - PETRÁNYI Zsolt, A pult mögött. A posztszocialista gazdaság jelenségei a kortárs művészetben, Múzeumi kiadvány, Bevezető.
} 


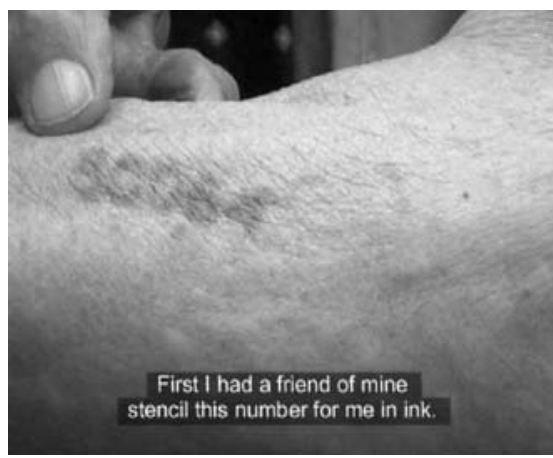

1. kép

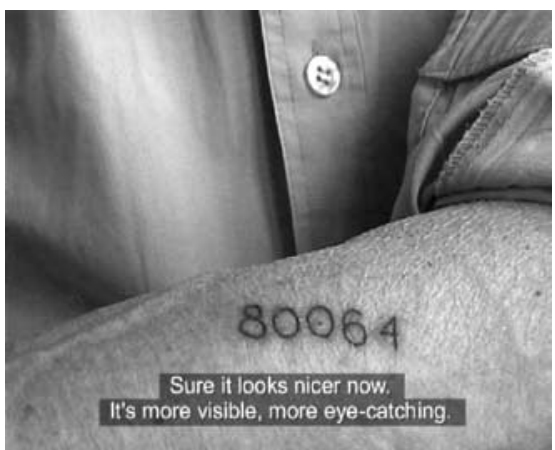

2. kép

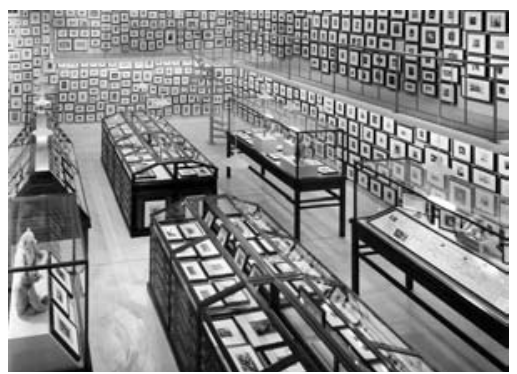

3. kép

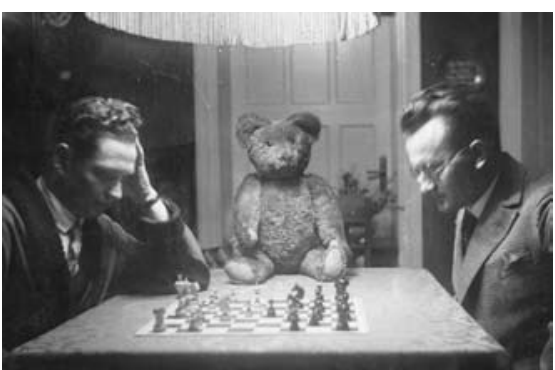

4. kép

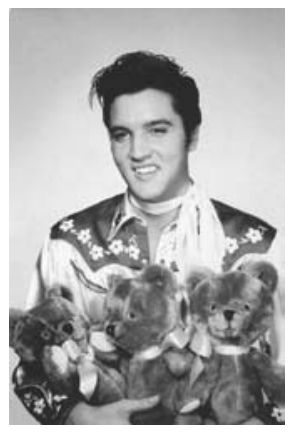

5. kép

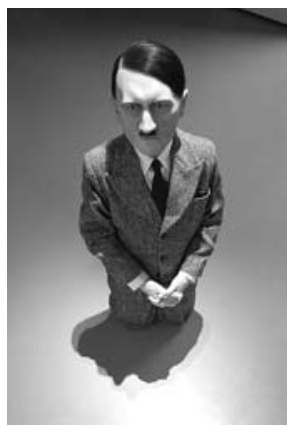

6. kép

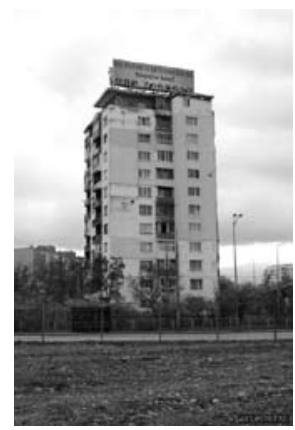

7. kép 


\section{A kötet szerzői}

Alpár Balázs (1982) a budapesti Zeneakadémián végzett zeneszerzés szakon, jelenleg a Bécsi Zeneakadémián folytat médiazeneszerzés PhD tanulmányokat. A Fugato Orchestra zeneszerzője és vezetője, számos játékfilm és előadás zeneszerzője, több zenekar billentyüse.

Langmár Péter (1986) a The American University of Paris, Global Communications szakán végzett. Internet, kulturális politika és menedzsment kutatással foglalkozott. Területe a részvételi és demokratikus kultúra. Jelenleg a párizsi Le Laboratoire művészeti és tudományos műhely munkatársa.

Tarr Ferenc (1986) filozófia-magyar-történelem szakon végzős hallgató az ELTÉ-n, illetve a PTE-n. Mintegy hét éve foglalkozik színházzal és annak pedagógiai lehetőségeivel. Több iskolaprogram lebonyolítója, jelenleg a Krétakör munkatársa.

\section{Alpár Balázs, Langmár Péter és Tarr Ferenc a Kontra Mühely alapitói.}

Antal Nikolett (1985) az ELTÉ-n végzett magyar nyelv és irodalom, valamint összehasonlító irodalomtudomány szakon, jelenleg az ELTE Irodalomtudományi Doktori Iskola Összehasonlító irodalomtudomány programjában vesz részt. Az OTDK-n szekciójában 4. helyezést ért el, valamint köztársasági ösztöndíjban is részesült.

Babócsai Zsuzsa (1986) a SZTE-n végzett szociológus. Több régiós kutatásban vett részt, területe elsősorban a művészet-szociológia és -pszichológia.

Berecz Dia (1986) az ME kulturális és vizuális antropológia szakán végzős hallgató, több kutatás résztvevője. A Goethe Intézet Kulturális Programszervezési Osztályán volt munkatárs.

Kocsis Andrea (1990) az ELTE BTK kommunikáció és médiatudomány szakos hallgatója, több online újság munkatársa. Területe elsősorban a kortárs populáris kultúra vizsgálata.

Korenyák Zsófia (1984) az ELTÉ-n végzett szociológus és szociális munkás. Számos társadalomtudományi kutatásban vett részt, valamint rendszeresen végez, elsősorban gyerekekkel kapcsolatos önkéntes munkát. A Széchenyi István Társadalomtudományi Szakkollégium tagja.

Laposa Richárd (1987) a PPKE szociológia, valamint európai és nemzetközi igazgatás MA szakos hallgatója, korábban ugyanitt szociológia szakon BA diplomát szerzett.

László Johanna (1983) az ELTÉ-n végzett szociális munkásként, ahol jelenleg a Szociológia Doktori Iskola Szociálpolitika programjában folytat kutatásokat. Eddigi munkái, kutatásai elsősorban az ifúságsegítés témakörébe tartoztak. 2009-ben az OTDK-án szekciójában első helyezést és különdíjat ért el, valamint köztársasági ösztöndíjban részesült. 
Molnár Zsófia (1982) az ÁVF-en végzett nemzetközi kapcsolatok szakreferensként, külkapcsolatok szakirányon. Jelenleg az ME kulturális és vizuális antropológia szakán végzős hallgató.

Papp Gergely (1985) az ME kulturális és vizuális antropológia szakán végzős hallgató, valamint az ELTE TTK-n geográfus hallgató. Rendszeresen végez animátori feladatokat különböző alapítványoknál és közhasznú szervezeteknél.

Pataki Teréz (1985) az ELTÉ-n végzett szociológus. Ösztöndíjasként tanult Párizsban, kutatóként és önkéntesként dolgozik. Többek között a színház és a társadalomtudományok kapcsolódását kereső Lakmusz Csoport tagja.

Schneider Géza (1987) a PPKE-n végzett szociológia szakon, diplomakutatását a budapesti agglomerációs ingázásból írta.

Stalzer Tamara (1989) az ELTÉ-n hallgat szociológiát, ezt megelőzően egy évig tanult konduktorként a Pető Intézetben.

Szabó Anita (1989) az ELTÉ-n hallgat társadalmi tanulmányokat, a Mathias Corvinus Szakkollégium tagja, ahol a modern kori történelem, Közép-Európa szakirányt választotta. 



\section{Kontra Múhely \\ A 80-AS GENERÁCIÓ}

A Kontra Múhely 2009 tavaszán alakult meg azzal a céllal, hogy kapcsolatot teremtsen fiatal társadalomtudósok és művészek között. Célunk egy olyan szellemi közösség kialakítása, ahol fiatal művészek és tudósok együttműködése során kortárs, alapvetően régiós társadalmi problémák és kérdések közös feldolgozására kerül sor.

Ennek szellemében tartottuk meg 2010 októberében három napos konferenciánkat a SíN Kulturális Központban, ahol összesen tizenegy fiatal társadalomtudós tartott előadást. Jelen esszékötet ennek a konferenciának az írásos változata, melyet 2011 januárjában adtunk ki és mutattunk be egy, a témát feldolgozó összmúvészeti est keretein belül. Jelen kiadvány nem szigorúan vett kutatások gyűjteménye, sokkal inkább egy, az alaposság igényével készült esszékötet, tényeken, vizsgálódásokon alapuló körkép arról, mit gondol ez a generáció saját magáról. Fontosnak tartjuk ugyanis, hogy korosztályunk mind a társadalomtudományok, mind az alkotótevékenység szempontjából reflektiven dolgozza fel önmaga, azaz a 80-as generáció kérdéseit és problémáit. Mert hisszük, hogy a mindezek megoldásához vezető út első lépése a negatív jelenségek realizálása, melyet reményeink szerint követhet majd egy új szellemiségben zajló aktív, cselekvő időszak is, mely a nyitottság és a párbeszéd elvén alapszik. 